\title{
Self-Assembly of Multinuclear Sandwich Silver(I) Complexes by Cooperation of Hexakis(azaheteroaryl)benzene Ligands, Argentophilic Interactions, and Fluoride Inclusion
}

Miha Drev, Uroš Grošelj, Drago Kočar, Franc Perdih, Jurij Svete, Bogdan Štefane, and Franc Požgan*

Faculty of Chemistry and Chemical Technology, University of Ljubljana, Večna pot 113, SI-1000 Ljubljana (Slovenia) 


\section{Table of Contents}

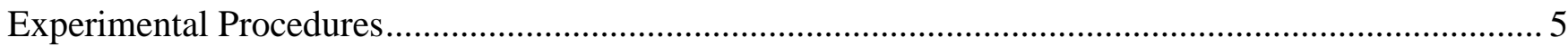

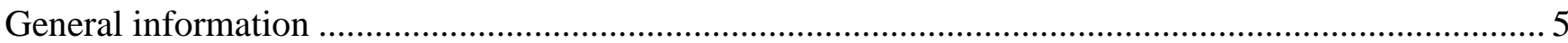

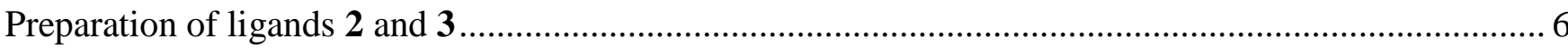

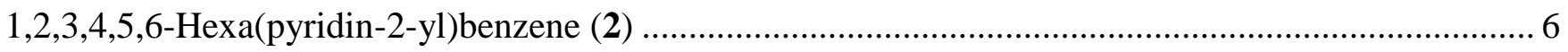

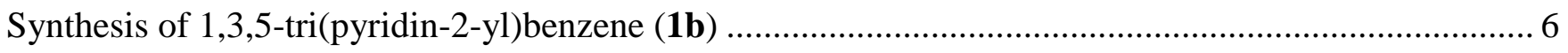

2,2',2"-(2,4,6-Tri(pyridin-2-yl)benzene-1,3,5-triyl)triquinoline (3) ..................................................... 7

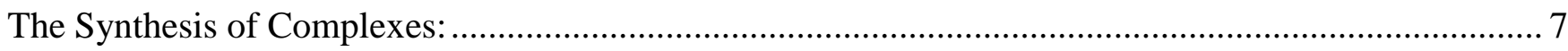

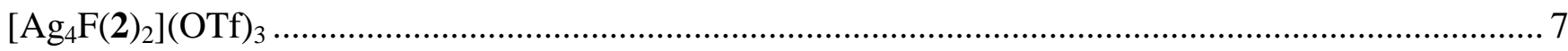

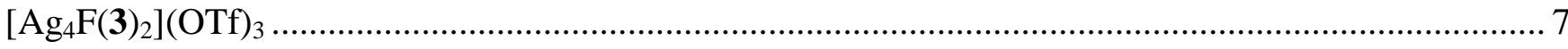

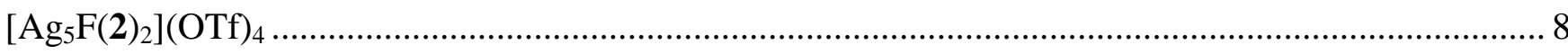

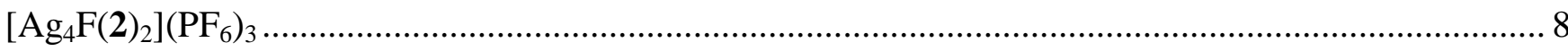

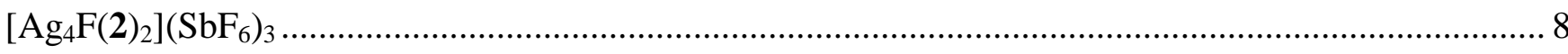

Figure S1: Proportions of $\mathrm{Ag}(\mathrm{I})$ complexes in crude reaction mixtures as a function of different

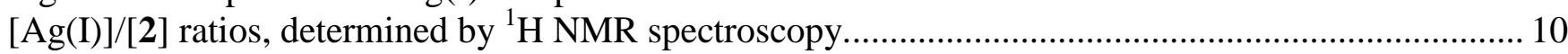

Figure S2: Stacked ${ }^{1} \mathrm{H}$ NMR ( $300 \mathrm{MHz}$, acetone- $\left.d_{6}\right)$ spectra of the complex $\left[\mathrm{Ag}_{4} \mathrm{~F}(\mathbf{2})_{2}\right](\mathrm{OTf})_{3}$ and free

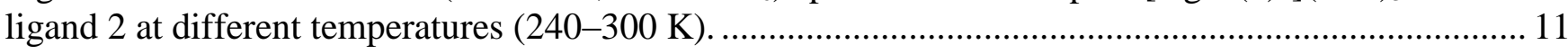

Figure S3: Stacked ${ }^{1} \mathrm{HNMR}\left(300 \mathrm{MHz}, \mathrm{CD}_{3} \mathrm{CN}\right)$ spectra of the complex $\left[\mathrm{Ag}_{4} \mathrm{~F}(\mathbf{2})_{2}\right](\mathrm{OTf})_{3}$ upon heating (300-330 K).

Figure S4: Stacked ${ }^{1} \mathrm{H}$ NMR $\left(300 \mathrm{MHz}\right.$, acetone- $\left.d_{6}\right)$ spectra of the complex $\left[\mathrm{Ag}_{4} \mathrm{~F}(\mathbf{3})_{2}\right](\mathrm{OTf})_{3}$ and free ligand 3 at different temperatures (240-300 K).

Figure S5: Stacked ${ }^{1} \mathrm{H} N M R\left(300 \mathrm{MHz}\right.$, acetone- $\left.d_{6}\right)$ spectra of the complex $\left[\mathrm{Ag}_{5} \mathrm{~F}(\mathbf{2})_{2}\right](\mathrm{OTf})_{4}$ at

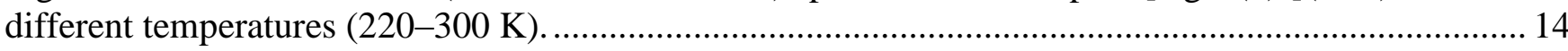

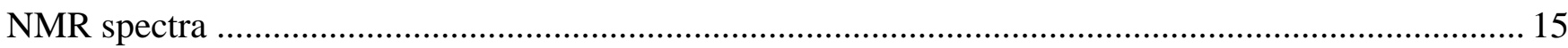

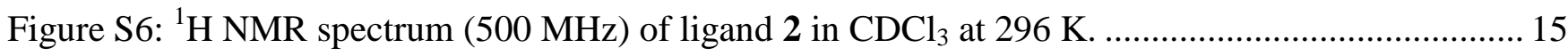

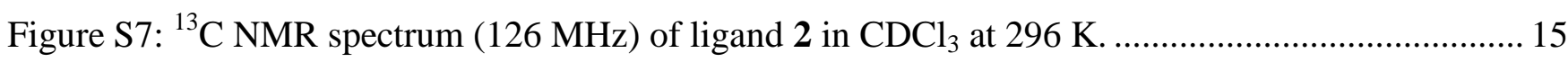

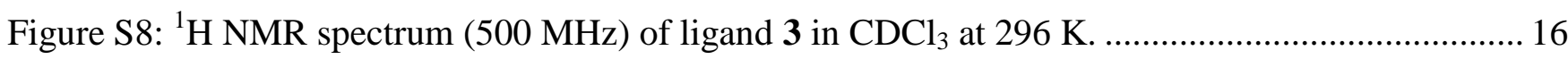

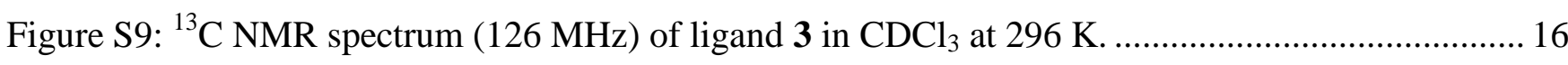

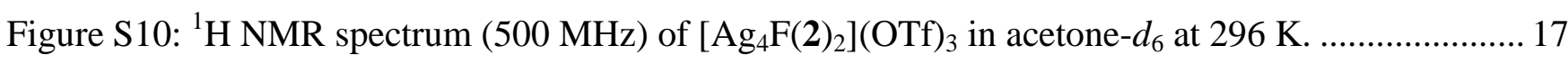

Figure S11: ${ }^{13} \mathrm{C}$ NMR spectrum $(126 \mathrm{MHz})$ of $\left[\mathrm{Ag}_{4} \mathrm{~F}(\mathbf{2})_{2}\right](\mathrm{OTf})_{3}$ in acetone- $d_{6}$ at $296 \mathrm{~K} \ldots \ldots \ldots \ldots \ldots \ldots \ldots . . .17$

Figure S12: ${ }^{19} \mathrm{~F}$ NMR spectrum $(471 \mathrm{MHz})$ of $\left[\mathrm{Ag}_{4} \mathrm{~F}(\mathbf{2})_{2}\right](\mathrm{OTf})_{3}$ in acetone- $d_{6}$ at $296 \mathrm{~K}$ (spectral window from 20 to $-220 \mathrm{ppm}$ ) showing signal for OTf (signal at -63.2 corresponds to $\mathrm{PhCF}_{3}$ ).

Figure S13: ${ }^{19} \mathrm{~F}$ NMR spectrum $(471 \mathrm{MHz})$ of $\left[\mathrm{Ag}_{4} \mathrm{~F}(2)_{2}\right](\mathrm{OTf})_{3}$ in acetone- $d_{6}$ at $296 \mathrm{~K}$ (spectral

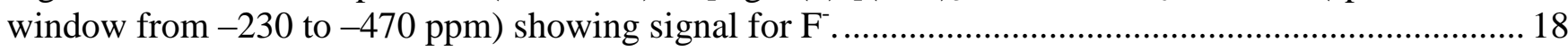

Figure S14: ${ }^{1} \mathrm{H}$ NMR spectrum $(500 \mathrm{MHz})$ of $\left[\mathrm{Ag}_{4} \mathrm{~F}(\mathbf{3})_{2}\right](\mathrm{OTf})_{3}$ in acetone- $d_{6}$ at $296 \mathrm{~K} \ldots \ldots \ldots \ldots \ldots \ldots \ldots . . . . . . . . . . . .19$

Figure S15: ${ }^{13} \mathrm{C}$ NMR spectrum $(126 \mathrm{MHz})$ of $\left[\mathrm{Ag}_{4} \mathrm{~F}(\mathbf{3})_{2}\right](\mathrm{OTf})_{3}$ in acetone- $d_{6}$ at $296 \mathrm{~K}$..................... 19

Figure S16: ${ }^{19} \mathrm{~F}$ NMR spectrum $(471 \mathrm{MHz})$ of $\left[\mathrm{Ag}_{4} \mathrm{~F}(\mathbf{3})_{2}\right](\mathrm{OTf})_{3}$ in acetone- $d_{6}$ at $296 \mathrm{~K}$ (spectral window from 20 to $-220 \mathrm{ppm}$ ) showing signal for OTf (signal at -63.2 corresponds to $\mathrm{PhCF}_{3}$ )..........20

Figure S17: ${ }^{19} \mathrm{~F}$ NMR spectrum $(471 \mathrm{MHz})$ of $\left[\mathrm{Ag}_{4} \mathrm{~F}(\mathbf{3})_{2}\right](\mathrm{OTf})_{3}$ in acetone- $d_{6}$ at $296 \mathrm{~K}$ (spectral

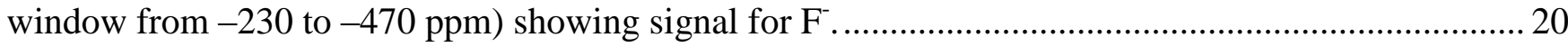

Figure S18: ${ }^{1} \mathrm{H}$ NMR spectrum $(500 \mathrm{MHz})$ of $\left[\mathrm{Ag}_{5} \mathrm{~F}(\mathbf{2})_{2}\right](\mathrm{OTf})_{4}$ in acetone- $d_{6}$ at $296 \mathrm{~K} \ldots \ldots \ldots \ldots \ldots \ldots \ldots . . .21$ 
Figure S19: ${ }^{13} \mathrm{C}$ NMR spectrum $(126 \mathrm{MHz})$ of $\left[\mathrm{Ag}_{5} \mathrm{~F}(\mathbf{2})_{2}\right](\mathrm{OTf})_{4}$ in acetone- $d_{6}$ at $296 \mathrm{~K}$.

Figure S20: ${ }^{19} \mathrm{~F}$ NMR spectrum $(471 \mathrm{MHz})$ of $\left[\mathrm{Ag}_{5} \mathrm{~F}(2)_{2}\right](\mathrm{OTf})_{4}$ in acetone- $d_{6}$ at $296 \mathrm{~K}$ (spectral window from 20 to $-220 \mathrm{ppm}$ ) showing signal for OTf (signal at -63.2 corresponds to $\mathrm{PhCF}_{3}$ ).

Figure S21: ${ }^{19} \mathrm{~F}$ NMR spectrum $(471 \mathrm{MHz})$ of $\left[\mathrm{Ag}_{5} \mathrm{~F}(2)_{2}\right](\mathrm{OTf})_{4}$ in acetone- $d_{6}$ at $296 \mathrm{~K}$ (spectral

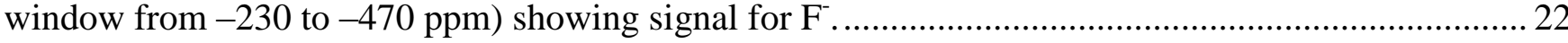

Figure S22: ${ }^{1} \mathrm{H}$ NMR spectrum $(500 \mathrm{MHz})$ of $\left[\mathrm{Ag}_{4} \mathrm{~F}(\mathbf{2})_{2}\right]\left(\mathrm{PF}_{6}\right)_{3}$ in acetone- $d_{6}$ at $296 \mathrm{~K} \ldots \ldots \ldots \ldots \ldots \ldots . . . . . . . . . . .23$

Figure S23: 13C NMR spectrum $(126 \mathrm{MHz})$ of $\left[\mathrm{Ag}_{4} \mathrm{~F}(\mathbf{2})_{2}\right]\left(\mathrm{PF}_{6}\right)_{3}$ in acetone-d6 at $296 \mathrm{~K} \ldots \ldots \ldots \ldots . .23$

Figure S24: ${ }^{19} \mathrm{~F}$ NMR spectrum $(471 \mathrm{MHz})$ of $\left[\mathrm{Ag}_{4} \mathrm{~F}(\mathbf{2})_{2}\right]\left(\mathrm{PF}_{6}\right)_{3}$ in acetone- $d_{6}$ at $296 \mathrm{~K}$ (spectral window from 20 to $-220 \mathrm{ppm}$ ) showing signal for $\mathrm{PF}_{6}^{-}\left(\mathrm{d},{ }^{1} J_{\mathrm{FP}}=708.2 \mathrm{~Hz}\right)$ (signal at -63.2 corresponds to

$\left.\mathrm{PhCF}_{3}\right)$....

Figure S25: ${ }^{19} \mathrm{~F}$ NMR spectrum $(471 \mathrm{MHz})$ of $\left[\mathrm{Ag}_{4} \mathrm{~F}(\mathbf{2})_{2}\right]\left(\mathrm{PF}_{6}\right)_{3}$ in acetone- $d_{6}$ at $296 \mathrm{~K}$ (spectral window from -230 to $-470 \mathrm{ppm}$ ) showing signal for $\mathrm{F}^{-}$ .24

Figure S26: ${ }^{1} \mathrm{H}$ NMR spectrum $(500 \mathrm{MHz})$ of $\left[\mathrm{Ag}_{4} \mathrm{~F}(\mathbf{2})_{2}\right]\left(\mathrm{SbF}_{6}\right)_{3}$ in acetone- $d_{6}$ at $296 \mathrm{~K} \ldots \ldots \ldots \ldots \ldots \ldots . . . . . . . .25$

Figure S27: ${ }^{13} \mathrm{C}$ NMR spectrum $(126 \mathrm{MHz})$ of $\left[\mathrm{Ag}_{4} \mathrm{~F}(2)_{2}\right]\left(\mathrm{SbF}_{6}\right)_{3}$ in acetone- $d_{6}$ at $296 \mathrm{~K} \ldots \ldots \ldots \ldots \ldots \ldots . . . . . . . . .25$

Figure S28: ${ }^{19} \mathrm{~F}$ NMR spectrum $(471 \mathrm{MHz})$ of $\left[\mathrm{Ag}_{4} \mathrm{~F}(2)_{2}\right]\left(\mathrm{SbF}_{6}\right)_{3}$ in acetone- $d_{6}$ at $296 \mathrm{~K}$ (spectral window from 20 to $-220 \mathrm{ppm}$ ) showing signals for $\mathrm{SbF}_{6}^{-}$(superposition of a sextet due to ${ }^{121} \mathrm{SbF}_{6}{ }^{-}$and an octet due to ${ }^{123} \mathrm{SbF}_{6}^{-},{ }^{1} J_{\mathrm{F}}^{121} \mathrm{Sb}=1941,{ }^{1} J_{\mathrm{F}}{ }^{123} \mathrm{Sb}=1051 \mathrm{~Hz}$ ) (signal at -63.2 corresponds to $\mathrm{PhCF}_{3}$ ). .. 26

Figure S29: ${ }^{19} \mathrm{~F}$ NMR spectrum $(471 \mathrm{MHz})$ of $\left[\mathrm{Ag}_{4} \mathrm{~F}(2)_{2}\right]\left(\mathrm{SbF}_{6}\right)_{3}$ in acetone- $d_{6}$ at $296 \mathrm{~K}$ (spectral window from -230 to $-470 \mathrm{ppm}$ ) showing signal for $\mathrm{F}^{-}$ 26

Mass spectra 27

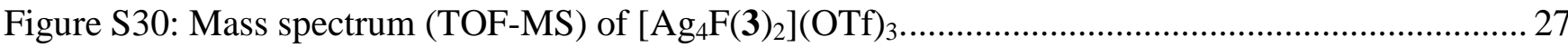

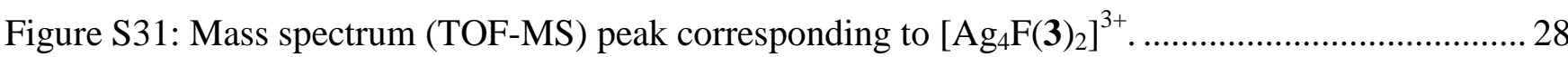

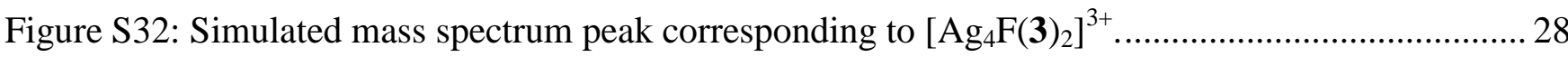

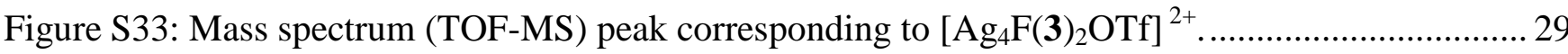

Figure S34: Simulated mass spectrum peak corresponding to $\left[\mathrm{Ag}_{4} \mathrm{~F}(3)_{2} \mathrm{OTf}\right]^{2+}$.............................. 29

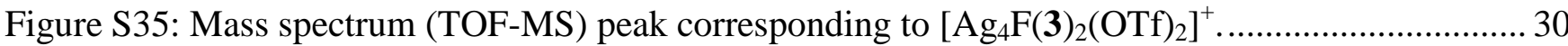

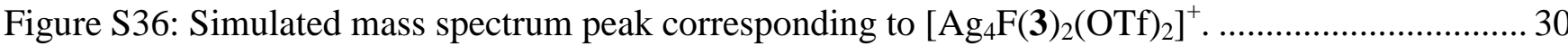

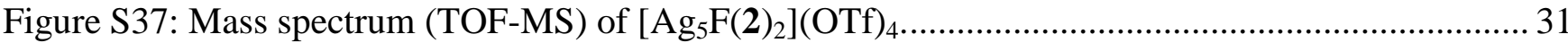

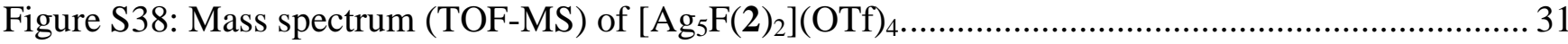

Figure S39: Mass spectrum (TOF-MS) peak corresponding to $\left[\mathrm{Ag}_{4} \mathrm{~F}(\mathbf{2})_{2}\right]^{3+}$ arising from $\left[\operatorname{Ag}_{5} \mathrm{~F}(\mathbf{2})_{2}\right]^{4+}$

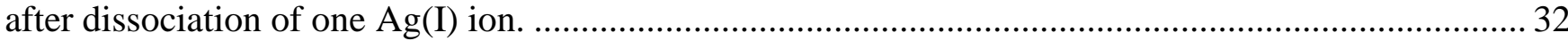

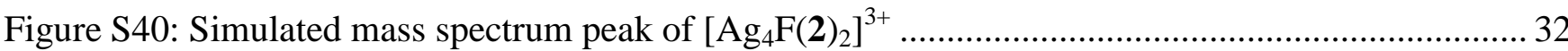

Figure S41: Mass spectrum (TOF-MS) peak corresponding to $\left[\mathrm{Ag}_{4} \mathrm{~F}(2)_{2} \mathrm{OTf}\right]^{2+}$ arising from

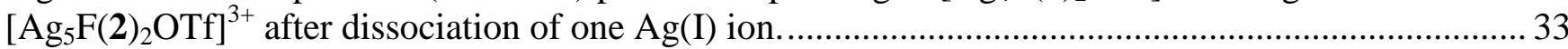

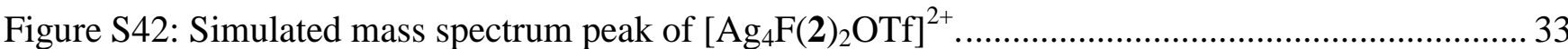

Figure S43: Mass spectrum (TOF-MS) peak corresponding to $\left[\mathrm{Ag}_{4} \mathrm{~F}(\mathbf{2})_{2}(\mathrm{OTf})_{2}\right]^{+}$arising from

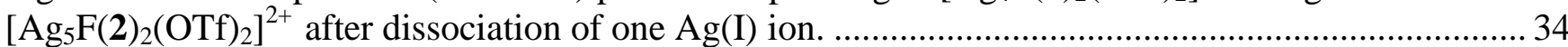

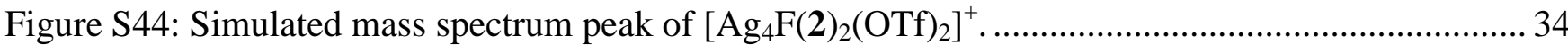

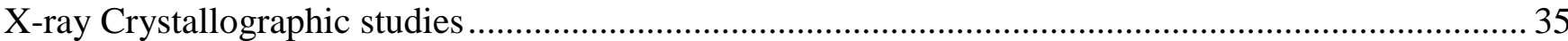

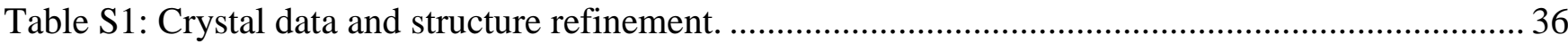




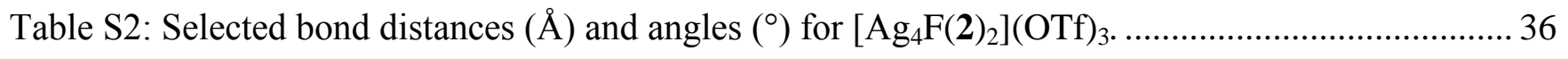

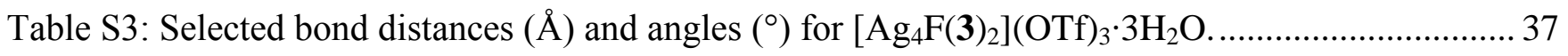

Table S4: Selected bond distances $(\AA)$ and angles $\left(^{\circ}\right)$ for $\left[\mathrm{Ag}_{5} \mathrm{~F}(2)_{2}\right](\mathrm{OTf})_{4} \cdot 2 \mathrm{H}_{2} \mathrm{O} \cdot \mathrm{C}_{3} \mathrm{H}_{6} \mathrm{O} \cdot \mathrm{C}_{6} \mathrm{H}_{6} \ldots \ldots \ldots . . .37$

Figure S45: Schematic presentation of the shielding cones of the pyridine rings. ................................ 38

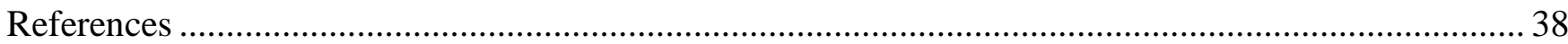




\section{Experimental Procedures}

\section{General information}

All reagents were commercial-grade, and were used without further purification. Reactions were monitored by analytical thin-layer chromatography (TLC) on Fluka silica gel TLC. Merck silica gel 60 PF254 containing gypsum was used to prepare chromatotron plates. Radial chromatography was performed with a Harrison Research chromatotron, model 7924 T. Melting points were determined with SRS OptiMelt MPA100-Automated Melting Point System and are uncorrected. The NMR spectroscopy data were recorded at 296 K with Bruker Avance III $500 \mathrm{MHz}$ for ${ }^{1} \mathrm{H}$ NMR, $126 \mathrm{MHz}$ for ${ }^{13} \mathrm{C}$ NMR and $471 \mathrm{MHz}$ for ${ }^{19} \mathrm{~F}$ NMR. Variable temperature (240-330 K) ${ }^{1} \mathrm{H}$ NMR spectra were measured with Bruker DPX $300 \mathrm{MHz}$. Chemical shifts (in ppm) for ${ }^{1} \mathrm{H}$ NMR are referenced against TMS as an internal standard, or residual resonance of the protiated part of the deuterated solvent (2.05 ppm for acetone- $d_{6}$, and $1.94 \mathrm{ppm}$ for $\mathrm{CD}_{3} \mathrm{CN}$ ). The ${ }^{13} \mathrm{C}$ NMR data are referenced against the central line of $\mathrm{CDCl}_{3}\left(\mathrm{t}, \delta=77.16 \mathrm{ppm}\right.$ ) or acetone- $d_{6}$ (sept, $29.84 \mathrm{ppm}$ ). The coupling constants are given in Hertz $(\mathrm{Hz})$. For the multiplicity signification, the standard abbreviation was used: s (singlet), $d$ (doublet), $t$ (triplet), q (quartet), sept (septet), and m (multiplet). IR spectra were obtained with a Bruker ALPHA FT-IR spectrophotometer and reported in reciprocal centimetres $\left(\mathrm{cm}^{-1}\right)$. High-resolution mass spectra were recorded with Agilent 6224 Accurate Mass TOF LC/MS and Thermo Fisher Q-Exactive instruments, while mass spectra were recorded with a Micromass Waters Q-Tof Premier instrument. Elemental analyses $(\mathrm{C}, \mathrm{H}, \mathrm{N})$ were performed with a PerkinElmer 2400 Series II CHNS/O Analyzer. The reactions with microwave heating were performed with a CEM Discovery Microwave. The machine consists of a continuous, focused-microwave, power-delivery system with an operator-selectable power output from 0 to $300 \mathrm{~W}$. Reactions were performed in glass vessels (capacity $10 \mathrm{~mL}$ ) sealed with a septum. The pressure was controlled by a load cell connected to the vessel via the septum. The temperature of the content of the vessel was monitored using a calibrated, infrared, temperature controller mounted under the reaction vessel. All the mixtures were stirred with a Teflon-coated, magnetic stirring bar in the vessel. A ramp temperature of $5 \mathrm{~min}$ was set for each experiment. 


\section{Preparation of ligands 2 and 3}

\section{1,2,3,4,5,6-Hexa(pyridin-2-yl)benzene (2)}<smiles>c1ccc(-c2c(-c3ccccn3)c(-c3ccccn3)c(-c3ccccn3)c(-c3ccccn3)c2-c2ccccn2)nc1</smiles>

2

A microwave vial was loaded with 2-phenylpyridine (1a) $(146 \mu \mathrm{L}, 1 \mathrm{mmol})$ and 2bromopyridine ( $760 \mu \mathrm{L}, 8 \mathrm{mmol}),\left[\mathrm{RuCl}_{2}(p \text {-cymene })\right]_{2}(60 \mathrm{mg}, 0.1 \mathrm{mmol}), \mathrm{PPh}_{3}(52 \mathrm{mg}$, $0.2 \mathrm{mmol}$ ), KOPiv (56 mg, 0,40 mmol), and $\mathrm{Na}_{2} \mathrm{CO}_{3}(1,040 \mathrm{mg}, 10 \mathrm{mmol})$. The mixture was suspended in $2 \mathrm{~mL}$ of $\mathrm{H}_{2} \mathrm{O}$, bubbled with $\mathrm{Ar}$ for $3 \mathrm{~min}$. The mixture was heated at $200{ }^{\circ} \mathrm{C}$ under microwave irradiation $(\max 100 \mathrm{~W}$ ) for $4 \mathrm{~h}$. The reaction mixture was then cooled to room temperature and diluted with $20 \mathrm{~mL} \mathrm{DCM}$ and $20 \mathrm{~mL} \mathrm{H}_{2} \mathrm{O}$. The product was extracted with DCM $(2 \times 20 \mathrm{~mL})$. The combined organic phases were dried over anh. $\mathrm{Na}_{2} \mathrm{SO}_{4}$, filtrated and evaporated in vacuo. Crude product after extraction was triturated with EtOAc (20 $\mathrm{mL})$, to obtain pure ligand $2(519 \mathrm{mg}, 97 \%)$ as a pale yellow solid. Analytical and spectroscopic data are in agreement with literature data [1].

\section{Synthesis of 1,3,5-tri(pyridin-2-yl)benzene (1b)}<smiles>Brc1cc(Br)cc(Br)c1</smiles>

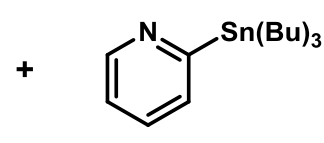

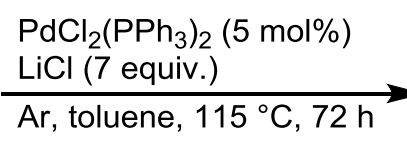<smiles>c1ccc(-c2cc(-c3ccccn3)cc(-c3ccccn3)c2)nc1</smiles>

1b

Compound 2 was prepared by following slightly modified literature procedure for Stille reaction [2]. A mixture of 2-tri-n-butylstannylpyridine $(1.17 \mathrm{~mL}, 3.5 \mathrm{mmol}), \quad$ 1,3,5-tribromobenzene $(317 \mathrm{mg}, 1 \mathrm{mmol})$, bis(triphenylphosphine)palladium(II) chloride (34 mg, $0.05 \mathrm{mmol}$ ) and lithium chloride (294 mg, $7 \mathrm{mmol}$ ) were suspended in dry toluene $(3 \mathrm{~mL})$ and degassed by five freeze-pump-thaw cycles. The reaction mixture was than stirred and heated under reflux at $115^{\circ} \mathrm{C}$ for $72 \mathrm{~h}$ under $\mathrm{Ar}$ atmosphere. The solution was filtrated and residue was washed with toluene $(3 \mathrm{~mL})$. Saturated aqueous potassium fluoride solution $(5 \mathrm{ml})$ was added and the resulting two-phase system was stirred for $30 \mathrm{~min}$. The solid tin residue was removed by filtration and washed with toluene $(3 \times 3 \mathrm{~mL})$. Phases were separated and the organic phase was dried over anh. $\mathrm{Na}_{2} \mathrm{SO}_{4}$, filtered and evaporated in vacuo. The crude product was triturated with petroleum ether and the precipitate was filtered off, washed with with $\mathrm{Et}_{2} \mathrm{O}(2 \times 5 \mathrm{~mL})$ and dried to obtain compound $1 \mathbf{b}(154 \mathrm{mg}, 50 \%)$ as an orange solid. Analytical and spectroscopic data are in agreement with literature data [2]. 


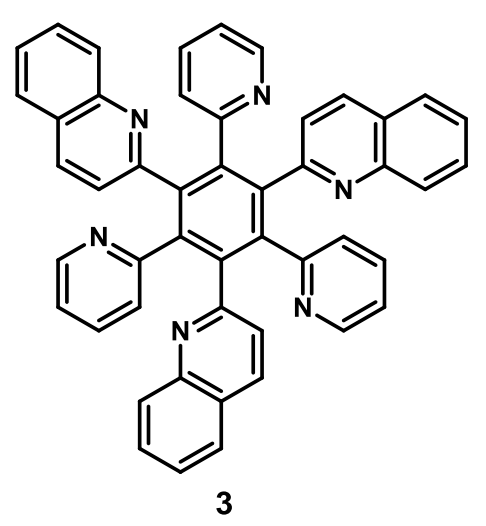

A microwave vial was loaded with 1,3,5-tri(pyridin-2-yl)benzene (1b) (77 mg, $0.25 \mathrm{mmol}), 2$-bromoquinoline (260 $\mathrm{mg}, 1.25 \mathrm{mmol}),\left[\mathrm{RuCl}_{2}(p \text {-cymene })\right]_{2}(15$ $\mathrm{mg}, 0.025 \mathrm{mmol}), \mathrm{PPh}_{3}(13 \mathrm{mg}, 0.05 \mathrm{mmol}), \mathrm{KOPiv}(14 \mathrm{mg}, 0,10 \mathrm{mmol})$, and $\mathrm{Na}_{2} \mathrm{CO}_{3}(130 \mathrm{mg}, 1,25 \mathrm{mmol})$. The mixture was suspended in $1 \mathrm{~mL}$ of $\mathrm{H}_{2} \mathrm{O}$, bubbled with $\mathrm{Ar}$ for $3 \mathrm{~min}$ and heated at $200{ }^{\circ} \mathrm{C}$ under microwave irradiation $(\max 100 \mathrm{~W})$ for $4 \mathrm{~h}$. The reaction mixture was then cooled to room temperature and diluted with $10 \mathrm{~mL}$ DCM and $10 \mathrm{~mL} \mathrm{H}_{2} \mathrm{O}$. The product was extracted with DCM $(2 \times 10 \mathrm{~mL})$. The combined organic phases were dried over anh. $\mathrm{Na}_{2} \mathrm{SO}_{4}$, filtered and evaporated in vacuo. The crude product was further purified by radial chromatography on silica gel using mixture of DCM and MeOH. (DCM/MeOH: 50/1 to 5/1) to obtain ligand 3 (150 mg, 87\%) as a pale green solid. Analytical and spectroscopic data are in agreement with literature data [1].

\section{The Synthesis of Complexes}

$\left[\mathrm{Ag}_{4} \mathbf{F}(2)_{2}\right](\mathbf{O T f})_{3}$

A crew cap scintillation vial was loaded with ligand 2 (28 mg, $0.05 \mathrm{mmol})$, AgOTf (19.5 mg. $0.075 \mathrm{mmol})$ and $\mathrm{AgF}$ (3.4 mg, $0.025 \mathrm{mmol}$ ). The mixture was dissolved in $1 \mathrm{~mL}$ of $\mathrm{MeOH}$ and stirred in the dark at room temperature for $12 \mathrm{~h}$. After that time $\mathrm{Et}_{2} \mathrm{O}(2 \mathrm{~mL})$ was added to precipitate the product, which was filtered off, washed with $\mathrm{H}_{2} \mathrm{O}(1 \mathrm{~mL})$ and $\mathrm{Et}_{2} \mathrm{O}(2 \times 1 \mathrm{~mL})$ and dried to obtain the pure complex $\left[\mathrm{Ag}_{4} \mathrm{~F}(2)_{2}\right](\mathrm{OTf})_{3}(38 \mathrm{mg}$, $0.0195 \mathrm{mmol}, 78 \%$ yield) as a white solid. Mp. $>300{ }^{\circ} \mathrm{C}$ (dec.). ${ }^{1} \mathbf{H}$ NMR (500 MHz, acetone- $\left.d_{6}\right): \delta=8.10(\mathrm{~d}, J=$ $5.0 \mathrm{~Hz}, 1 \mathrm{H}), 7.91(\mathrm{~d}, J=7.9 \mathrm{~Hz}, 1 \mathrm{H}), 7.74(\mathrm{td}, J=7.7,1.7 \mathrm{~Hz}, 1 \mathrm{H}), 7.17$ (ddd, $J=7.6,5.1,1.3 \mathrm{~Hz}, 1 \mathrm{H}) .{ }^{13} \mathbf{C}$ NMR (126 MHz, acetone- $\left.d_{6}\right): \delta=157.8,150.3,141.4,138.7,128.5,124.1121 .6$ (q, $\left.J=322.0 \mathrm{~Hz}\right) .{ }^{19} \mathbf{F}$ NMR (471 MHz, acetone- $d_{6}$ ): $\delta-78.6$ (OTf), -315.9 (F-). IR (ATR): 1592, 1566, 1483, 1405, 1256, 1221, 1151, 1027 , 997, 806, 754, $635 \mathrm{~cm}^{-1}$. HR-MS (ESI) m/z calcd for $\mathrm{C}_{72} \mathrm{H}_{48} \mathrm{~N}_{12} \mathrm{FAg}_{4}$ [M-3OTf] ${ }^{3+}$ : 509.0099, found: 509.0100. Elemental analysis calcd (\%) for $\mathrm{C}_{75} \mathrm{H}_{48} \mathrm{Ag}_{4} \mathrm{~F}_{10} \mathrm{~N}_{12} \mathrm{O}_{9} \mathrm{~S}_{3} \times 3 \mathrm{H}_{2} \mathrm{O}$ : C 44.31, H 2.68, N 8.27; found: $\mathrm{C} 44.25, \mathrm{H} 2.45$, N 8.19.

\section{$\left[\mathrm{Ag}_{4} \mathbf{F}(3)_{2}\right](\mathrm{OTf})_{3}$}

A crew cap scintillation vial was loaded with ligand 3 (34,5 mg, $0.05 \mathrm{mmol})$, AgOTf (19.5 mg. $0.075 \mathrm{mmol})$ and $\mathrm{AgF}(3.4 \mathrm{mg}, 0.025 \mathrm{mmol})$. The mixture was dissolved in $1 \mathrm{~mL}$ of $\mathrm{MeOH}$ and stirred in the dark at room temperature for $12 \mathrm{~h}$. After that time $\mathrm{Et}_{2} \mathrm{O}(2 \mathrm{~mL})$ was added to precipitate the product, which was filtered off, washed with $\mathrm{H}_{2} \mathrm{O}(1 \mathrm{~mL})$ and $\mathrm{Et}_{2} \mathrm{O}(2 \times 1 \mathrm{~mL})$ and dried to obtain the pure complex $\left[\mathrm{Ag}_{4} \mathrm{~F}(3)_{2}\right](\mathrm{OTf})_{3}(40 \mathrm{mg}$, $0.018 \mathrm{mmol}, 71 \%$ yield) as a white solid. Mp. $>300{ }^{\circ} \mathrm{C}$ (dec.). ${ }^{1} \mathbf{H}$ NMR $\left(500 \mathrm{MHz}\right.$, acetone- $\left.d_{6}\right): \delta=8.38(\mathrm{~d}, J=$ $8.5 \mathrm{~Hz}, 1 \mathrm{H}), 8.27(\mathrm{~d}, J=8.5 \mathrm{~Hz}, 1 \mathrm{H}), 8.16(\mathrm{dt}, J=7.9,1.1 \mathrm{~Hz}, 1 \mathrm{H}), 8.03(\mathrm{~d}, J=5.0 \mathrm{~Hz}, 1 \mathrm{H}), 7.84(\mathrm{~d}, J=7.9 \mathrm{~Hz}$, $1 \mathrm{H}), 7.26$ (ddd, $J=8.0,6.9,1.2 \mathrm{~Hz}, 1 \mathrm{H}), 7.01$ (ddd, $J=7.6,5.1,1.3 \mathrm{~Hz}, 1 \mathrm{H}), 6.71(\mathrm{~d}, J=8.7 \mathrm{~Hz}, 1 \mathrm{H}), 6.52$ (ddd, $J=8.5,6.9,1.3 \mathrm{~Hz}, 1 \mathrm{H}) .{ }^{13} \mathbf{C}$ NMR $\left(126 \mathrm{MHz}\right.$, acetone- $\left.d_{6}\right): \delta=159.9,158.1,150.5,146.2,142.3,141.5,139.1$, 139.0, 130.5, 129.0, 128.9, 128.5, 128.3, 127.8, 125.5, 124.3121 .6 (q, $J=322.0 \mathrm{~Hz}) .{ }^{19} \mathbf{F}$ NMR (471 MHz, 
acetone- $\left.d_{6}\right): \delta-78.6(\mathrm{OTf}),-312.3\left(\mathrm{~F}^{-}\right) . \quad$ IR (ATR): $1604,1569,1327,1259,1165,1122,1078,1029,1020,868$, $729,637 \mathrm{~cm}^{-1}$. ESI-MS $\mathrm{m} / \mathrm{z}$ for $\mathrm{C}_{96} \mathrm{H}_{60} \mathrm{Ag}_{4} \mathrm{FN}_{12}[\mathrm{M}-3 \mathrm{OTf}]^{3+}$ : 610.4. Elemental analysis calcd $(\%)$ for $\mathrm{C}_{99} \mathrm{H}_{60} \mathrm{Ag}_{4} \mathrm{~F}_{10} \mathrm{~N}_{12} \mathrm{O}_{9} \mathrm{~S}_{3}:$ C 52.17, H 2.65, N 7.37; found: C 46.00, H 2.35, N 6.16.

\section{$\left[\mathrm{Ag}_{5} \mathrm{~F}(2)_{2}\right](\mathrm{OTf})_{4}$}

A screw cap scintillation vial was loaded with ligand $2(28 \mathrm{mg}, 0.05 \mathrm{mmol})$, AgOTf $(32,5 \mathrm{mg} .0 .125 \mathrm{mmol})$ and $\mathrm{AgF}$ (3.4 mg, $0.025 \mathrm{mmol}$ ). The mixture was dissolved in $1 \mathrm{~mL}$ of $\mathrm{MeOH}$ and stirred in the dark at room temperature for $12 \mathrm{~h}$. After that time $\mathrm{Et}_{2} \mathrm{O}(2 \mathrm{~mL})$ was added to precipitate the product, which was filtered off, washed with $\mathrm{H}_{2} \mathrm{O}(1 \mathrm{~mL})$ and $\mathrm{Et}_{2} \mathrm{O}(2 \times 1 \mathrm{~mL})$ and dried to obtain the pure complex $\left[\mathrm{Ag}_{5} \mathrm{~F}(\mathbf{2})_{2}\right](\mathrm{OTf})_{4}(40 \mathrm{mg}$, $0.0215 \mathrm{mmol}, 86 \%$ yield) as a white solid. Mp. $>300{ }^{\circ} \mathrm{C}$ (dec.). ${ }^{1} \mathbf{H}$ NMR $\left(500 \mathrm{MHz}\right.$, acetone- $\left.d_{6}\right): \delta=8.38(\mathrm{~d}, J=$ $5.1 \mathrm{~Hz}, 1 \mathrm{H}), 8.15(\mathrm{dt}, J=7.9,1.2 \mathrm{~Hz}, 1 \mathrm{H}), 7.89(\mathrm{td}, J=7.8,1.6 \mathrm{~Hz}, 1 \mathrm{H}), 7.32(\mathrm{ddd}, J=7.7,5.2,1.3 \mathrm{~Hz}, 1 \mathrm{H}) .{ }^{13} \mathbf{C}$ NMR (126 MHz, acetone- $\left.d_{6}\right): \delta=157.3,152.1,141.9,140.2,129.7,125.2121 .3$ (q, $\left.J=321.2 \mathrm{~Hz}\right) .{ }^{\mathbf{1}} \mathbf{F}$ NMR (471 MHz, acetone- $d_{6}$ ): $\delta-78.7$ (OTf), -284.5 (F-). IR (ATR): 1592, 1565, 1434, 1405, 1258, 1221, 1150, 1028, 997, 806, 754, $635 \mathrm{~cm}^{-1}$. ESI-MS m/z for $\mathrm{C}_{72} \mathrm{H}_{48} \mathrm{Ag}_{4} \mathrm{FN}_{12}\left[\mathrm{M}-\mathrm{Ag}^{+}-3 \mathrm{OTf}\right]^{3+}:$ 510.3. Elemental analysis calcd (\%) for $\mathrm{C}_{76} \mathrm{H}_{48} \mathrm{Ag}_{5} \mathrm{~F}_{13} \mathrm{~N}_{12} \mathrm{O}_{12} \mathrm{~S}_{4} \times \mathrm{C}_{6} \mathrm{H}_{6}$ : C 42.56, H 2.35, N 7.26; found: C 42.85, H 2.40, N 7.86.

\section{$\left[\mathrm{Ag}_{4} \mathbf{F}(2)_{2}\right]\left(\mathrm{PF}_{6}\right)_{3}$}

A screw cap scintillation vial was loaded with ligand $2(28 \mathrm{mg}, 0.05 \mathrm{mmol}), \mathrm{AgPF}_{6}(19 \mathrm{mg} .0 .075 \mathrm{mmol})$ and $\mathrm{AgF}(3.4 \mathrm{mg}, 0.025 \mathrm{mmol})$. The mixture was dissolved in $1 \mathrm{~mL}$ of $\mathrm{MeOH}$ and stirred in the dark at room temperature for $12 \mathrm{~h}$. After that time $\mathrm{Et}_{2} \mathrm{O}(2 \mathrm{~mL})$ was added to precipitate the product, which was filtered off, washed with $\mathrm{H}_{2} \mathrm{O}(1 \mathrm{~mL})$ and $\mathrm{Et}_{2} \mathrm{O}(2 \times 1 \mathrm{~mL})$ and dried to obtain the pure complex $\left[\mathrm{Ag}_{4} \mathrm{~F}(2)_{2}\right]\left(\mathrm{PF}_{6}\right)_{3}(48 \mathrm{mg}$, $0.0205 \mathrm{mmol}, 82 \%$ yield) as a white solid. Mp. $>300{ }^{\circ} \mathrm{C}$ (dec.). ${ }^{1} \mathbf{H}$ NMR $\left(500 \mathrm{MHz}\right.$, acetone- $\left.d_{6}\right): \delta=8.14(\mathrm{~d}, J=$ $5.1 \mathrm{~Hz}, 1 \mathrm{H}), 7.78(\mathrm{td}, J=7.6,1.6 \mathrm{~Hz}, 1 \mathrm{H}), 7.74(\mathrm{dt}, J=7.7,1.3 \mathrm{~Hz}, 1 \mathrm{H}), 7.21(\mathrm{ddd}, J=7.4,5.0,1.5 \mathrm{~Hz}, 1 \mathrm{H}) .{ }^{13} \mathbf{C}$ NMR $\left(126 \mathrm{MHz}\right.$, acetone- $\left.d_{6}\right): \delta=156.5,149.8,140.8,138.1,127.3,123.4 .{ }^{19} \mathbf{F}$ NMR $\left(471 \mathrm{MHz}\right.$, acetone- $\left.d_{6}\right): \delta-$ $72.5\left(\mathrm{~d},{ }^{1} J_{\mathrm{FP}}=708.2 \mathrm{~Hz}, \mathrm{PF}_{6}^{-}\right),-316.0\left(\mathrm{~F}^{-}\right)$. IR $(\mathrm{ATR}): 1593,1486,1404,875,836,807,754 \mathrm{~cm}^{-1}$. Elemental analysis calcd (\%) for $\mathrm{C}_{72} \mathrm{H}_{48} \mathrm{Ag}_{4} \mathrm{~F}_{19} \mathrm{~N}_{12} \mathrm{P}_{3} \times 2 \mathrm{H}_{2} \mathrm{O}$ : C 43.18, $\mathrm{H}$ 2.63, $\mathrm{N}$ 8.39; found: $\mathrm{C} 42.89, \mathrm{H} 2.30, \mathrm{~N}$ 8.29.

\section{$\left[\mathrm{Ag}_{4} \mathbf{F}(2)_{2}\right]\left(\mathrm{SbF}_{6}\right)_{3}$}

A screw cap scintillation vial was loaded with ligand 2 (28 mg, $0.05 \mathrm{mmol}), \mathrm{AgSbF}_{6}(26 \mathrm{mg} .0 .075 \mathrm{mmol})$ and $\mathrm{AgF}(3.4 \mathrm{mg}, 0.025 \mathrm{mmol})$. The mixture was dissolved in $1 \mathrm{~mL}$ of $\mathrm{MeOH}$ and stirred in the dark at room temperature for $12 \mathrm{~h}$. After that time $\mathrm{Et}_{2} \mathrm{O}(2 \mathrm{~mL})$ was added to precipitate the product, which was filtered off, washed with $\mathrm{H}_{2} \mathrm{O}(1 \mathrm{~mL})$ and $\mathrm{Et}_{2} \mathrm{O}(2 \times 1 \mathrm{~mL})$ and dried to obtain the pure complex $\left[\mathrm{Ag}_{4} \mathrm{~F}(2)_{2}\right]\left(\mathrm{SbF}_{6}\right)_{3}(45 \mathrm{mg}$, $0.02 \mathrm{mmol}, 80 \%$ yield) as a white solid. Mp. $>300{ }^{\circ} \mathrm{C}\left(\mathrm{dec}\right.$.). ${ }^{1} \mathbf{H}$ NMR $\left(500 \mathrm{MHz}\right.$, acetone- $\left.d_{6}\right): \delta=8.14(\mathrm{~d}, J=$ $5.0 \mathrm{~Hz}, 1 \mathrm{H}), 7.86-7.70(\mathrm{~m}, 2 \mathrm{H}), 7.21(\mathrm{ddd}, J=7.4,5.1,1.5 \mathrm{~Hz}, 1 \mathrm{H}) .{ }^{19} \mathbf{F}$ NMR $\left(471 \mathrm{MHz}\right.$, acetone- $\left.d_{6}\right): \delta-123.2$ (superposition of a sextet due to ${ }^{121} \mathrm{SbF}_{6}^{-}$and an octet due to ${ }^{123} \mathrm{SbF}_{6}^{-},{ }^{1} J_{\mathrm{F}}{ }^{121} \mathrm{Sb}=1941,{ }^{1} J_{\mathrm{F}}{ }^{123} \mathrm{Sb}=1051 \mathrm{~Hz}$ ), -316.4 $\left(\mathrm{F}^{-}\right) .{ }^{13} \mathrm{C}$ NMR (126 MHz, acetone- $\left.d_{6}\right): \delta=157.3,150.7,141.8,139.0,128.2,124.3$. IR (ATR): 1592, 1565, 1484, $1405,997,807,753,654 \mathrm{~cm}^{-1}$. Elemental analysis calcd (\%) for $\mathrm{C}_{72} \mathrm{H}_{48} \mathrm{Ag}_{4} \mathrm{~F}_{19} \mathrm{~N}_{12} \mathrm{Sb}_{3}$ : C 38.61, H 2.16, N 7.51; found: C 38.50, H 2.08, N 7.44. 
Synthesis of Complex $\left[\mathrm{Ag}_{5} \mathrm{~F}(2)_{2}\right](\mathrm{OTf})_{4}$ from $\left[\mathrm{Ag}_{4} \mathrm{~F}(2)_{2}\right](\mathrm{OTf})_{3}$. A screw cap scintillation vial was loaded with complex $\left[\mathrm{Ag}_{4} \mathrm{~F}(\mathbf{2})_{2}\right](\mathrm{OTf})_{3}(10 \mathrm{mg}, 0.005 \mathrm{mmol})$ and $\mathrm{AgOTf}(3.8 \mathrm{mg} .0 .0125 \mathrm{mmol})$. The mixture was dissolved in $0.5 \mathrm{~mL}$ of $\mathrm{MeOH}$ and stirred in the dark at room temperature for $12 \mathrm{~h}$. After that time $\mathrm{Et}_{2} \mathrm{O}(1 \mathrm{~mL})$ was added to precipitate the product, which was filtered off, washed with $\mathrm{H}_{2} \mathrm{O}(0.5 \mathrm{~mL})$ and $\mathrm{Et}_{2} \mathrm{O}(2 \times 0.5 \mathrm{~mL})$ and dried to obtain the complex $\left[\mathrm{Ag}_{5} \mathrm{~F}(2)_{2}\right](\mathrm{OTf})_{4}(6.8 \mathrm{mg}, 0.003 \mathrm{mmol}, 61 \%)$ as a white solid.

Synthesis of Complex $\left[\mathrm{Ag}_{4} \mathrm{~F}(2)_{2}\right](\mathrm{OTf})_{3}$ from $\left[\mathrm{Ag}_{5} \mathrm{~F}(2)_{2}\right](\mathrm{OTf})_{4}$. A screw cap scintillation vial was loaded with complex $\left[\mathrm{Ag}_{5} \mathrm{~F}(\mathbf{2})_{2}\right](\mathrm{OTf})_{4}(12 \mathrm{mg}, 0.005 \mathrm{mmol})$, which was suspended in $1 \mathrm{~mL}$ of $\mathrm{H}_{2} \mathrm{O}$ and stirred in the dark at room temperature for $0.5 \mathrm{~h}$. After that time the product was filtered off, and washed with $\mathrm{H}_{2} \mathrm{O}(0.5 \mathrm{~mL})$ and $\mathrm{Et}_{2} \mathrm{O}$ $(2 \times 0.5 \mathrm{~mL})$ and dried to obtain the pure complex $\left[\mathrm{Ag}_{4} \mathrm{~F}(2)_{2}\right](\mathrm{OTf})_{3}(7 \mathrm{mg}, 0.0036 \mathrm{mmol}, 72 \%)$ as a white solid.

Synthesis of Complex $\left[\mathrm{Ag}_{4} \mathrm{~F}(2)_{2}\right](\mathrm{OTf})_{3}$ from $\left[\mathrm{Ag}_{5} \mathrm{~F}(2)_{2}\right](\mathrm{OTf})_{4}$. A screw cap scintillation vial was loaded with complex $\left[\mathrm{Ag}_{5} \mathrm{~F}(\mathbf{2})_{2}\right](\mathrm{OTf})_{4}(11 \mathrm{mg}, 0.005 \mathrm{mmol})$, ligand $2(1.4 \mathrm{mg}, 0.0025 \mathrm{mmol})$ and $\mathrm{KF}(14.5 \mathrm{mg}, 0.25 \mathrm{mmol})$. The mixture was suspended in $0.5 \mathrm{~mL}$ of $\mathrm{MeOH}$ and stirred in the dark at room temperature for $12 \mathrm{~h}$. After that time $\mathrm{Et}_{2} \mathrm{O}(1 \mathrm{~mL})$ was added to precipitate the product, which was filtered off, washed with $\mathrm{H}_{2} \mathrm{O}(0.5 \mathrm{~mL})$ and $\mathrm{Et}_{2} \mathrm{O}(2 \times 0.5 \mathrm{~mL})$ and dried to obtain the complex $\left[\mathrm{Ag}_{4} \mathrm{~F}(2)_{2}\right](\mathrm{OTf})_{3}(10 \mathrm{mg}, 0.005 \mathrm{mmol}, 80 \%)$ as a white solid.

Dissociation of Complex $\left[\mathrm{Ag}_{4} \mathbf{F}(2)_{2}\right](\mathrm{OTf})_{3}$ with $\mathrm{NaCl}$. A screw cap scintillation vial was loaded with complex $\left[\mathrm{Ag}_{4} \mathrm{~F}(2)_{2}\right](\mathrm{OTf})_{3}(20 \mathrm{mg}, 0.01 \mathrm{mmol})$ and $\mathrm{NaCl}(5,8 \mathrm{mg}, 0.1 \mathrm{mmol})$. The mixture was suspended in $1 \mathrm{~mL}$ of $\mathrm{MeOH}$ and stirred in the dark at room temperature for $12 \mathrm{~h}$. After that time $\mathrm{MeOH}$ was evaporated in vacuo. The crude product was suspended in DCM (2 mL), filtered and filtrate was evaporated to obtain the pure ligand 2 ( 8 $\mathrm{mg}, 0.015 \mathrm{mmol}, 80 \%$ ) as a white solid. 
Proportions of complexes $\left[\mathrm{Ag}_{4} \mathrm{~F}(2)_{2}\right](\mathrm{OTf})_{3}$ and $\left[\mathrm{Ag}_{5} \mathrm{~F}(2)_{2}\right](\mathrm{OTf})_{4}$ in crude reaction mixture as a function of different $[\mathrm{Ag}(\mathrm{I})] /[2]$ ratios

Screw cap scintillation vial was loaded with ligand 2 ( $28 \mathrm{mg}, 0.05 \mathrm{mmol})$, AgF (3.4 mg, $0.025 \mathrm{mmol}$ ) and AgOTf $(0.075-0.125 \mathrm{mmol})$. The mixture was dissolved in $1 \mathrm{~mL} \mathrm{MeOH}$ and stirred in the dark at room temperature for $12 \mathrm{~h}$. After that, $\mathrm{MeOH}$ was evaporated in vacuo and the crude reaction mixture was analysed by ${ }^{1} \mathrm{H}$ NMR spectroscopy in acetone- $d_{6}$.

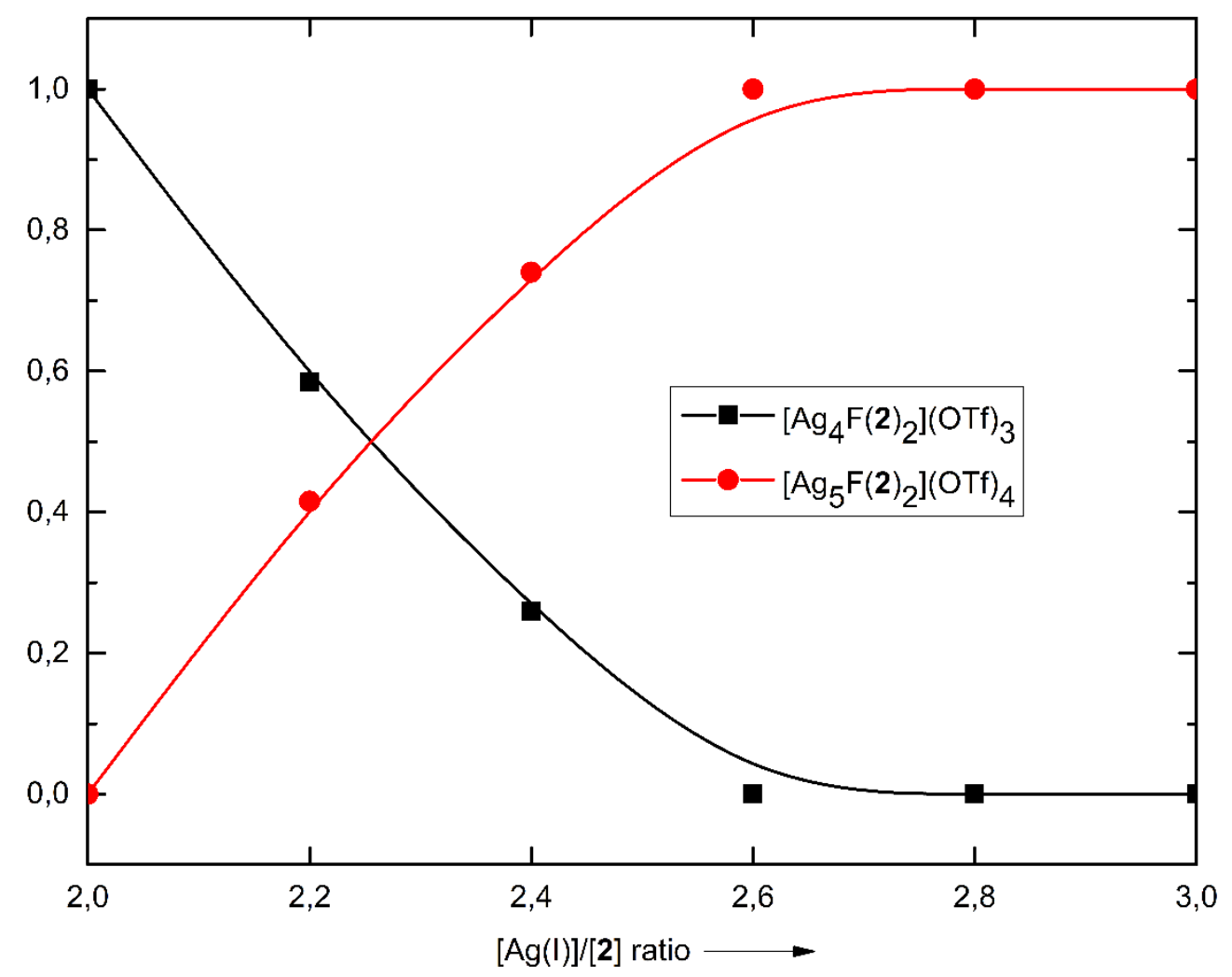

Figure S1: Proportions of $\operatorname{Ag}(\mathrm{I})$ complexes in crude reaction mixtures as a function of different $[\mathrm{Ag}(\mathrm{I})] /[2]$ ratios, determined by ${ }^{1} \mathrm{H}$ NMR spectroscopy. 


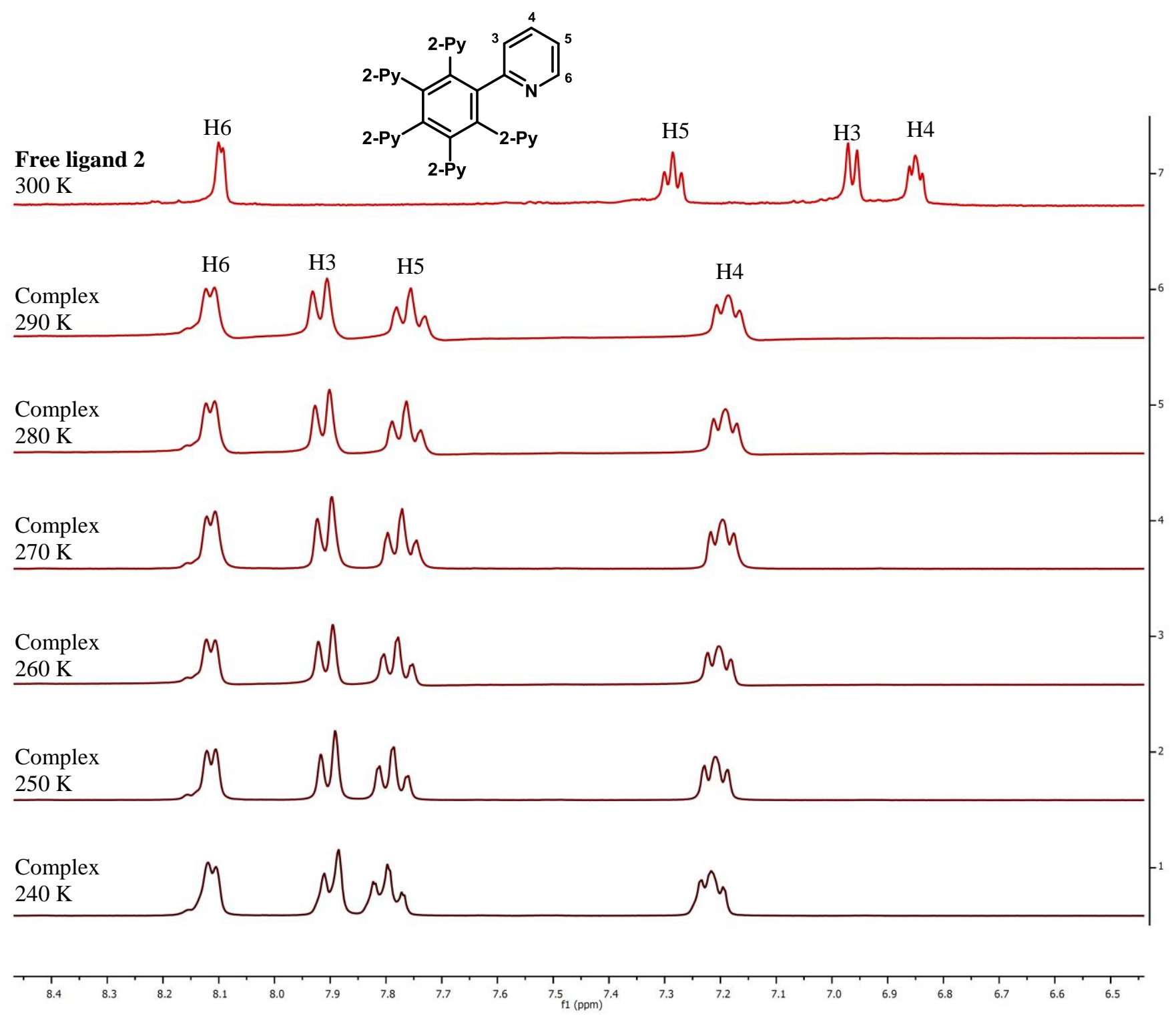

Figure S2: Stacked ${ }^{1} \mathrm{HNMR}\left(300 \mathrm{MHz}\right.$, acetone- $\left.d_{6}\right)$ spectra of the complex $\left[\mathrm{Ag}_{4} \mathrm{~F}(\mathbf{2})_{2}\right](\mathrm{OTf})_{3}$ and free ligand 2 at different temperatures (240-300 K). 
$300 \mathrm{~K}$

Complex

$M$ $M^{2} M$

$310 \mathrm{~K}$

$M$

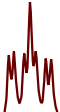

$320 \mathrm{~K}$

Complex

NA

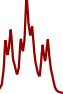

$330 \mathrm{~K}$

Complex

$\mu$
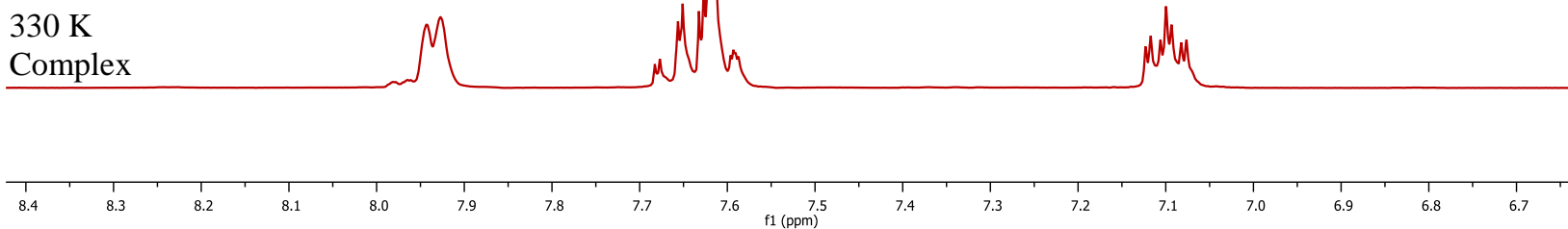

Figure S3: Stacked ${ }^{1} \mathrm{HNMR}\left(300 \mathrm{MHz}, \mathrm{CD}_{3} \mathrm{CN}\right)$ spectra of the complex $\left[\mathrm{Ag}_{4} \mathrm{~F}(\mathbf{2})_{2}\right](\mathrm{OTf})_{3}$ upon heating $(300-330$ $\mathrm{K})$. 


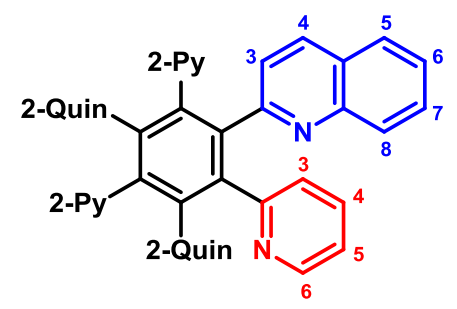

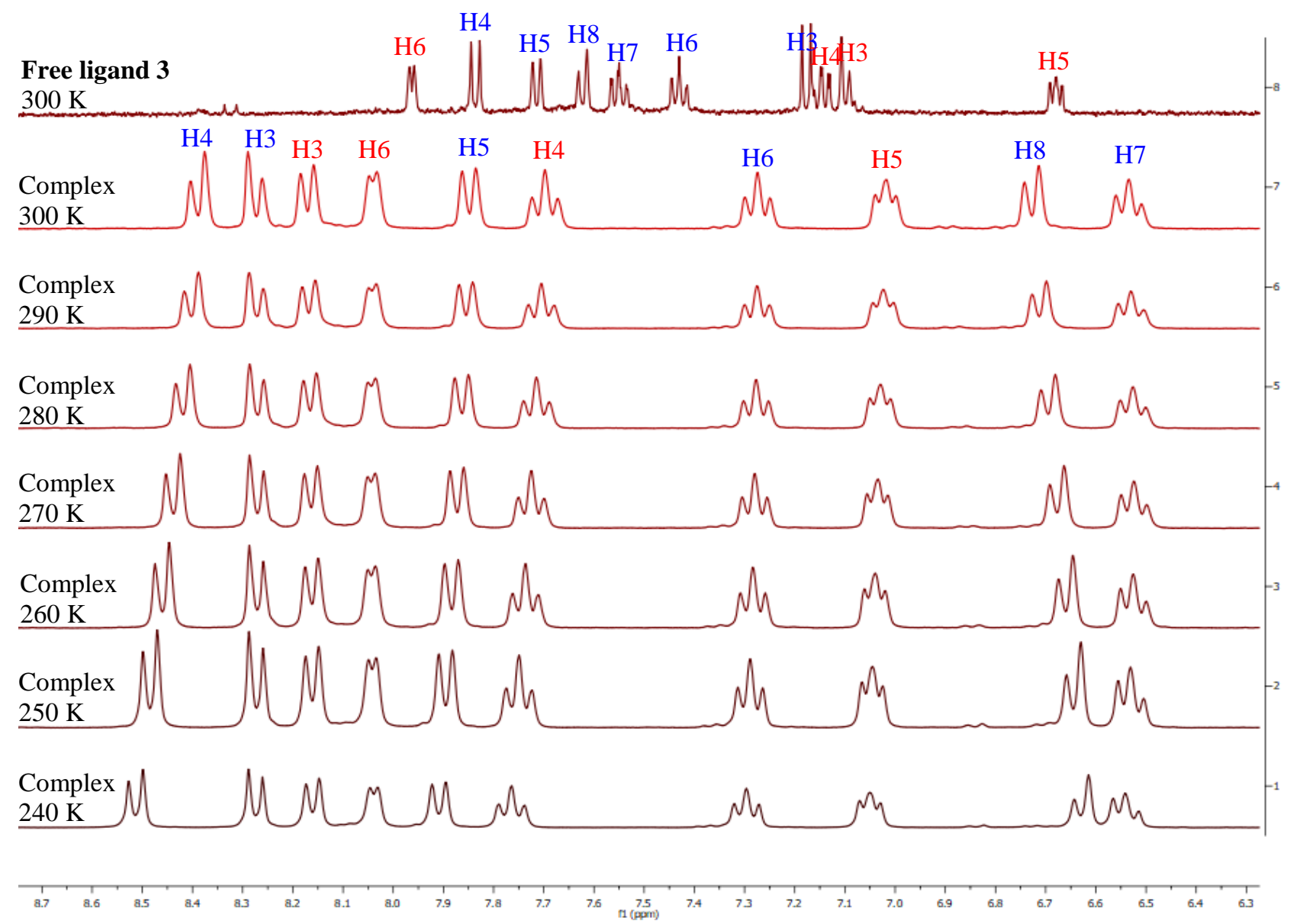

Figure S4: Stacked ${ }^{1} \mathrm{HNMR}\left(300 \mathrm{MHz}\right.$, acetone- $\left.d_{6}\right)$ spectra of the complex $\left[\mathrm{Ag}_{4} \mathrm{~F}(\mathbf{3})_{2}\right](\mathrm{OTf})_{3}$ and free ligand 3 at different temperatures (240-300 K). 


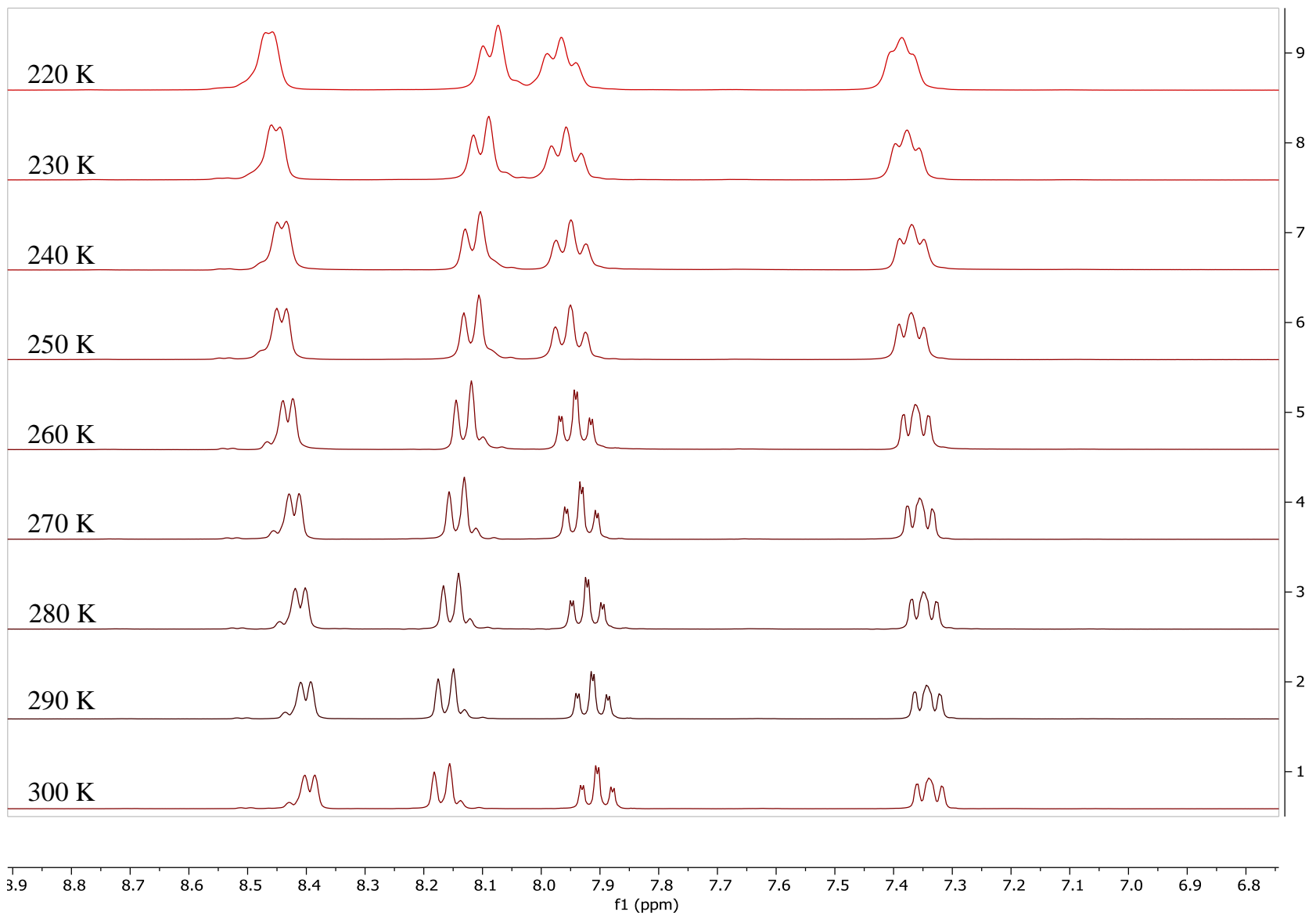

Figure S5: Stacked ${ }^{1} \mathrm{HNMR}\left(300 \mathrm{MHz}\right.$, acetone- $\left.d_{6}\right)$ spectra of the complex $\left[\mathrm{Ag}_{5} \mathrm{~F}(\mathbf{2})_{2}\right](\mathrm{OTf})_{4}$ at different temperatures $(220-300 \mathrm{~K})$. 


\section{NMR spectra}

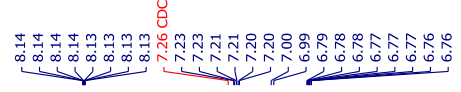<smiles>c1ccc(-c2c(-c3ccccn3)c(-c3ccccn3)c(-c3ccccn3)c(-c3ccccn3)c2-c2ccccn2)nc1</smiles>

2
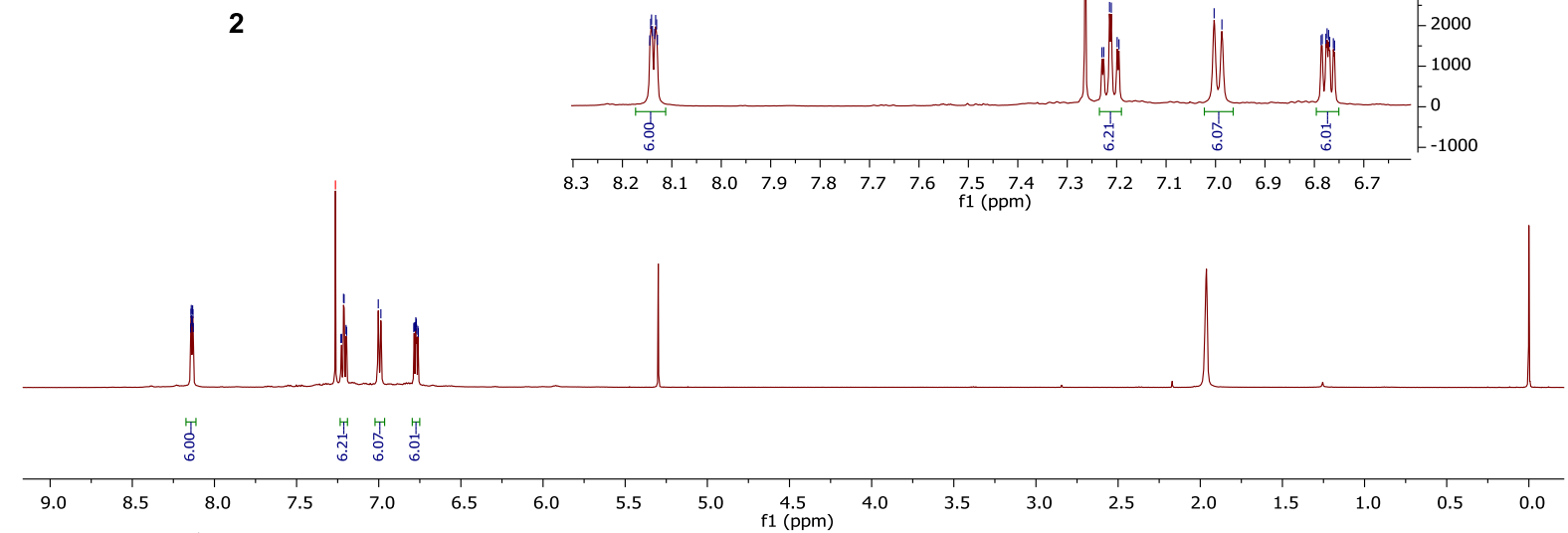

Figure S6: ${ }^{1} \mathrm{H}$ NMR spectrum $(500 \mathrm{MHz})$ of ligand 2 in $\mathrm{CDCl}_{3}$ at $296 \mathrm{~K}$.

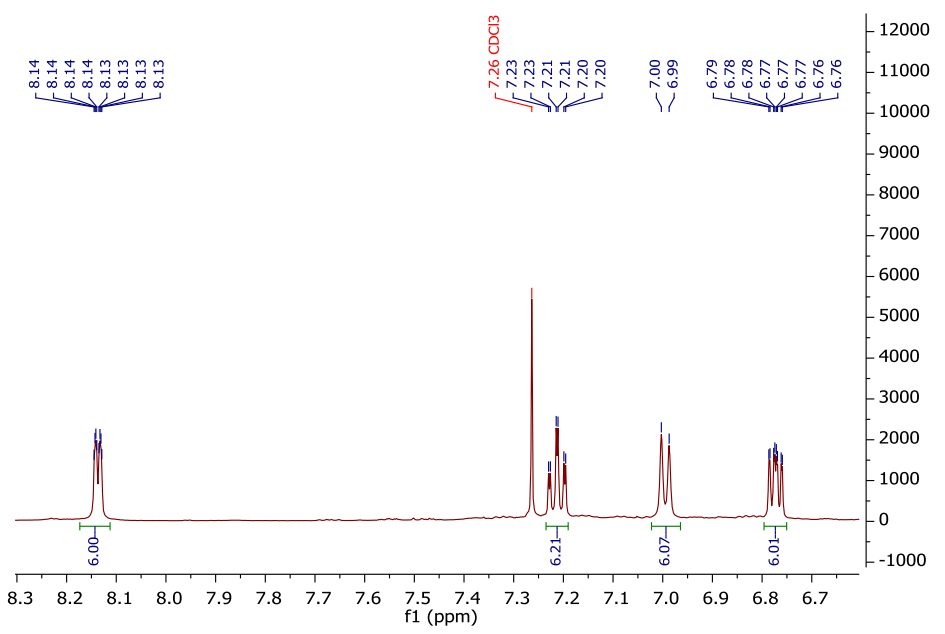

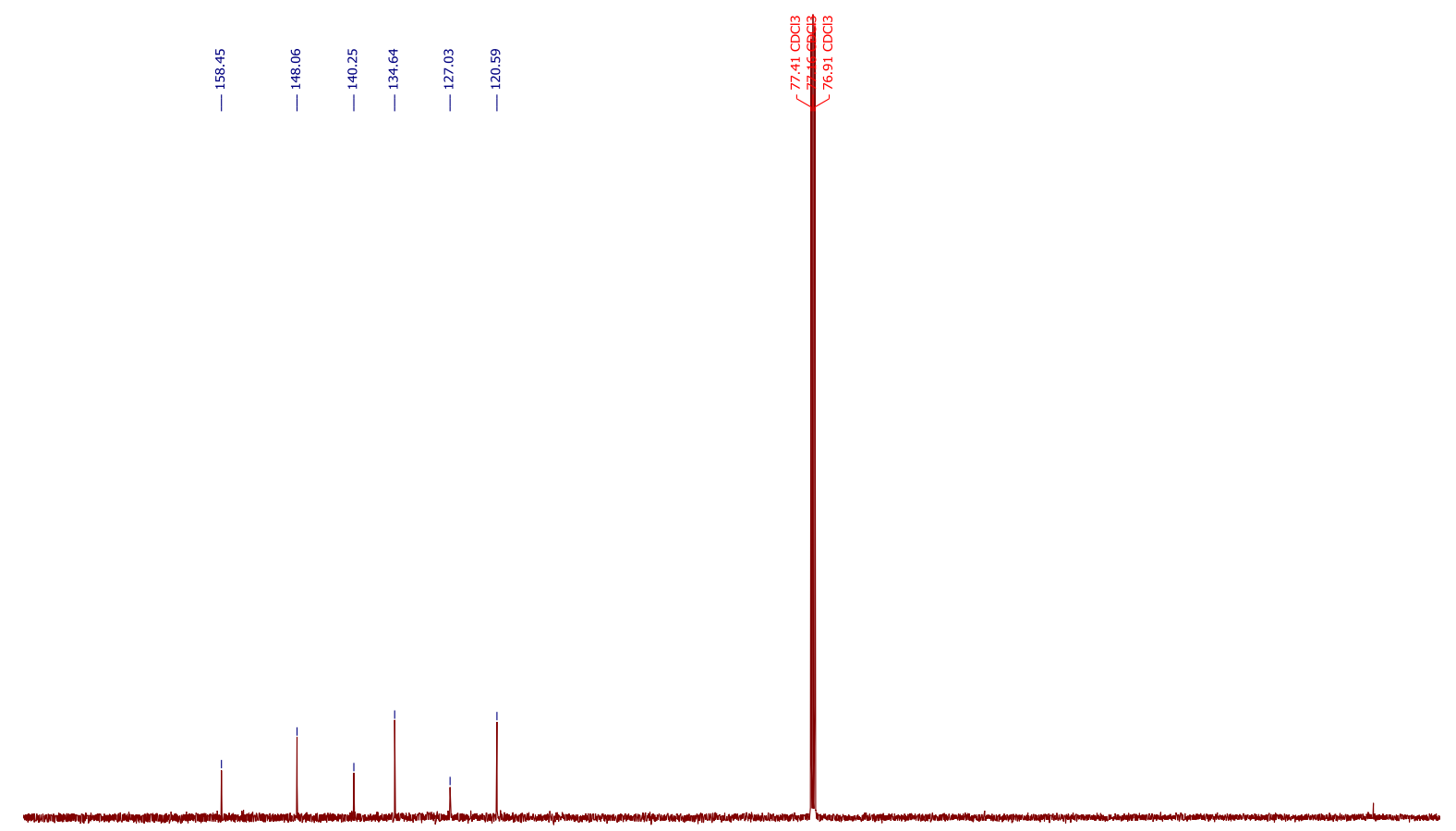

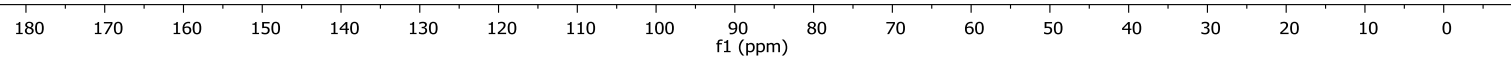

Figure S7: ${ }^{13} \mathrm{C}$ NMR spectrum $(126 \mathrm{MHz})$ of ligand 2 in $\mathrm{CDCl}_{3}$ at $296 \mathrm{~K}$. 
<smiles>c1ccc(-c2c(-c3ccccn3)c(-c3ccccn3)c(-c3ccc4ccccc4n3)c(-c3ccccn3)c2-c2ccccn2)nc1</smiles>

3

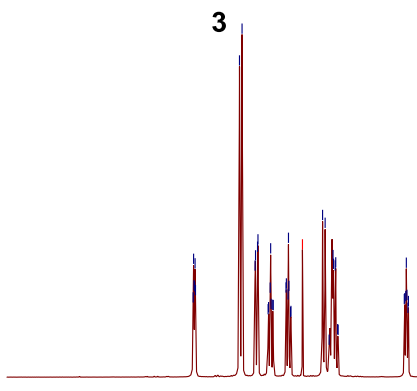

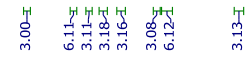
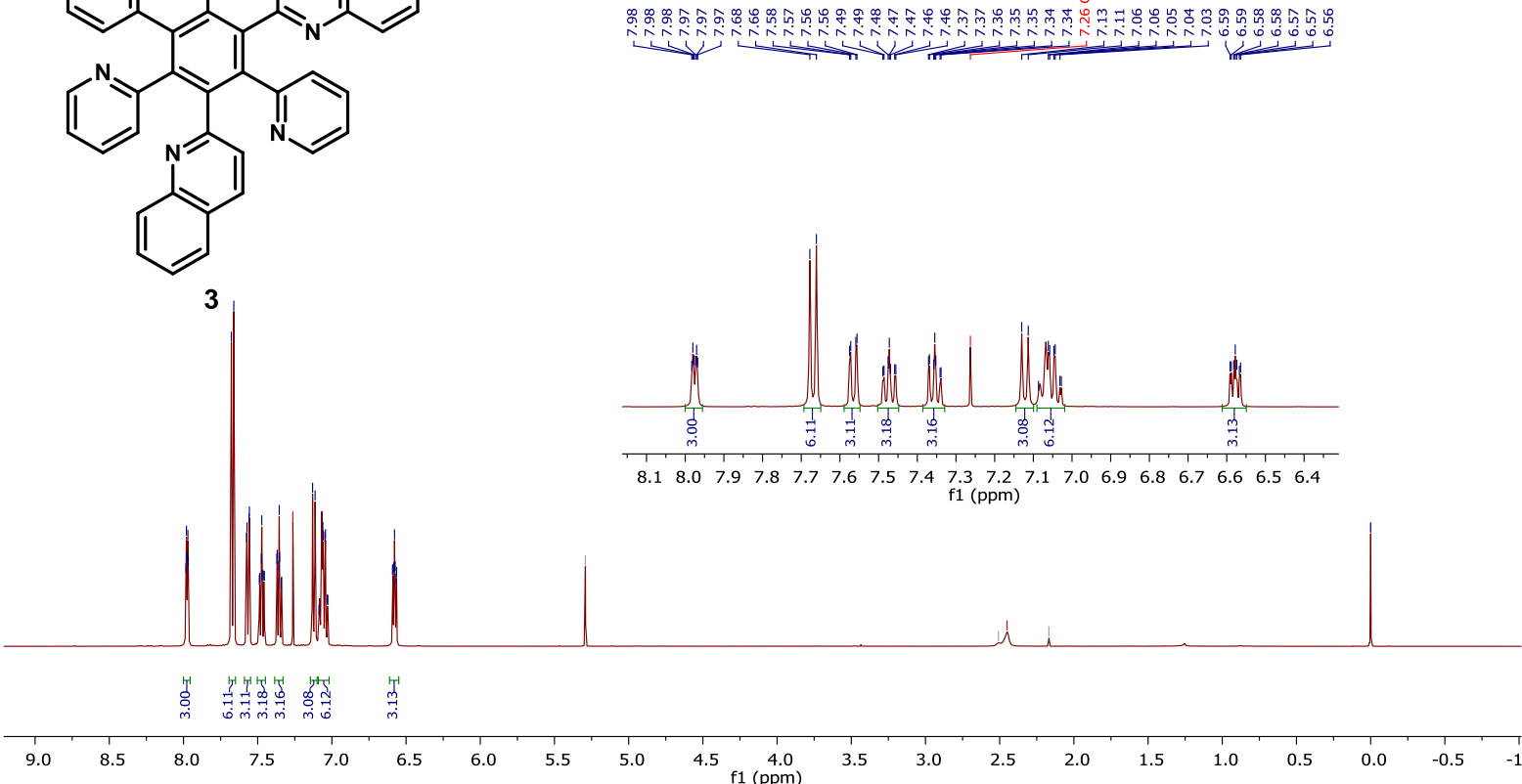

Figure S8: ${ }^{1} \mathrm{H}$ NMR spectrum $(500 \mathrm{MHz})$ of ligand 3 in $\mathrm{CDCl}_{3}$ at $296 \mathrm{~K}$.
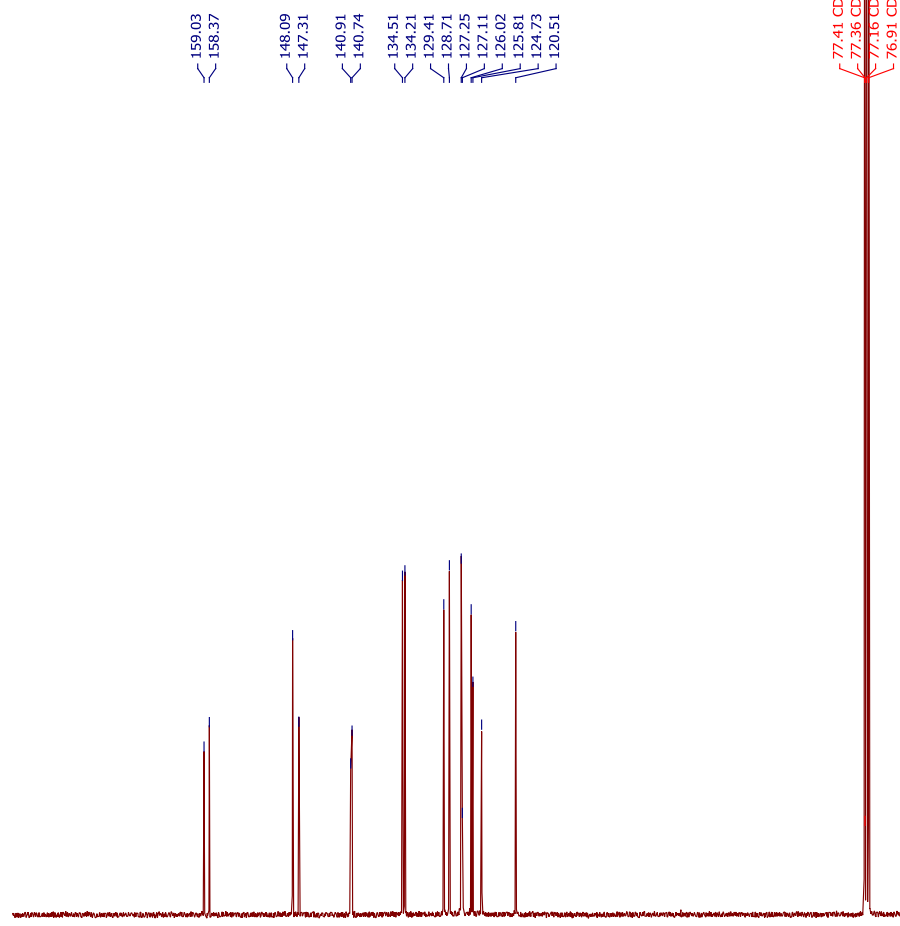

$\begin{array}{llllllllll}180 & 170 & 160 & 150 & 140 & 130 & 120 & 110 & 100 & \substack{90 \\ \mathrm{f} 1(\mathrm{ppm})}\end{array}$

Figure S9: ${ }^{13} \mathrm{C}$ NMR spectrum $(126 \mathrm{MHz})$ of ligand 3 in $\mathrm{CDCl}_{3}$ at $296 \mathrm{~K}$. 


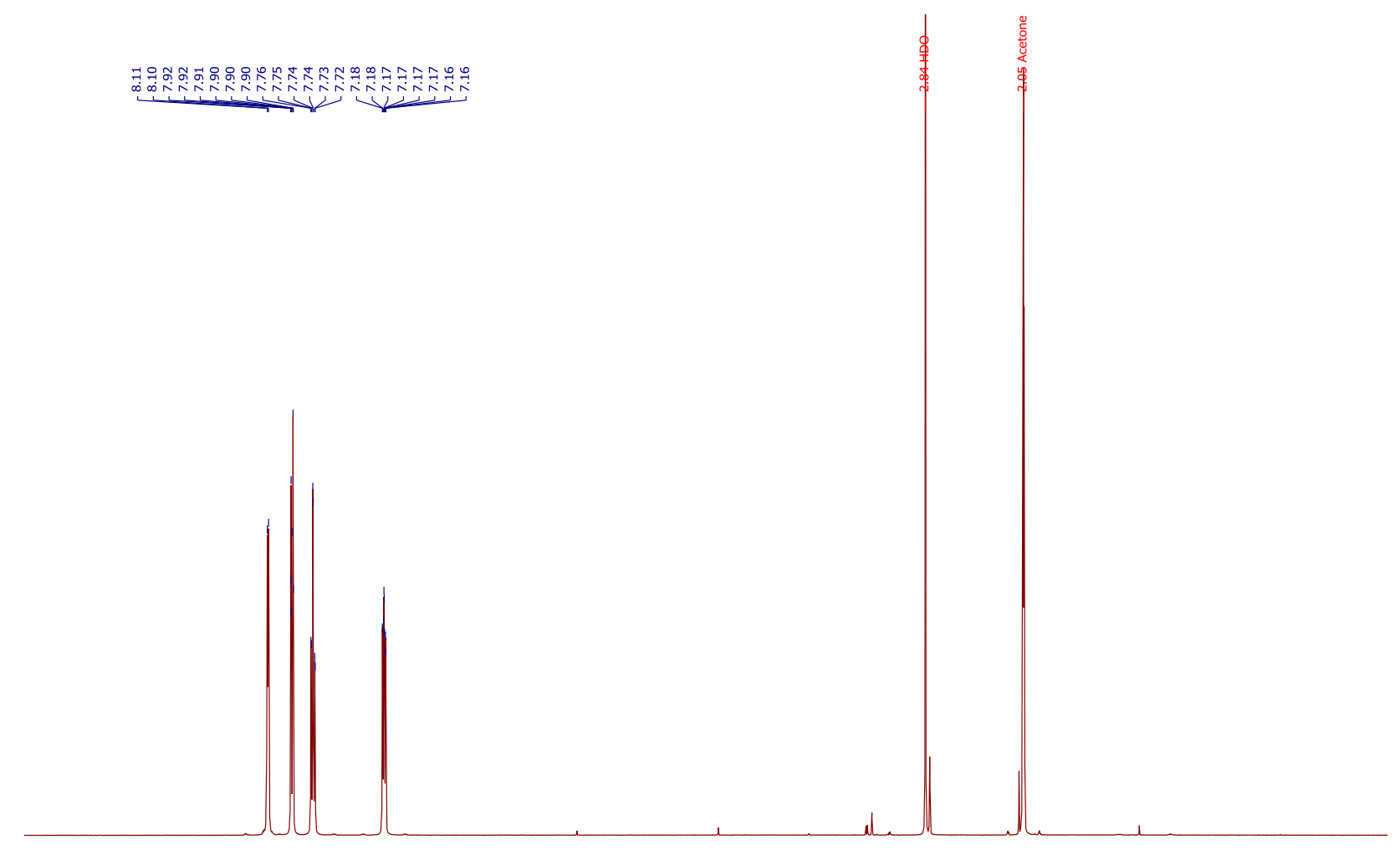

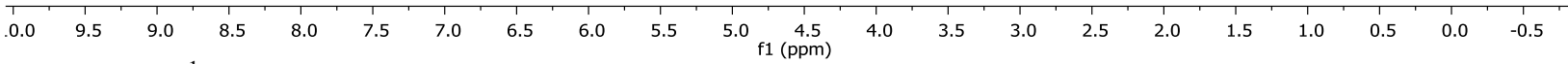

Figure S10: ${ }^{1} \mathrm{H}$ NMR spectrum $(500 \mathrm{MHz})$ of $\left[\mathrm{Ag}_{4} \mathrm{~F}(\mathbf{2})_{2}\right](\mathrm{OTf})_{3}$ in acetone- $d_{6}$ at $296 \mathrm{~K}$.

$$
\text { | }
$$
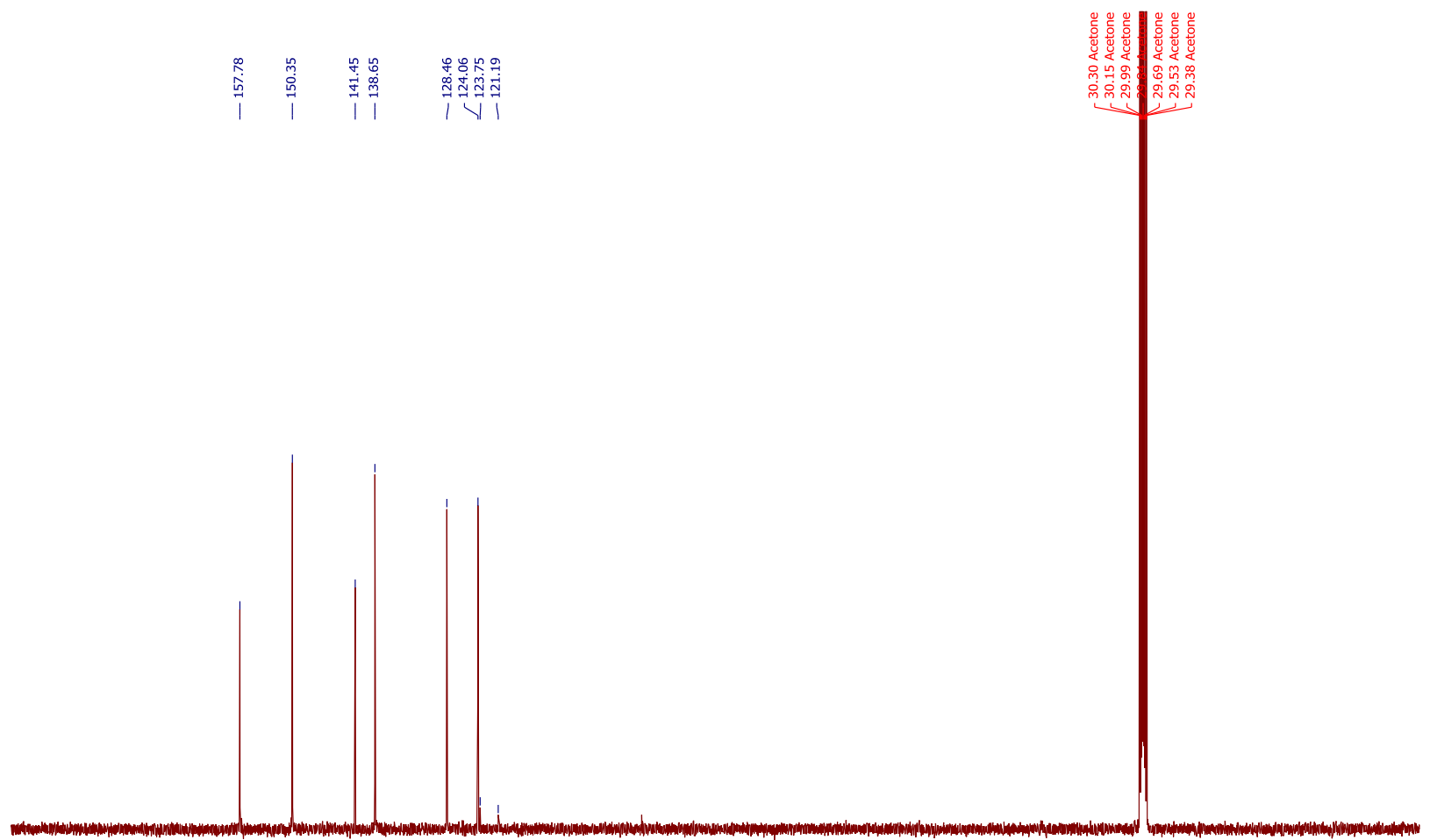

Figure S11: ${ }^{13} \mathrm{C}$ NMR spectrum $(126 \mathrm{MHz})$ of $\left[\mathrm{Ag}_{4} \mathrm{~F}(\mathbf{2})_{2}\right](\mathrm{OTf})_{3}$ in acetone- $d_{6}$ at $296 \mathrm{~K}$. 


\section{$\underset{\substack { 0 \\ \begin{subarray}{c}{i \\ i{ 0 \\ \begin{subarray} { c } { i \\ i } }\end{subarray}}{\substack{n \\ i}}$}

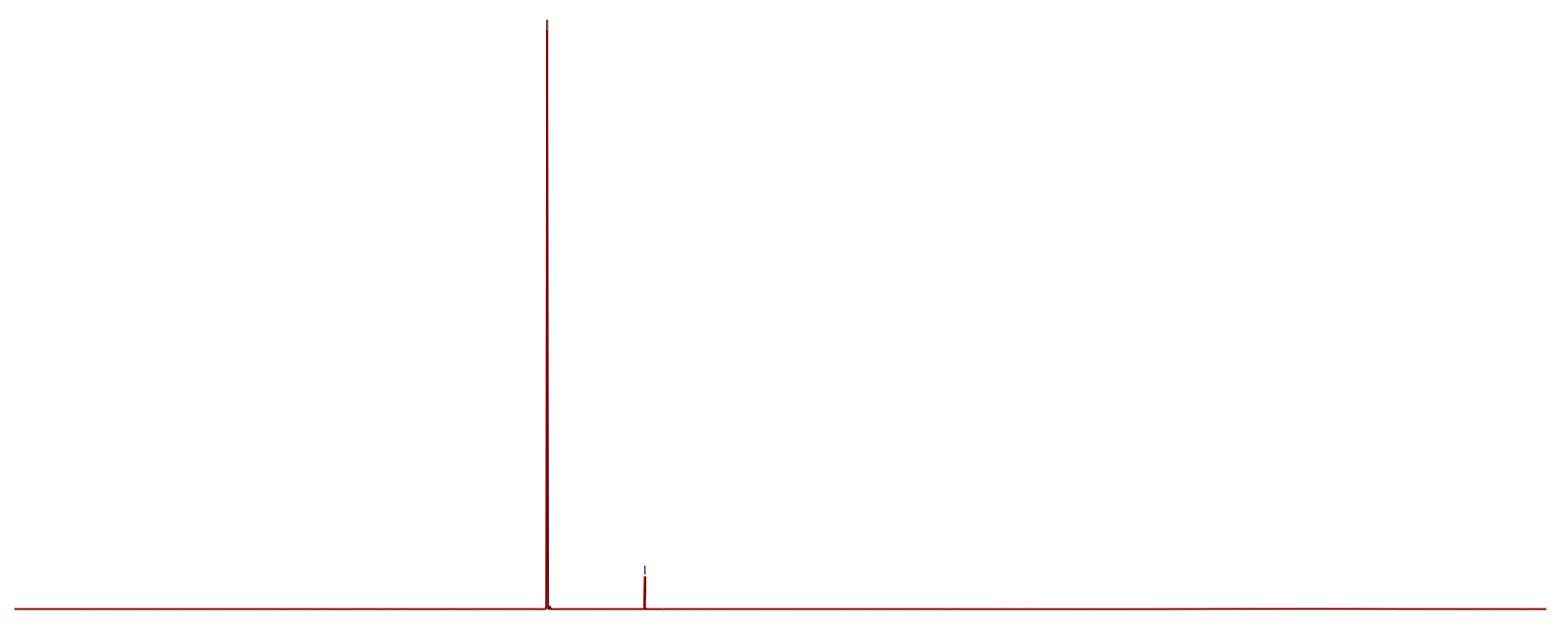

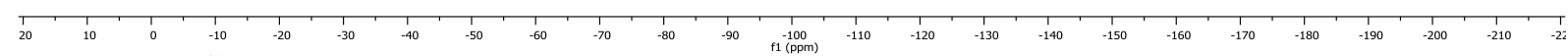

Figure S12: ${ }^{19} \mathrm{~F}$ NMR spectrum $(471 \mathrm{MHz})$ of $\left[\mathrm{Ag}_{4} \mathrm{~F}(\mathbf{2}){ }_{2}\right](\mathrm{OTf})_{3}$ in acetone- $d_{6}$ at $296 \mathrm{~K}$ (spectral window from 20 to $-220 \mathrm{ppm}$ ) showing signal for OTf (signal at -63.2 corresponds to $\mathrm{PhCF}_{3}$ ).

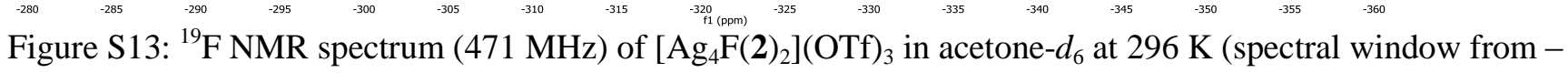
230 to $-470 \mathrm{ppm}$ ) showing signal for $\mathrm{F}^{-}$. 
1|

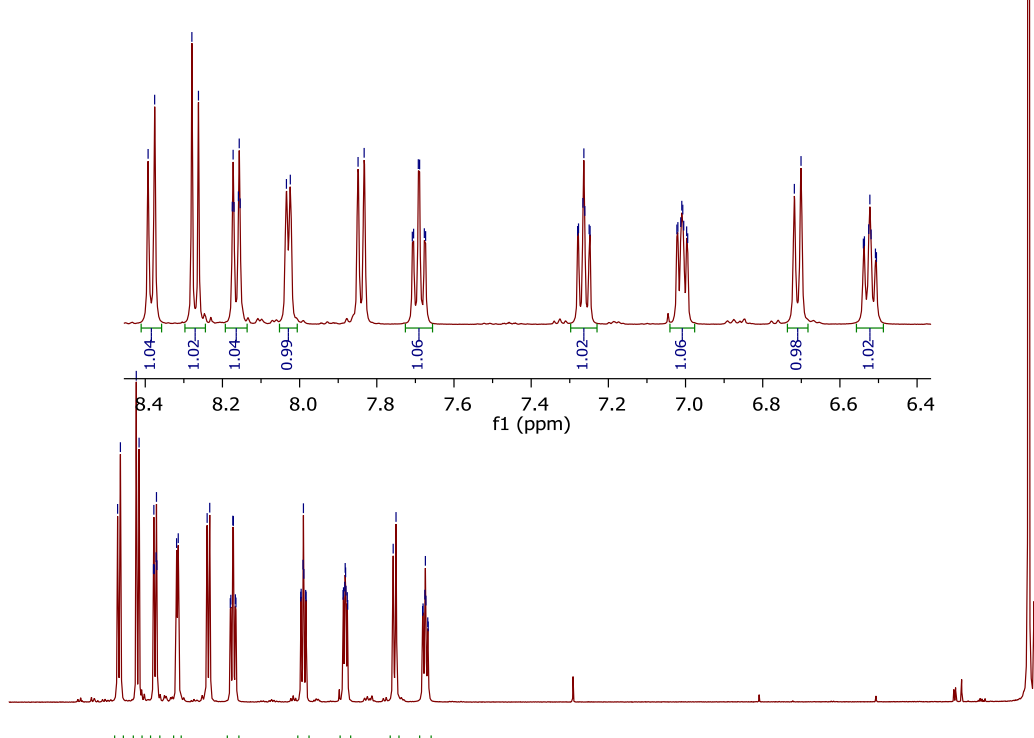

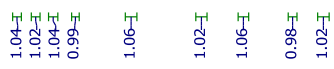

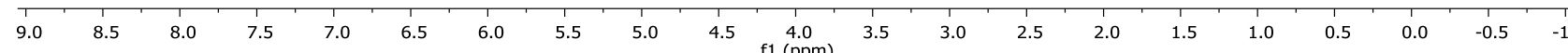

Figure S14: ${ }^{1} \mathrm{H}$ NMR spectrum $(500 \mathrm{MHz})$ of $\left[\mathrm{Ag}_{4} \mathrm{~F}(\mathbf{3})_{2}\right](\mathrm{OTf})_{3}$ in acetone- $d_{6}$ at $296 \mathrm{~K}$.
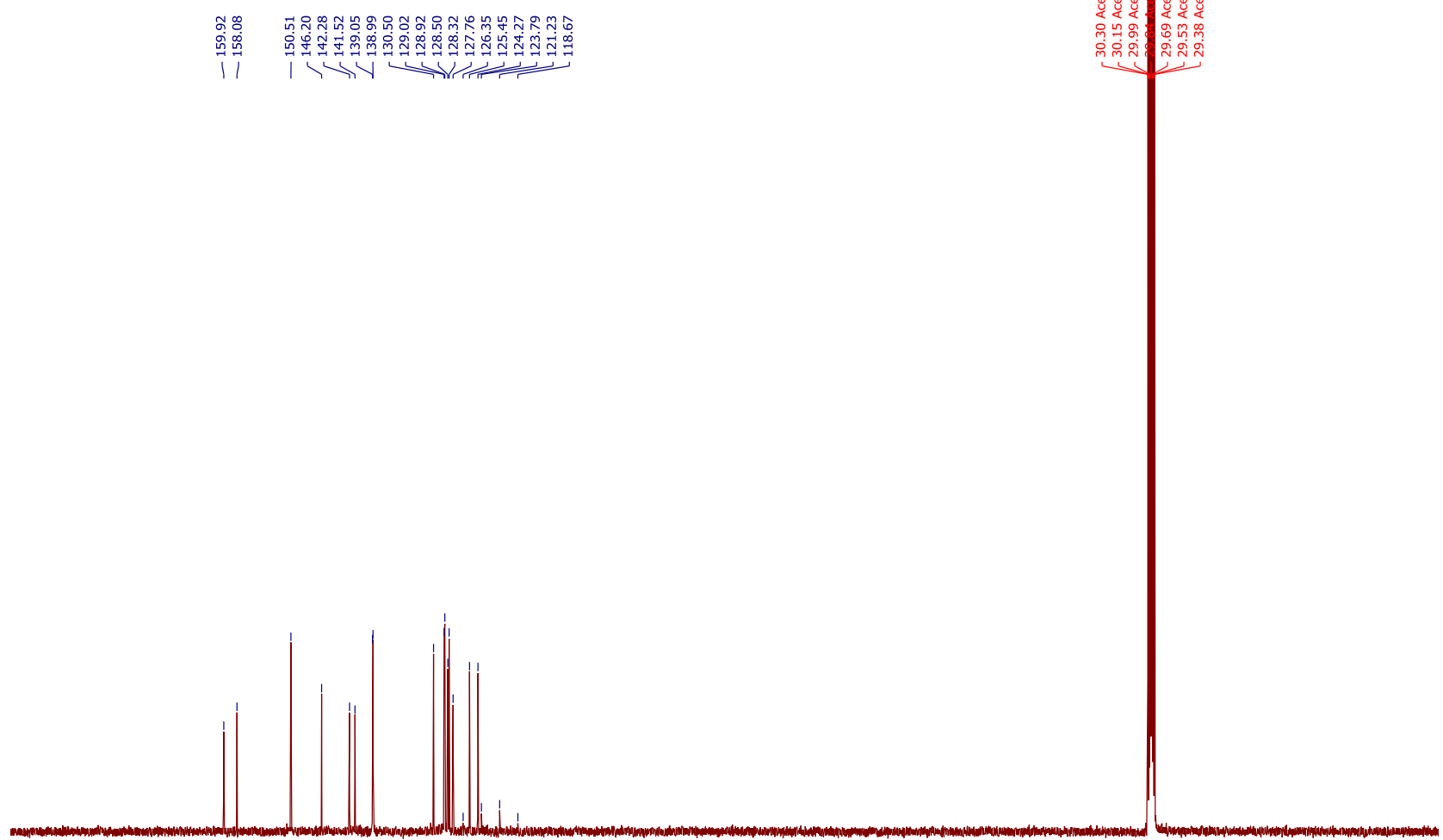

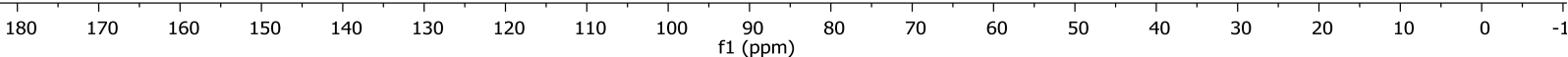

Figure $\mathrm{S} 15:{ }^{13} \mathrm{C}$ NMR spectrum $(126 \mathrm{MHz})$ of $\left[\mathrm{Ag}_{4} \mathrm{~F}(3)_{2}\right](\mathrm{OTf})_{3}$ in acetone- $d_{6}$ at $296 \mathrm{~K}$. 


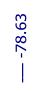

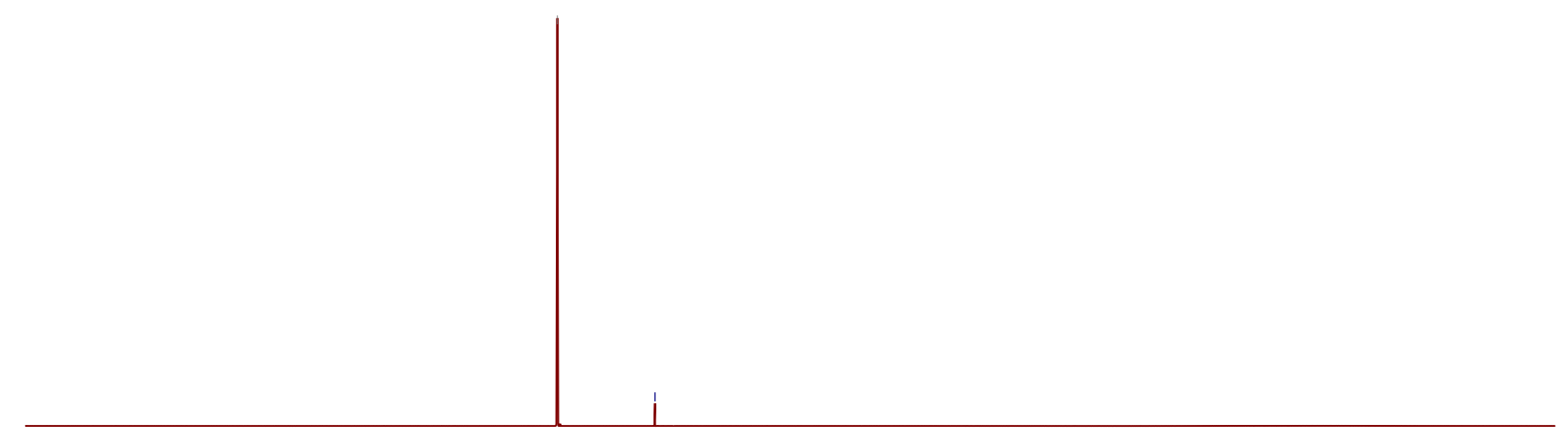

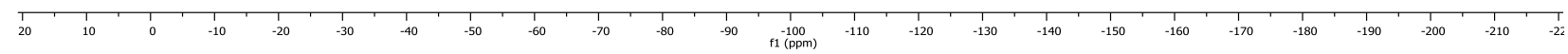

Figure S16: ${ }^{19} \mathrm{~F}$ NMR spectrum $(471 \mathrm{MHz})$ of $\left[\mathrm{Ag}_{4} \mathrm{~F}(\mathbf{3})_{2}\right](\mathrm{OTf})_{3}$ in acetone- $d_{6}$ at $296 \mathrm{~K}$ (spectral window from 20 to $-220 \mathrm{ppm}$ ) showing signal for OTf (signal at -63.2 corresponds to $\mathrm{PhCF}_{3}$ ).

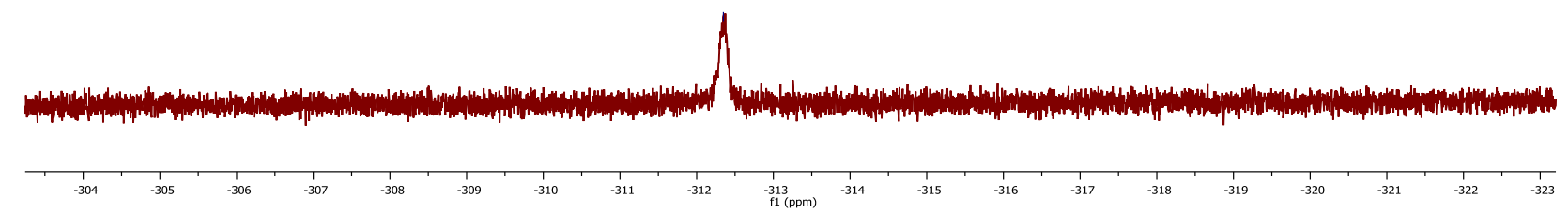

Figure S17: ${ }^{19} \mathrm{~F}$ NMR spectrum $(471 \mathrm{MHz})$ of $\left[\mathrm{Ag}_{4} \mathrm{~F}(3)_{2}\right](\mathrm{OTf})_{3}$ in acetone- $d_{6}$ at $296 \mathrm{~K}$ (spectral window from 230 to $-470 \mathrm{ppm}$ ) showing signal for $\mathrm{F}^{-}$. 


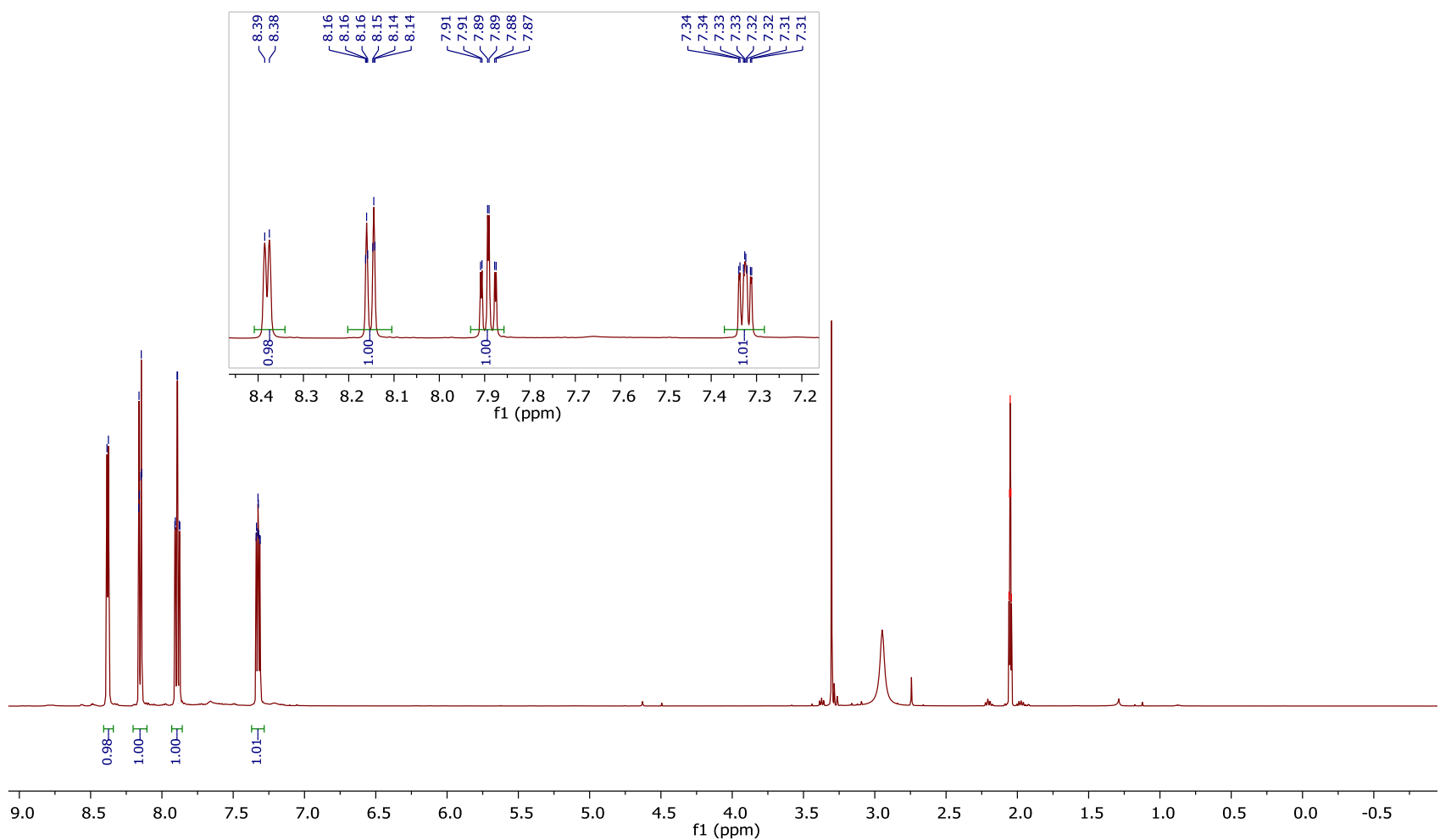

Figure S18: ${ }^{1} \mathrm{H}$ NMR spectrum $(500 \mathrm{MHz})$ of $\left[\mathrm{Ag}_{5} \mathrm{~F}(\mathbf{2})_{2}\right](\mathrm{OTf})_{4}$ in acetone- $d_{6}$ at $296 \mathrm{~K}$.
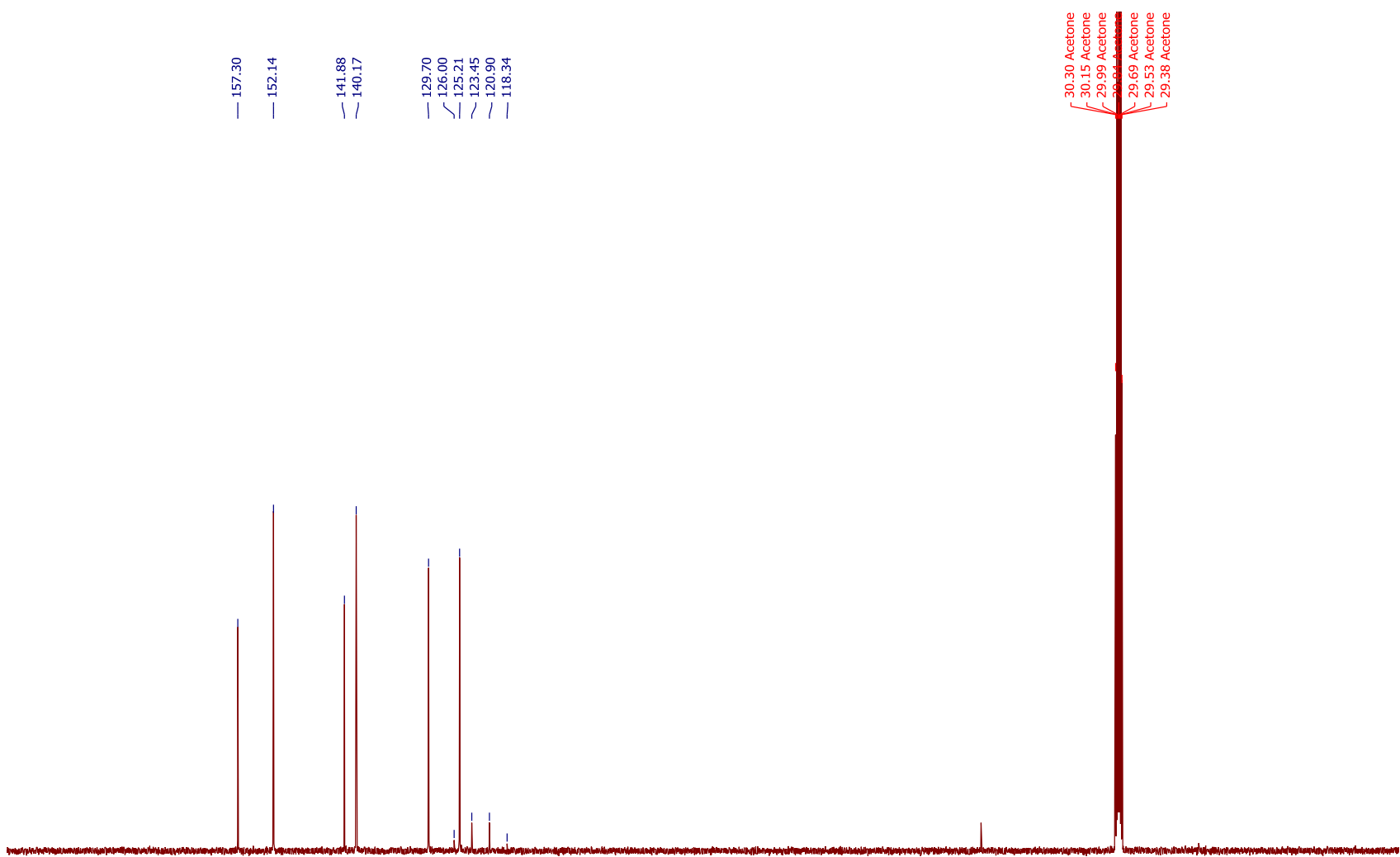

Figure S19: ${ }^{13} \mathrm{C}$ NMR spectrum $(126 \mathrm{MHz})$ of $\left[\mathrm{Ag}_{5} \mathrm{~F}(\mathbf{2})_{2}\right](\mathrm{OTf})_{4}$ in acetone- $d_{6}$ at $296 \mathrm{~K}$. 


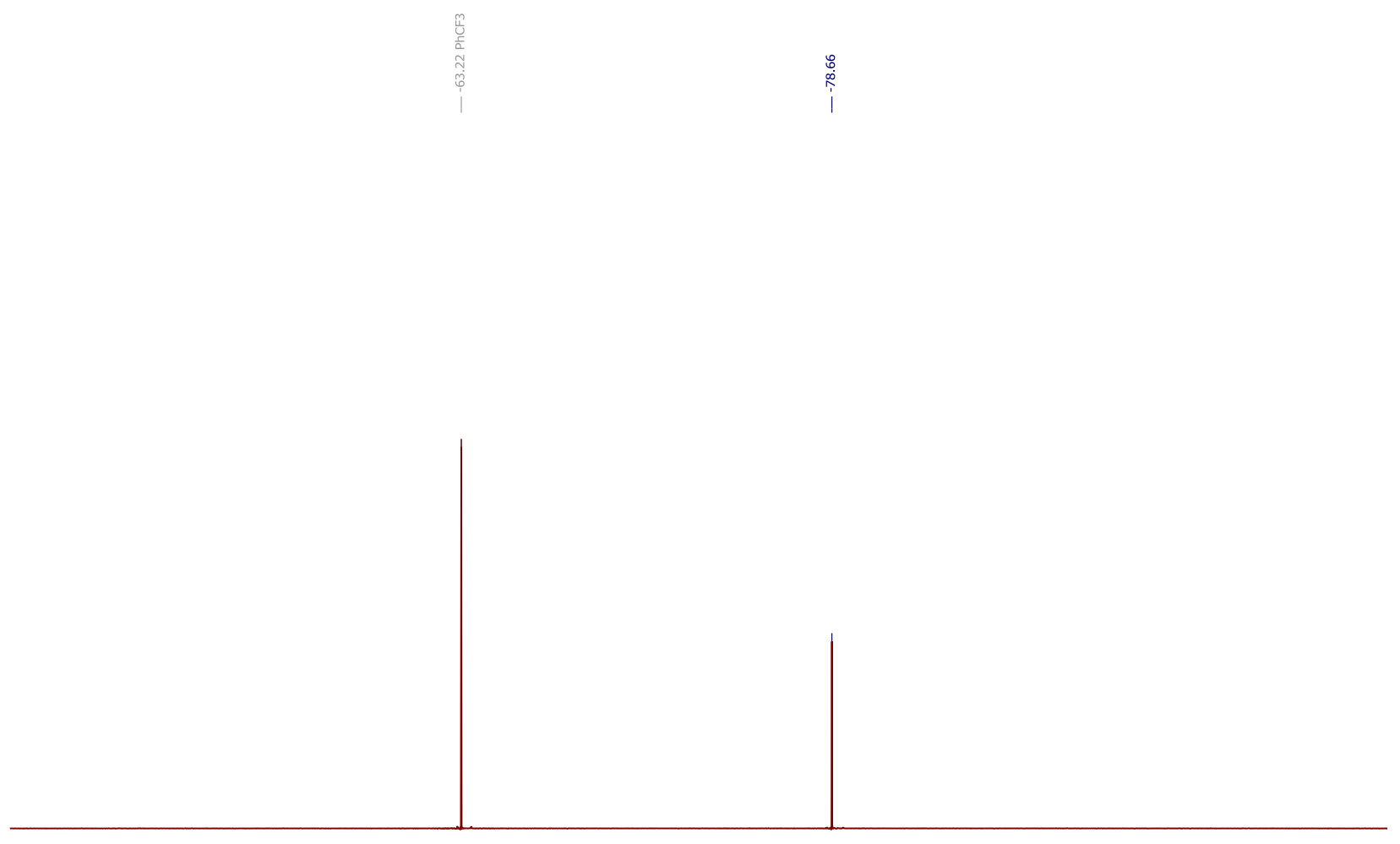

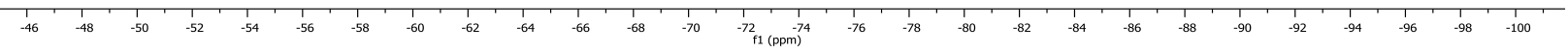

Figure S20: ${ }^{19} \mathrm{~F}$ NMR spectrum $(471 \mathrm{MHz})$ of $\left[\mathrm{Ag}_{5} \mathrm{~F}(2)_{2}\right](\mathrm{OTf})_{4}$ in acetone- $d_{6}$ at $296 \mathrm{~K}$ (spectral window from 20 to $-220 \mathrm{ppm}$ ) showing signal for OTf (signal at -63.2 corresponds to $\mathrm{PhCF}_{3}$ ).

$$
\text { 䓌 }
$$

$\mid$

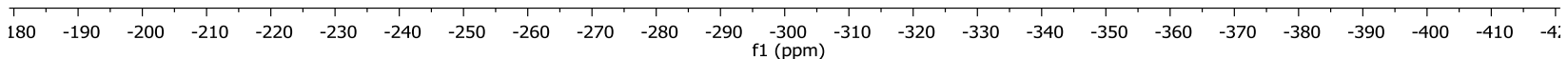

Figure $\mathrm{S} 21:{ }^{19} \mathrm{~F}$ NMR spectrum $(471 \mathrm{MHz})$ of $\left[\mathrm{Ag}_{5} \mathrm{~F}(\mathbf{2})_{2}\right](\mathrm{OTf})_{4}$ in acetone- $d_{6}$ at $296 \mathrm{~K}$ (spectral window from 230 to $-470 \mathrm{ppm}$ ) showing signal for $\mathrm{F}^{-}$. 


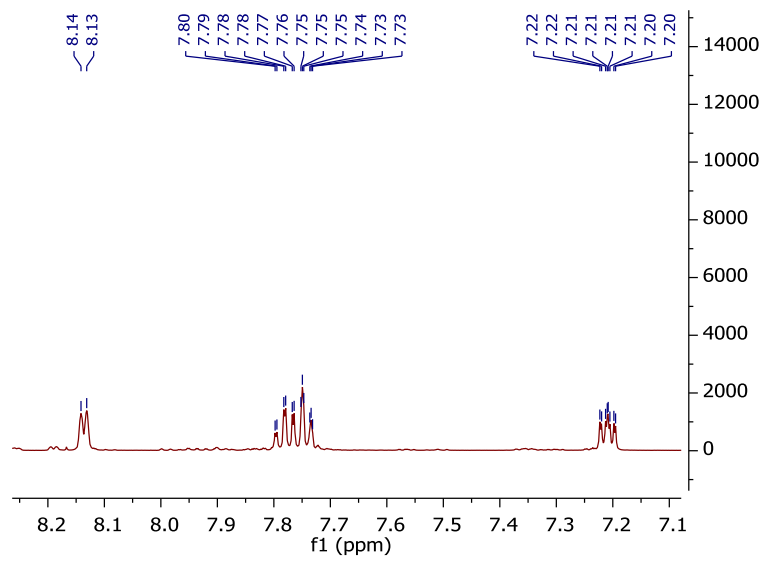

$\begin{array}{llllllllllll}8.2 & 8.1 & 8.0 & 7.9 & 7.8 & \begin{array}{c}7.7 \\ \mathrm{f} 1(\mathrm{ppm})\end{array} & 7.6 & 7.5 & 7.4 & 7.3 & 7.2 & 7.1\end{array}$

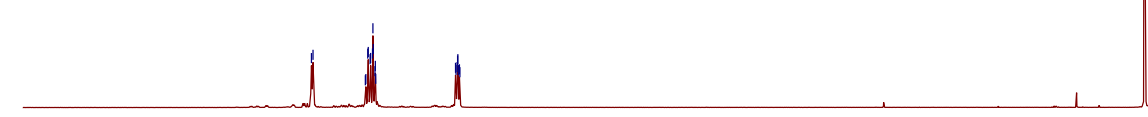

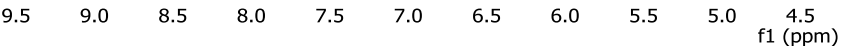

Figure S22: ${ }^{1} \mathrm{H}$ NMR spectrum $(500 \mathrm{MHz})$ of $\left[\mathrm{Ag}_{4} \mathrm{~F}(2)_{2}\right]\left(\mathrm{PF}_{6}\right)_{3}$ in acetone- $d_{6}$ at $296 \mathrm{~K}$.

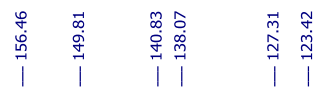

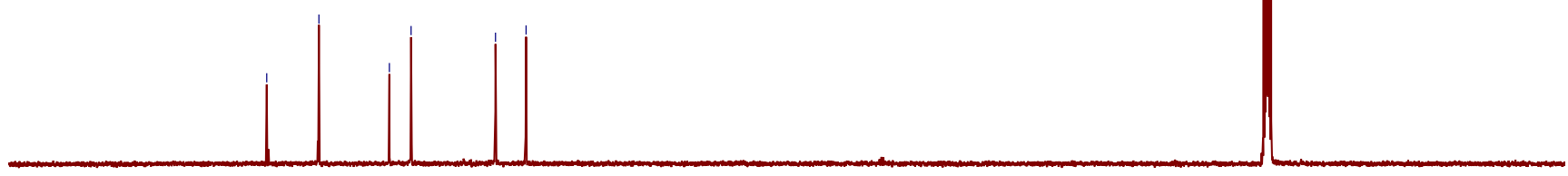

Figure S23: ${ }^{13} \mathrm{C}$ NMR spectrum $(126 \mathrm{MHz})$ of $\left[\mathrm{Ag}_{4} \mathrm{~F}(2)_{2}\right]\left(\mathrm{PF}_{6}\right)_{3}$ in acetone- $d_{6}$ at $296 \mathrm{~K}$. 

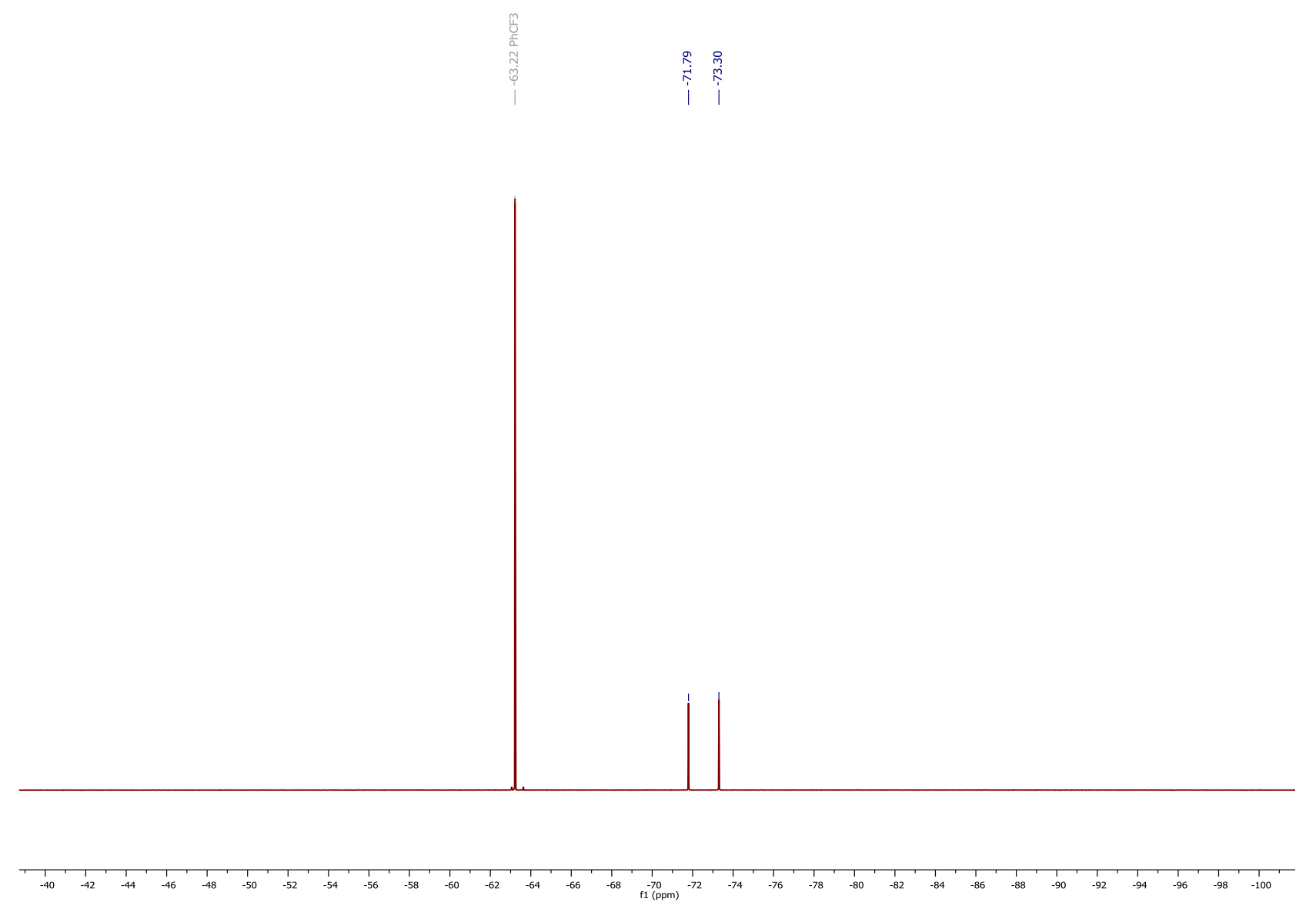

Figure S24: ${ }^{19} \mathrm{~F}$ NMR spectrum $(471 \mathrm{MHz})$ of $\left[\mathrm{Ag}_{4} \mathrm{~F}(2)_{2}\right]\left(\mathrm{PF}_{6}\right)_{3}$ in acetone- $d_{6}$ at $296 \mathrm{~K}$ (spectral window from 20 to $-220 \mathrm{ppm}$ ) showing signal for $\mathrm{PF}_{6}\left(\mathrm{~d},{ }^{1} J_{\mathrm{FP}}=708.2 \mathrm{~Hz}\right)$ (signal at -63.2 corresponds to $\left.\mathrm{PhCF}_{3}\right)$.

Figure S25: ${ }^{19} \mathrm{~F}$ NMR spectrum $(471 \mathrm{MHz})$ of $\left[\mathrm{Ag}_{4} \mathrm{~F}(2)_{2}\right]\left(\mathrm{PF}_{6}\right)_{3}$ in acetone- $d_{6}$ at $296 \mathrm{~K}$ (spectral window from 230 to $-470 \mathrm{ppm}$ ) showing signal for $\mathrm{F}^{-}$. 


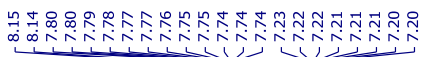

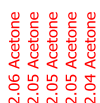

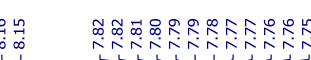
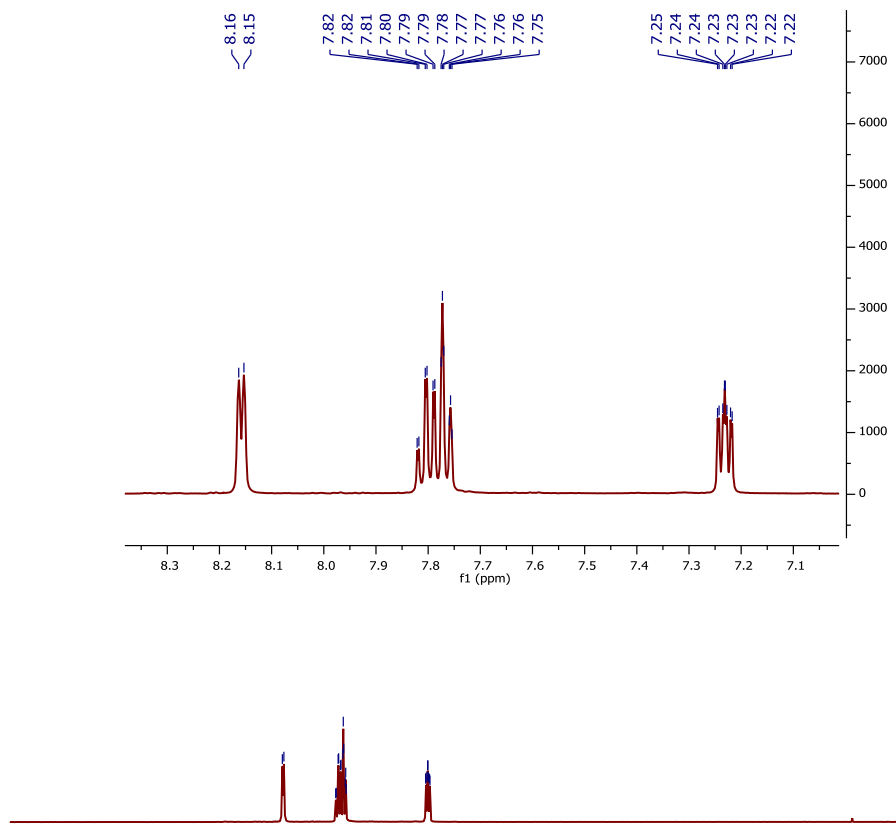

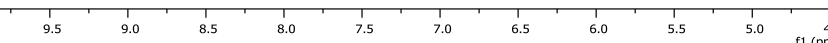

Figure S26: ${ }^{1} \mathrm{H}$ NMR spectrum $(500 \mathrm{MHz})$ of $\left[\mathrm{Ag}_{4} \mathrm{~F}(2)_{2}\right]\left(\mathrm{SbF}_{6}\right)_{3}$ in acetone- $d_{6}$ at $296 \mathrm{~K}$.

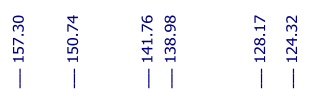

Figure S27: ${ }^{13} \mathrm{C}$ NMR spectrum $(126 \mathrm{MHz})$ of $\left[\mathrm{Ag}_{4} \mathrm{~F}(2)_{2}\right]\left(\mathrm{SbF}_{6}\right)_{3}$ in acetone- $d_{6}$ at $296 \mathrm{~K}$. 


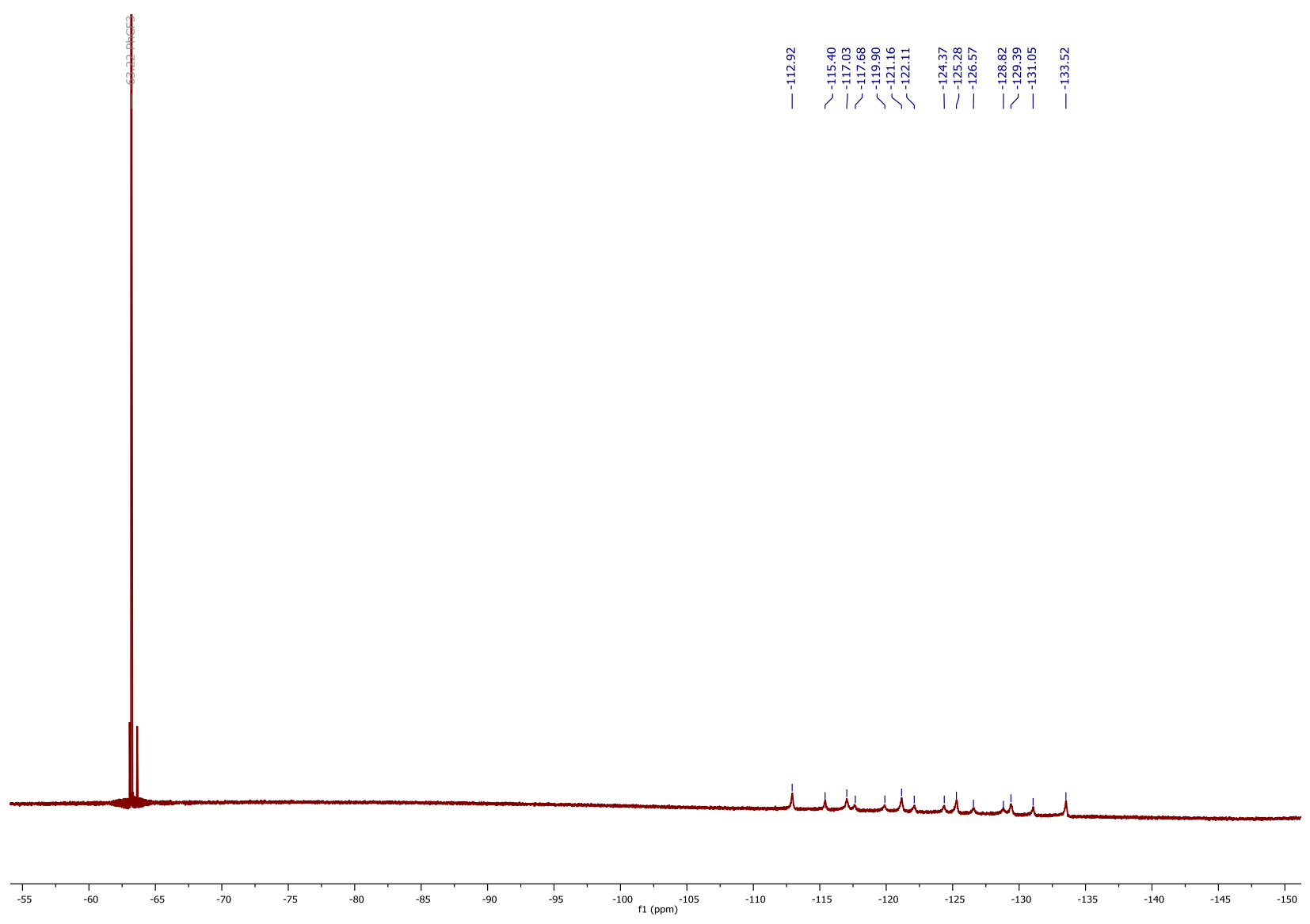

Figure S28: ${ }^{19} \mathrm{~F}$ NMR spectrum $(471 \mathrm{MHz})$ of $\left[\mathrm{Ag}_{4} \mathrm{~F}(2)_{2}\right]\left(\mathrm{SbF}_{6}\right)_{3}$ in acetone- $d_{6}$ at $296 \mathrm{~K}$ (spectral window from 20 to $-220 \mathrm{ppm}$ ) showing signals for $\mathrm{SbF}_{6}$ (superposition of a sextet due to ${ }^{121} \mathrm{SbF}_{6}{ }^{-}$and an octet due to ${ }^{123} \mathrm{SbF}_{6}{ }^{-}$, $\left.{ }^{1} J_{\mathrm{F}}^{121} \mathrm{Sb}=1941,{ }^{1} J_{\mathrm{F}}^{123} \mathrm{Sb}=1051 \mathrm{~Hz}\right)\left(\right.$ signal at -63.2 corresponds to $\left.\mathrm{PhCF}_{3}\right)$.

Figure S29: ${ }^{19} \mathrm{~F}$ NMR spectrum $(471 \mathrm{MHz})$ of $\left[\mathrm{Ag}_{4} \mathrm{~F}(2)_{2}\right]\left(\mathrm{SbF}_{6}\right)_{3}$ in acetone- $d_{6}$ at $296 \mathrm{~K}$ (spectral window from 230 to $-470 \mathrm{ppm})$ showing signal for $\mathrm{F}^{-}$. 


\section{Mass spectra}

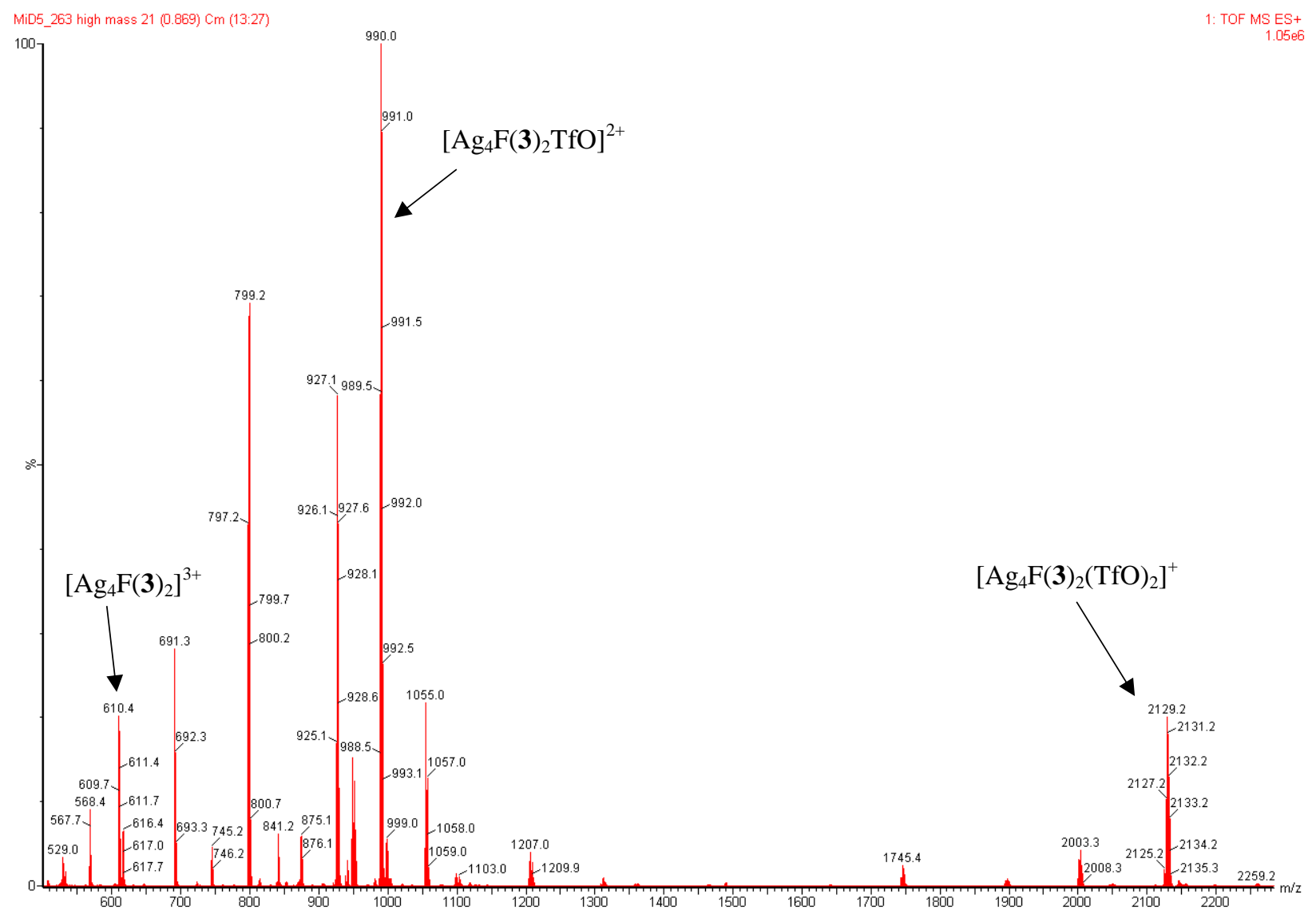

Figure S30: Mass spectrum (TOF-MS) of $\left[\mathrm{Ag}_{4} \mathrm{~F}(\mathbf{3})_{2}\right](\mathrm{OTf})_{3}$. 


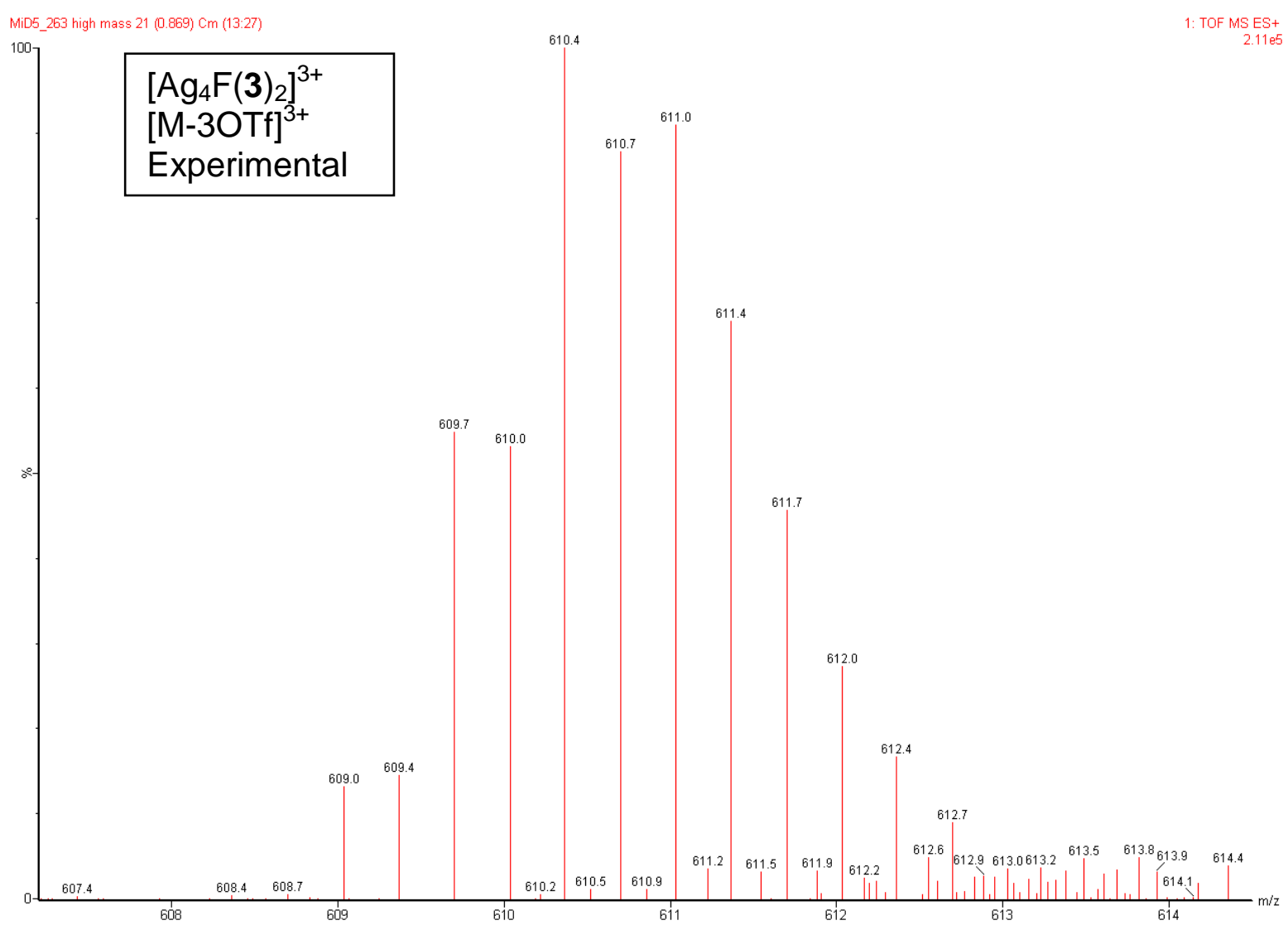

Figure S31: Mass spectrum (TOF-MS) peak corresponding to $\left[\mathrm{Ag}_{4} \mathrm{~F}(\mathbf{3})_{2}\right]^{3+}$.

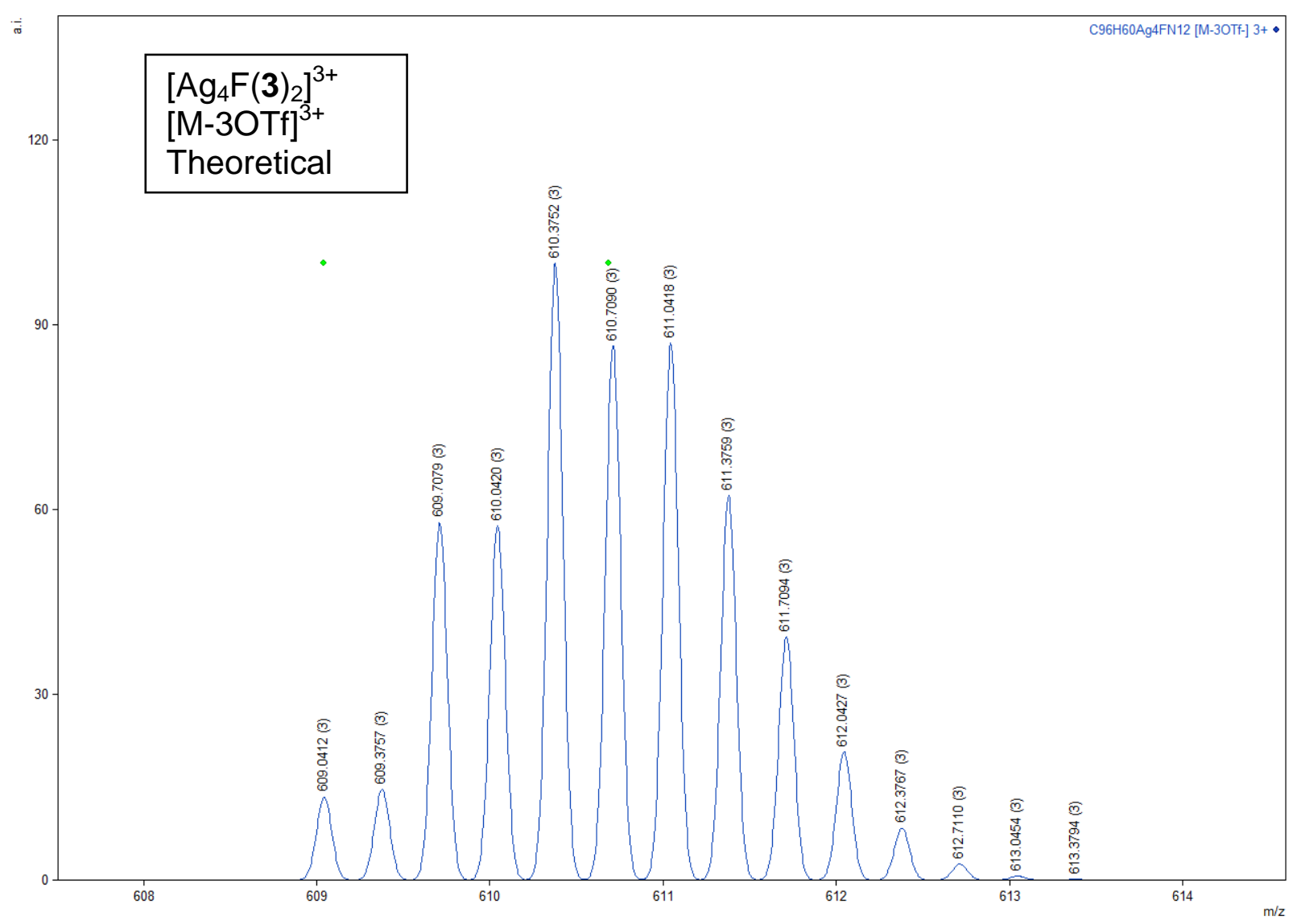

Figure S32: Simulated mass spectrum peak corresponding to $\left[\operatorname{Ag}_{4} \mathrm{~F}(3)_{2}\right]^{3+}$. 


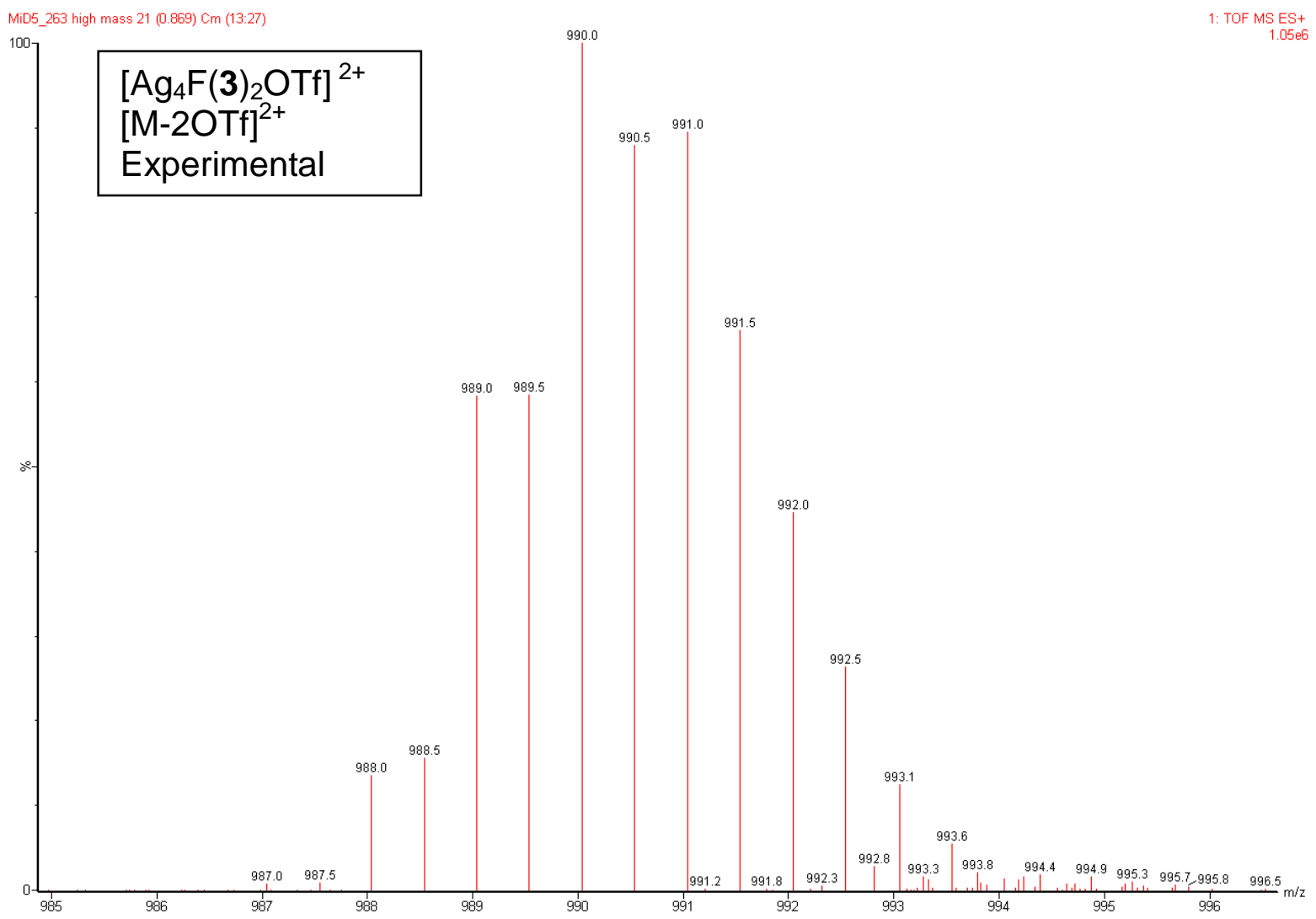

Figure S33: Mass spectrum (TOF-MS) peak corresponding to $\left[\mathrm{Ag}_{4} \mathrm{~F}(\mathbf{3})_{2} \mathrm{OTf}\right]^{2+}$.

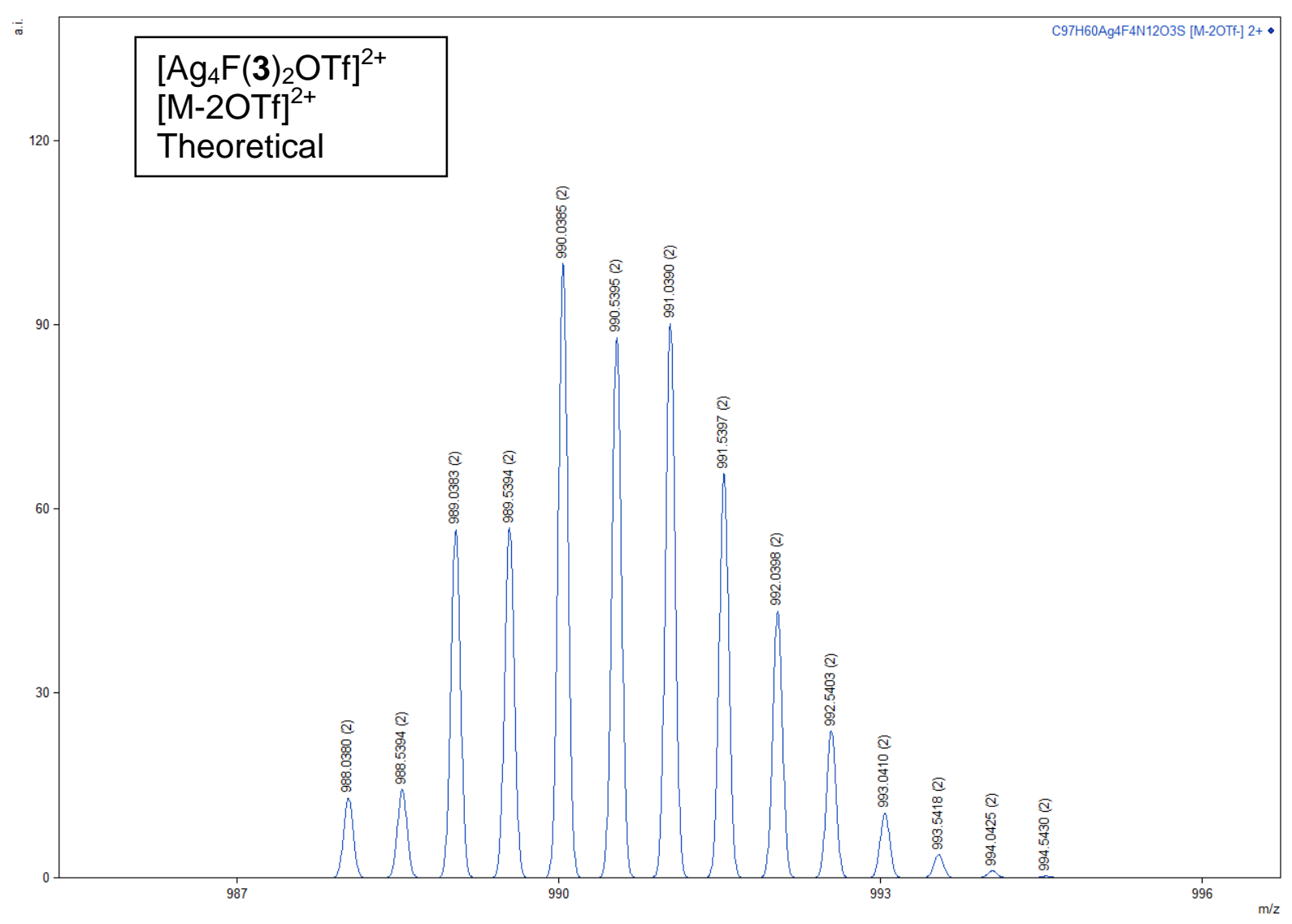

Figure S34: Simulated mass spectrum peak corresponding to $\left[\mathrm{Ag}_{4} \mathrm{~F}(\mathbf{3})_{2} \mathrm{OTf}\right]^{2+}$. 


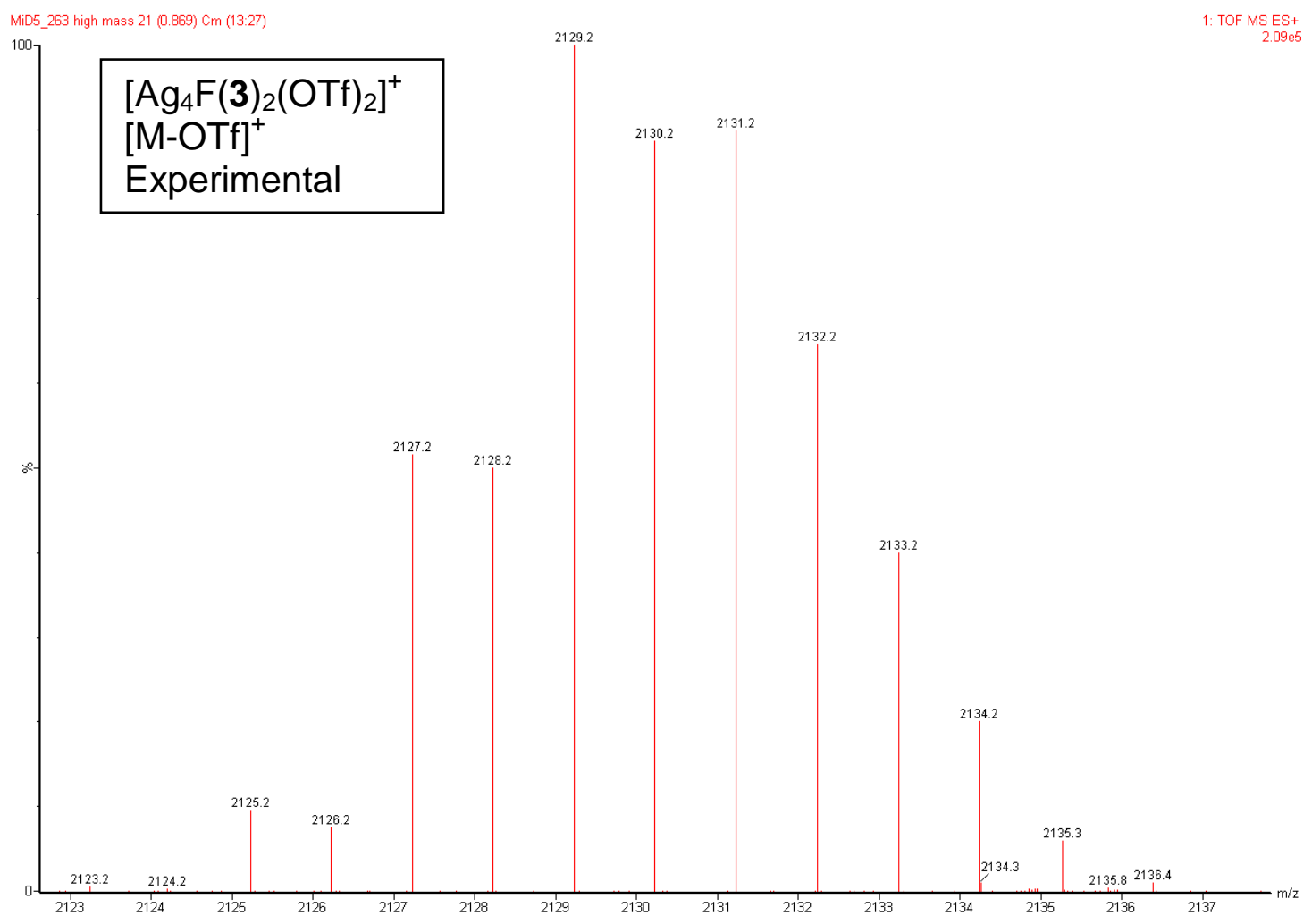

Figure S35: Mass spectrum (TOF-MS) peak corresponding to $\left[\mathrm{Ag}_{4} \mathrm{~F}(\mathbf{3})_{2}(\mathrm{OTf})_{2}\right]^{+}$.

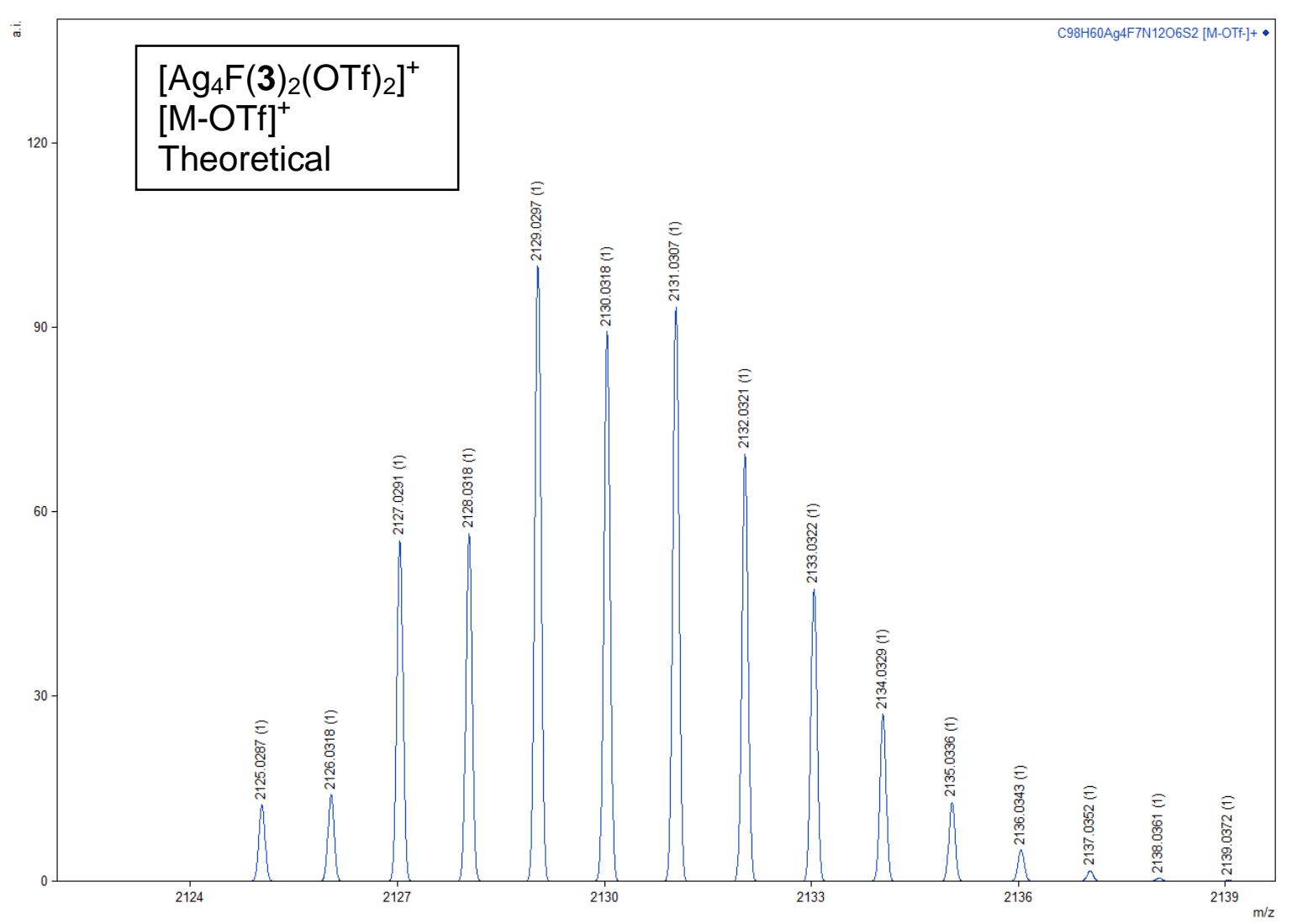

Figure S36: Simulated mass spectrum peak corresponding to $\left[\mathrm{Ag}_{4} \mathrm{~F}(\mathbf{3})_{2}(\mathrm{OTf})_{2}\right]^{+}$. 


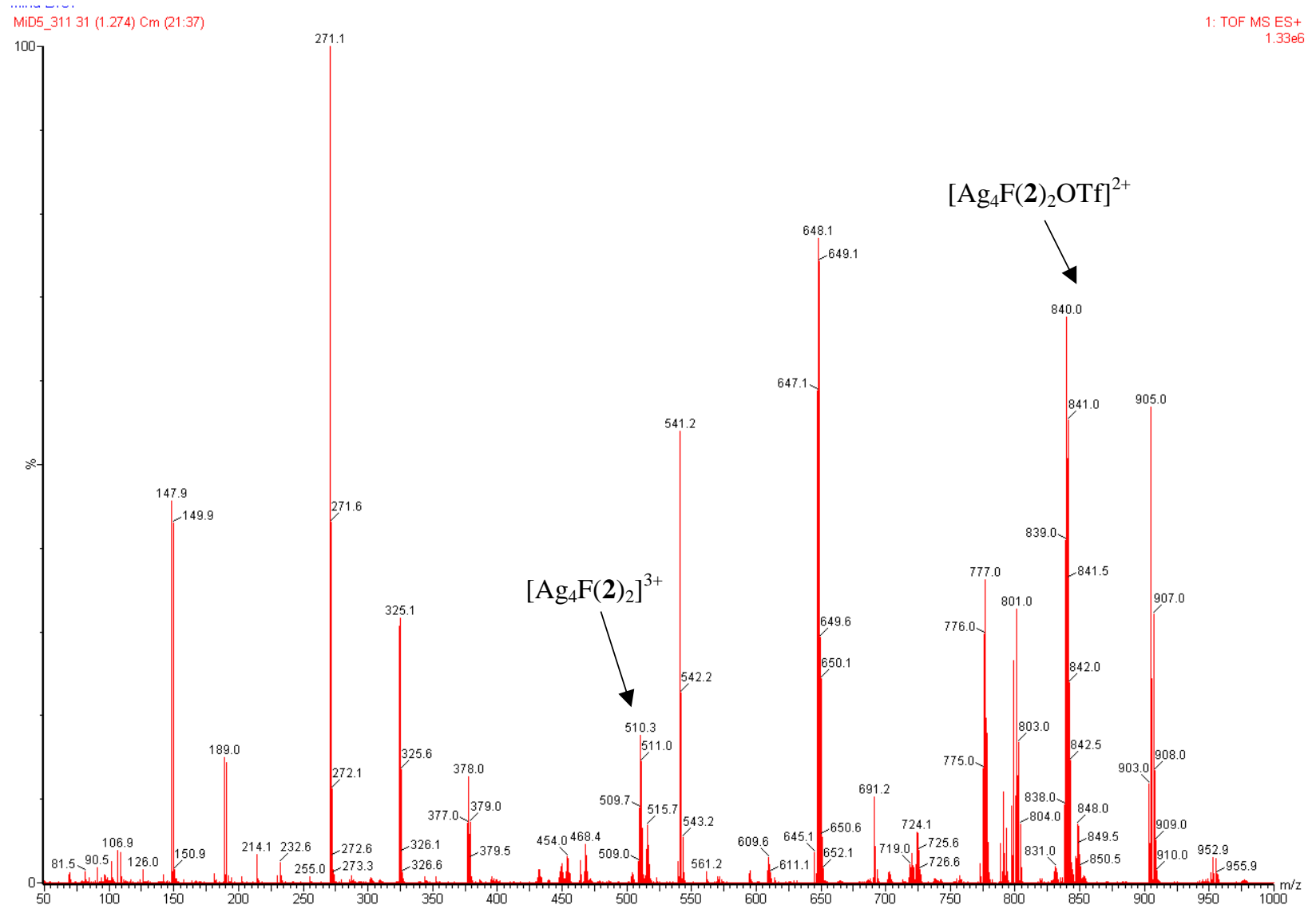

Figure S37: Mass spectrum (TOF-MS) of $\left[\mathrm{Ag}_{5} \mathrm{~F}(2)_{2}\right](\mathrm{OTf})_{4}$.

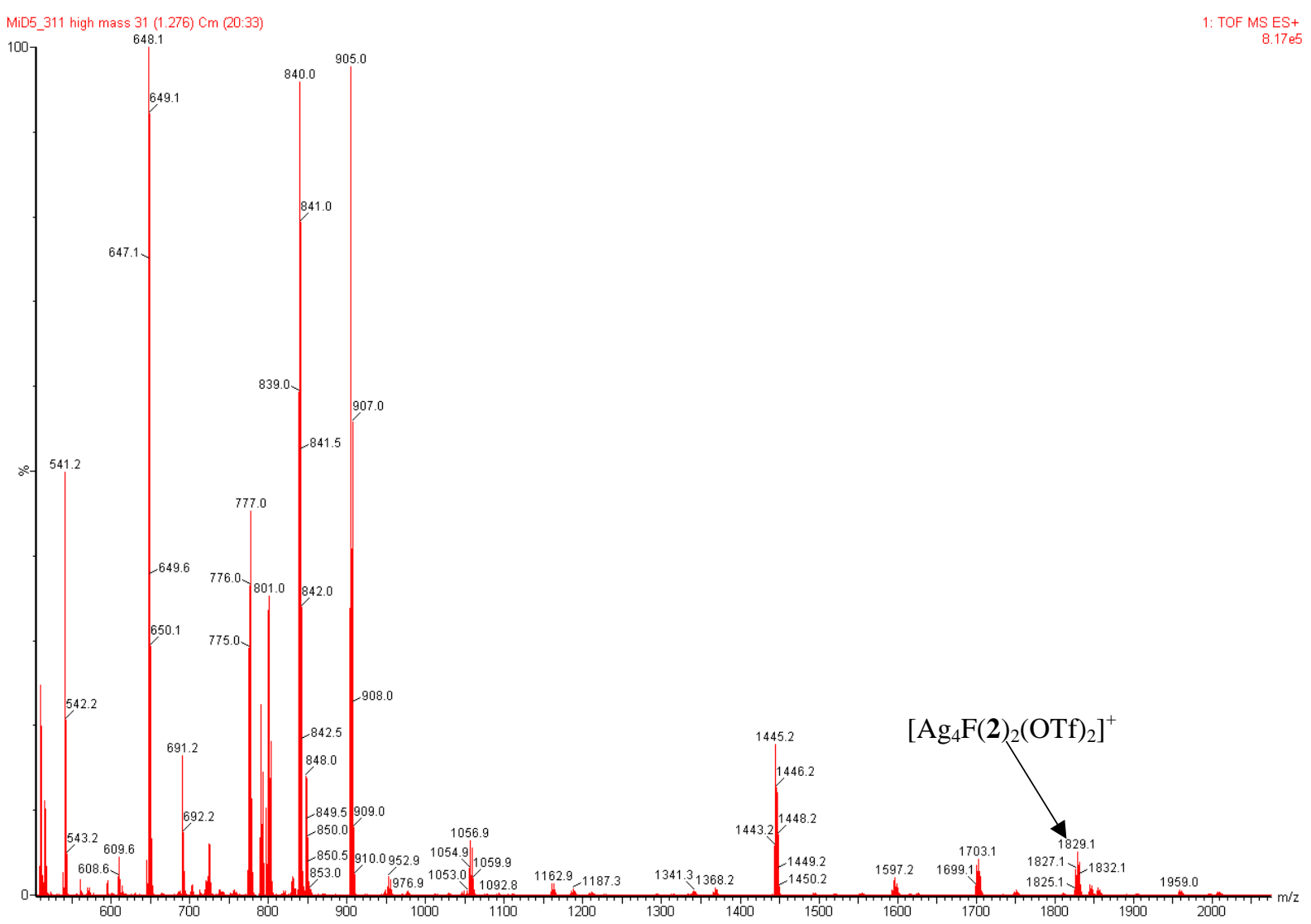

Figure S38: Mass spectrum (TOF-MS) of $\left[\mathrm{Ag}_{5} \mathrm{~F}(2)_{2}\right](\mathrm{OTf})_{4}$. 


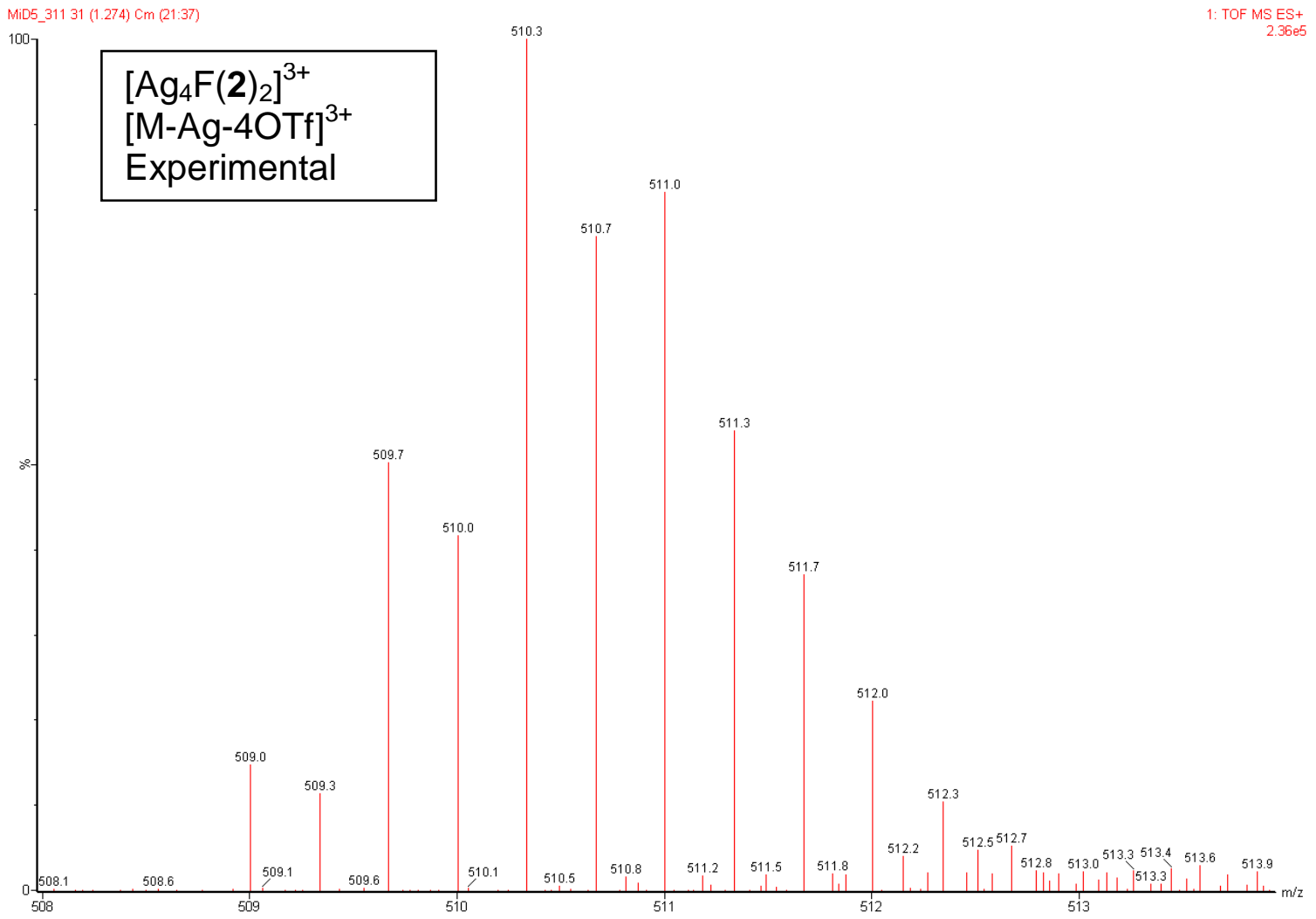

Figure S39: Mass spectrum (TOF-MS) peak corresponding to $\left[\mathrm{Ag}_{4} \mathrm{~F}(\mathbf{2})_{2}\right]^{3+}$ arising from $\left[\mathrm{Ag}_{5} \mathrm{~F}(\mathbf{2})_{2}\right]^{4+}$ after dissociation of one $\mathrm{Ag}(\mathrm{I})$ ion.

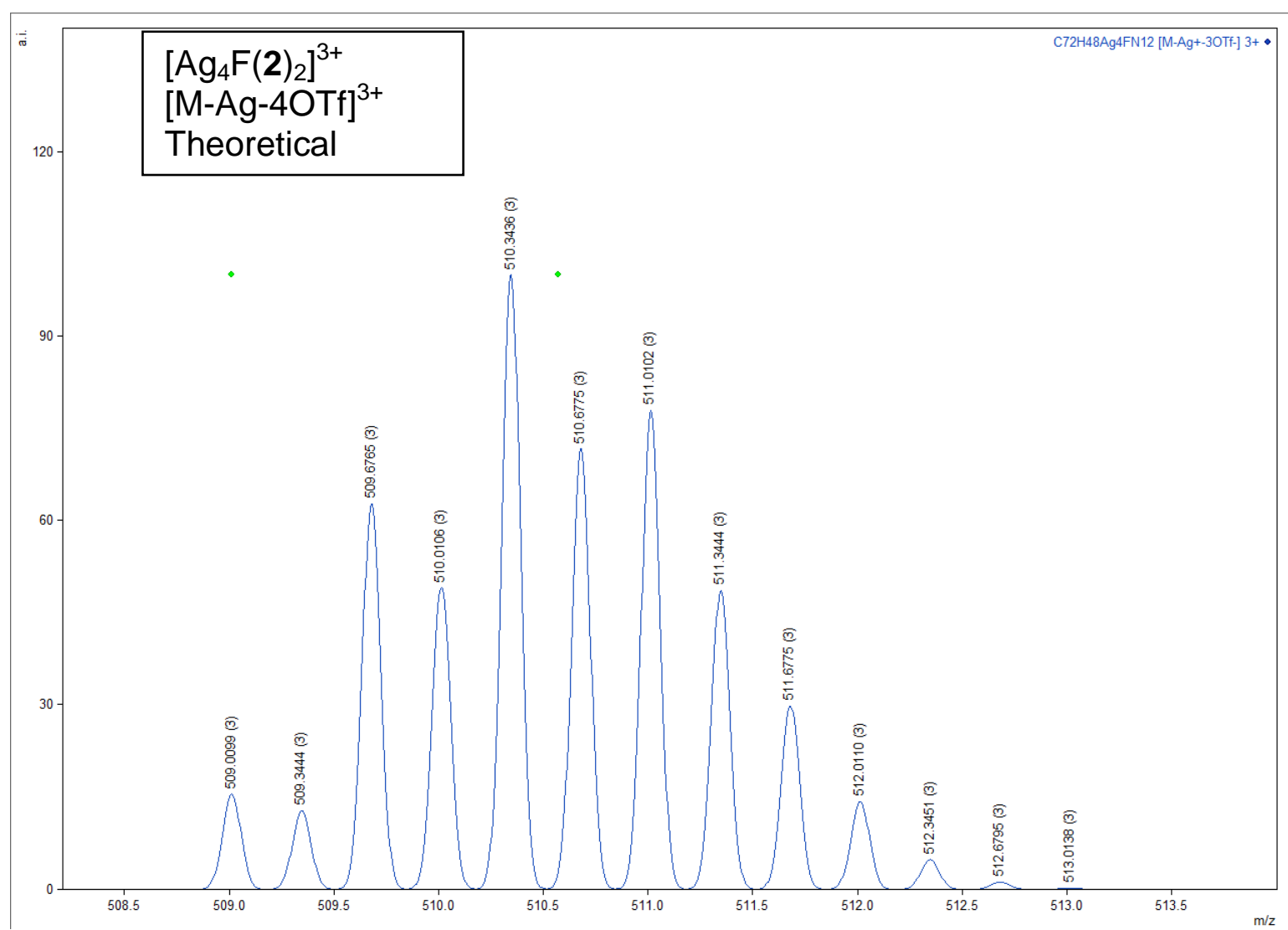

Figure S40: Simulated mass spectrum peak of $\left[\mathrm{Ag}_{4} \mathrm{~F}(2)_{2}\right]^{3+}$ 


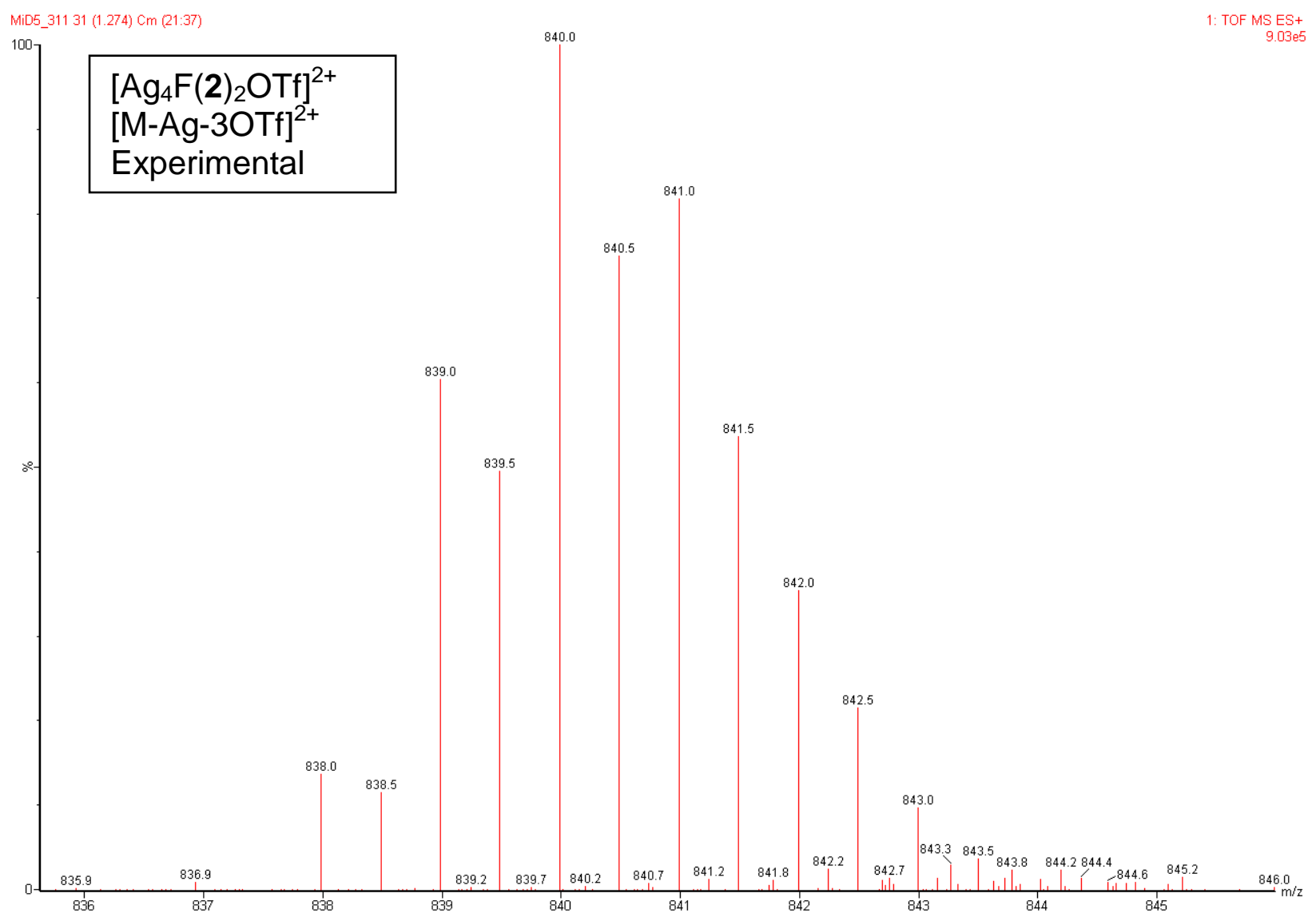

Figure S41: Mass spectrum (TOF-MS) peak corresponding to $\left[\mathrm{Ag}_{4} \mathrm{~F}(\mathbf{2})_{2} \mathrm{OTf}\right]^{2+}$ arising from $\left[\mathrm{Ag}_{5} \mathrm{~F}(\mathbf{2})_{2} \mathrm{OTf}\right]^{3+}$ after dissociation of one $\mathrm{Ag}(\mathrm{I})$ ion.

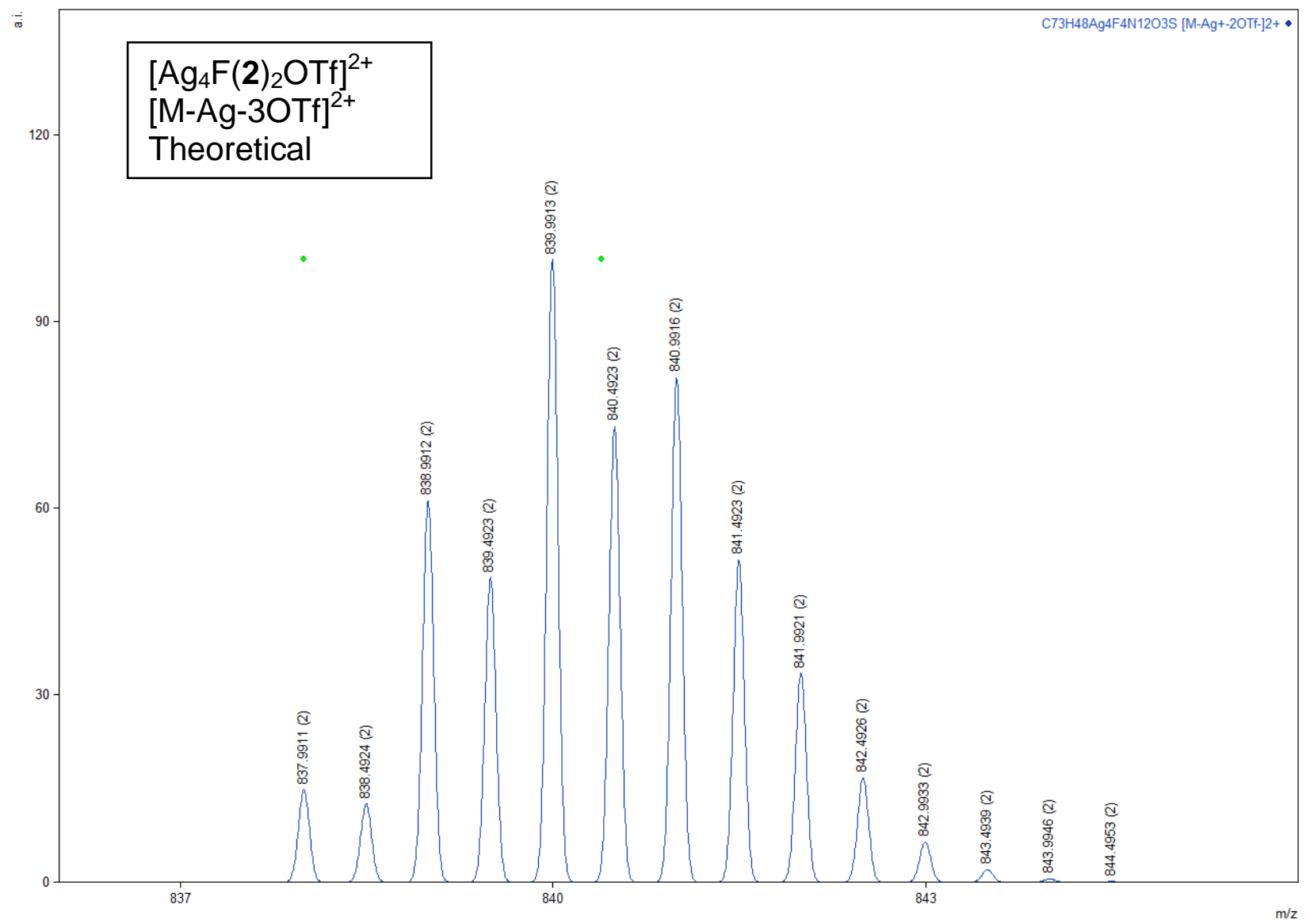

Figure S42: Simulated mass spectrum peak of $\left[\mathrm{Ag}_{4} \mathrm{~F}(2)_{2} \mathrm{OTf}\right]^{2+}$. 


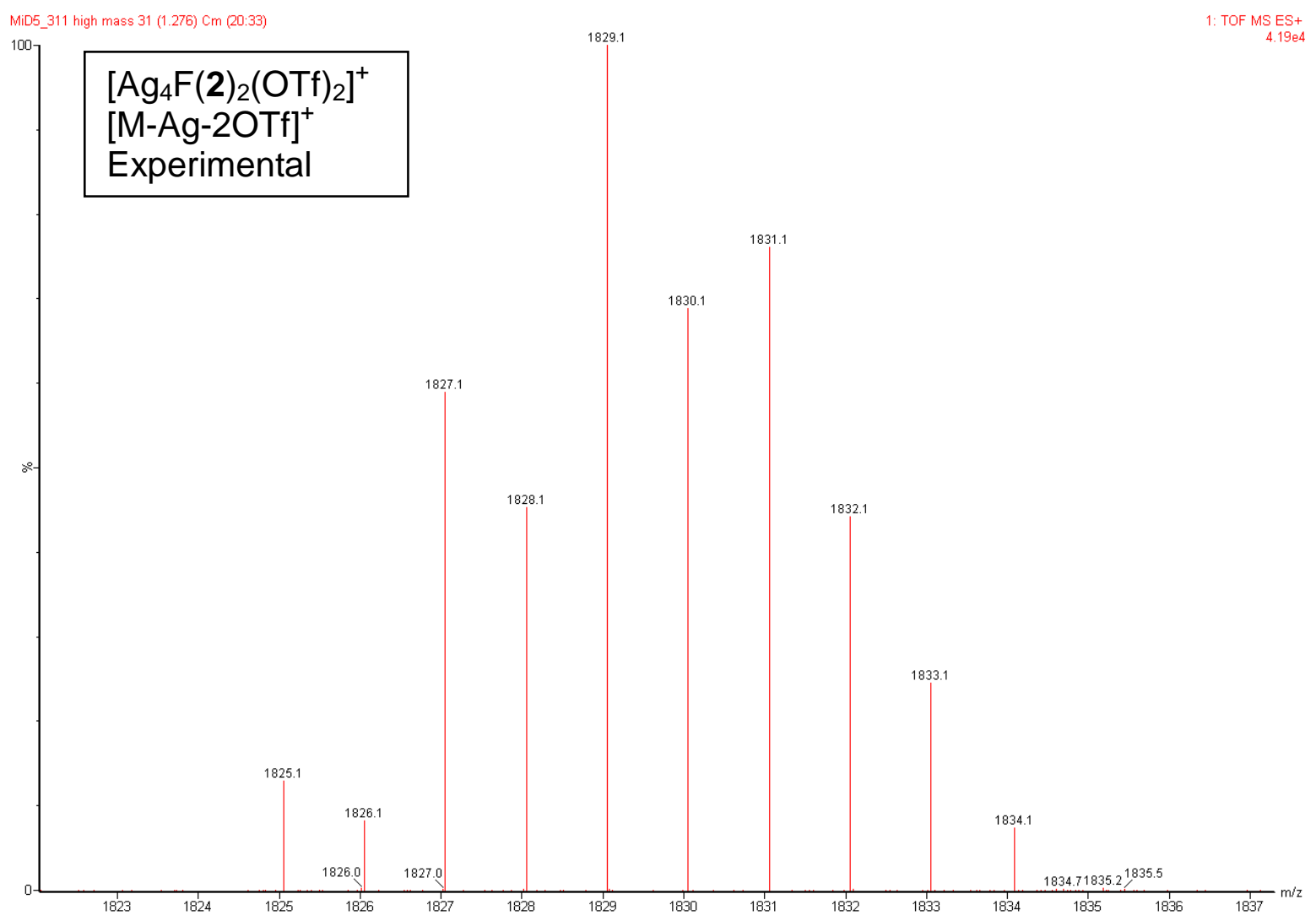

Figure S43: Mass spectrum (TOF-MS) peak corresponding to $\left[\mathrm{Ag}_{4} \mathrm{~F}(\mathbf{2})_{2}(\mathrm{OTf})_{2}\right]^{+}$arising from $\left[\mathrm{Ag}_{5} \mathrm{~F}(\mathbf{2})_{2}(\mathrm{OTf})_{2}\right]^{2+}$ after dissociation of one $\mathrm{Ag}(\mathrm{I})$ ion.

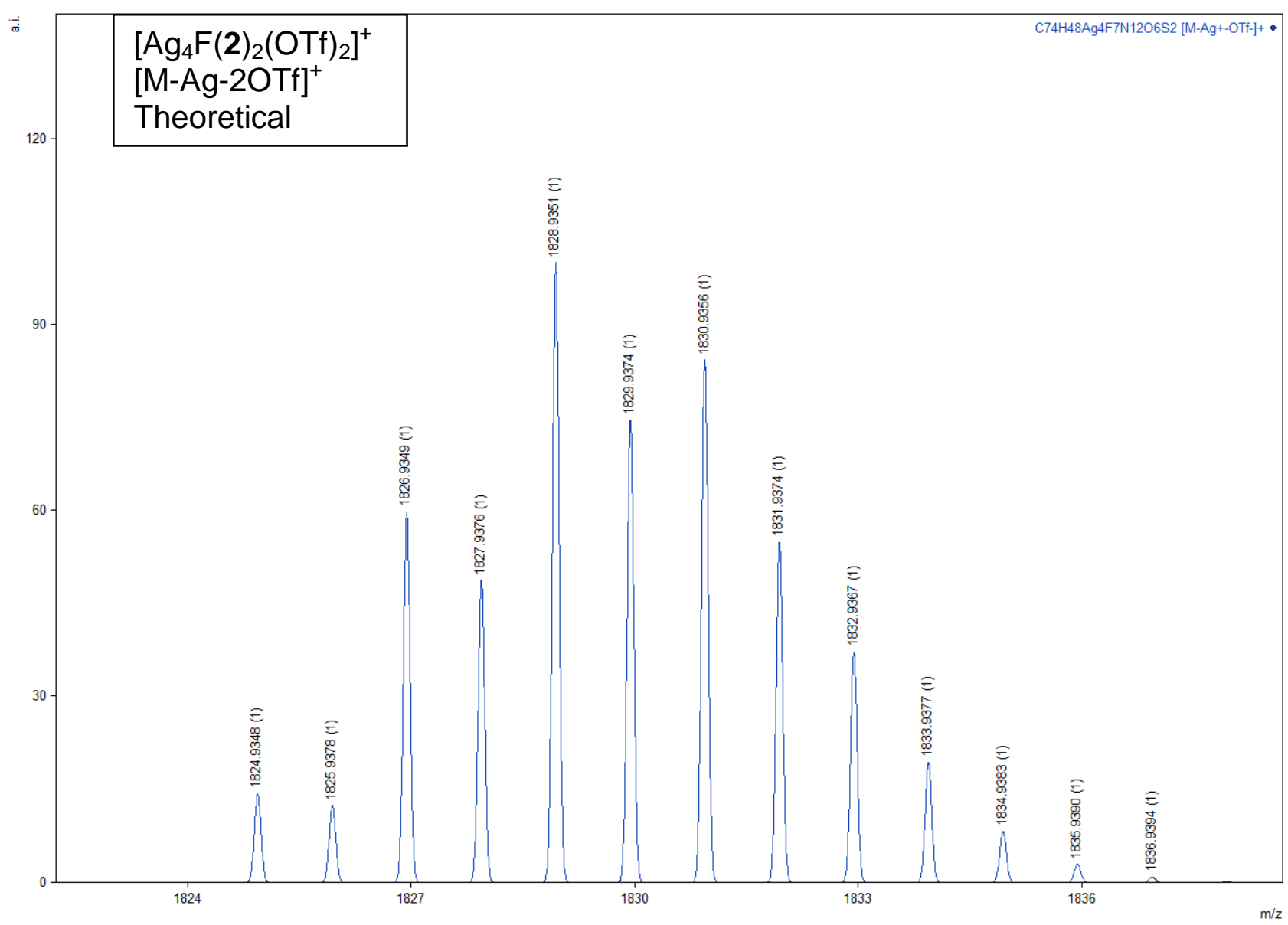

Figure S44: Simulated mass spectrum peak of $\left[\mathrm{Ag}_{4} \mathrm{~F}(2)_{2}(\mathrm{OTf})_{2}\right]^{+}$. 


\section{X-ray Crystallographic studies}

Crystal data for complexes $\left[\mathrm{Ag}_{4} \mathrm{~F}(\mathbf{2})_{2}\right](\mathrm{OTf})_{3}, \quad\left[\mathrm{Ag}_{4} \mathrm{~F}(\mathbf{3})_{2}\right](\mathrm{OTf})_{3} \cdot 3 \mathrm{H}_{2} \mathrm{O} \quad$ and $\left[\mathrm{Ag}_{5} \mathrm{~F}(2)_{2}\right](\mathrm{OTf})_{4} \cdot 2 \mathrm{H}_{2} \mathrm{O} \cdot \mathrm{C}_{3} \mathrm{H}_{6} \mathrm{O} \cdot \mathrm{C}_{6} \mathrm{H}_{6}$ were collected at $150 \mathrm{~K}$ on an Agilent Technologies SuperNova

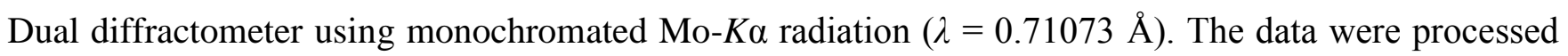
using CrysAlis Pro [3]. Structures were solved with the ShelXT [4] structure solution program using intrinsic phasing and refined by a full-matrix least-squares procedure based on $F^{2}$ with ShelXL [5] implemented in the $\mathrm{Olex}^{2}$ program suite [6]. All non-hydrogen atoms were readily located and refined anisotropically unless otherwise noted. Hydrogen atoms were initially located in the difference Fourier maps and were subsequently included in the model at geometrically calculated positions and refined by using a riding model unless otherwise noted. For $\left[\mathrm{Ag}_{4} \mathrm{~F}(\mathbf{2})_{2}\right](\mathrm{OTf})_{3}$ the complex cation was readily located and refined, however, only few atoms of the counterions were located having very large anisotropic displacement parameters and were in further steps of the refinement removed from the model. The scattering contributions of the disordered counterions were removed with a solvent mask procedure implemented in $\mathrm{Olex}^{2}$. The counterion contribution was not included in the reported molecular weight and density. Although the crystals were of low quality $\left(R_{\text {int }}=0.1833\right)$ the data were of sufficient quality to determine the structure of the complex cation. In the structure of $\left[\mathrm{Ag}_{4} \mathrm{~F}(3)_{2}\right](\mathrm{OTf})_{3} \cdot 3 \mathrm{H}_{2} \mathrm{O}$ hydrogen atoms on water oxygen atoms were not found in difference Fourier maps and were not included in the refinement. One water molecule and one triflate anion were disordered over a 2-fold rotation axis in the fixed ratio 0.50/0.50. Water molecules O8-O10 were refined with a fixed occupancy of 0.33 and restrained $U^{\mathrm{ij}}$ components. Hydrogen atoms attached to water molecules $\mathrm{O} 1$ and $\mathrm{O} 8-\mathrm{O} 10$ were not found in Fourier difference maps and were not included in the model. Crystals of $\left[\mathrm{Ag}_{5} \mathrm{~F}(2)_{2}\right](\mathrm{OTf})_{4} \cdot 2 \mathrm{H}_{2} \mathrm{O} \cdot \mathrm{C}_{3} \mathrm{H}_{6} \mathrm{O} \cdot \mathrm{C}_{6} \mathrm{H}_{6}$ were obtained by recrystallization from an acetone/benzene/ethyl acetate mixture and the crystal structure contains electron density that belongs to disordered solvate molecules. One triflate anion was refined by fixing the coordinates of C76 and O11, and restraining $U^{\mathrm{ij}}$ components for $\mathrm{O} 11, \mathrm{C} 76, \mathrm{~F} 12$ and F13. Benzene solvate molecule atoms C80-C85 were refined isotropically, and hydrogen atoms were not included in the model. Water molecules O14 and $\mathrm{O} 16$ were refined with a fixed occupancy ratio of 0.50 and restrained $U^{\mathrm{ij}}$ components. Hydrogen atoms attached to water molecules O14-O16 were not found in Fourier difference maps and were not included in the model. The scattering contributions of the disordered solvate molecules, including the unrecognized $\mathrm{C}_{4} \mathrm{O}_{2}$ fragment were removed with a solvent mask procedure implemented in Olex ${ }^{2}$. The unmodeled solvent contribution was not included in the reported molecular weight and density. Although the crystals were of low quality and the $w R_{2}$ value is 0.4596 , the data were of sufficient quality to determine the molecular and crystal structure. Details of the crystal, data collection and refinement parameters as well as selected bond distances and angles are given in Tables S1-S4. CCDC 1971156-1971158 contains the supplementary crystallographic data for this article. 
Table S1: Crystal data and structure refinement.

\begin{tabular}{|c|c|c|c|}
\hline Formula & {$\left[\mathrm{Ag}_{4} \mathrm{~F}(\mathbf{2})_{2}\right](\mathrm{OTf})_{3}$} & {$\left[\mathrm{Ag}_{4} \mathrm{~F}(\mathbf{3})_{2}\right](\mathrm{OTf})_{3} \cdot 3 \mathrm{H}_{2} \mathrm{O}$} & {$\left[\mathrm{Ag}_{5} \mathrm{~F}(\mathbf{2})_{2}\right](\mathrm{OTf})_{4} \cdot 2 \mathrm{H}_{2} \mathrm{O} \cdot \mathrm{C}_{3} \mathrm{H}_{6} \mathrm{O} \cdot \mathrm{C}_{6} \mathrm{H}_{6}$} \\
\hline Formula & $\mathrm{C}_{72} \mathrm{H}_{48} \mathrm{Ag}_{4} \mathrm{FN}_{12}$ & $\mathrm{C}_{99} \mathrm{H}_{66} \mathrm{Ag}_{4} \mathrm{~F}_{10} \mathrm{~N}_{12} \mathrm{O}_{12} \mathrm{~S}_{3}$ & $\mathrm{C}_{86} \mathrm{H}_{64} \mathrm{Ag}_{5} \mathrm{~F}_{13} \mathrm{~N}_{12} \mathrm{O}_{15} \mathrm{~S}_{4}$ \\
\hline$M_{\mathrm{r}}$ & 1531.70 & 2333.29 & 2420.08 \\
\hline$T(\mathrm{~K})$ & $150.00(10)$ & $150.00(10)$ & $150.00(10)$ \\
\hline Crystal system & Orthorhombic & Trigonal & Monoclinic \\
\hline Space group & Pnnn & $P 3_{2} 21$ & $P 2_{1} / n$ \\
\hline$a(\AA)$ & $12.0033(11)$ & $21.0986(6)$ & $16.2257(4)$ \\
\hline$b(\AA)$ & $16.0675(7)$ & $21.0986(6)$ & $27.2171(7)$ \\
\hline$c(\AA)$ & $19.9815(12)$ & $19.5901(5)$ & $22.3456(5)$ \\
\hline$\alpha\left(^{\circ}\right)$ & 90 & 90 & 90 \\
\hline$\beta\left(^{\circ}\right)$ & 90 & 90 & $90.166(2)$ \\
\hline$\gamma\left({ }^{\circ}\right)$ & 90 & 120 & 90 \\
\hline Volume $\left(\AA^{3}\right)$ & $3853.7(4)$ & $7552.2(5)$ & $9868.1(4)$ \\
\hline $\mathrm{Z}$ & 2 & 3 & 4 \\
\hline$D_{\mathrm{c}}\left(\mathrm{g} / \mathrm{cm}^{3}\right)$ & 1.320 & 1.539 & 1.629 \\
\hline$\mu\left(\mathrm{mm}^{-1}\right)$ & 1.048 & 0.912 & 1.149 \\
\hline$F(000)$ & 1522.0 & 3498.0 & 4800.0 \\
\hline Reflections collected & 42203 & 26760 & 88317 \\
\hline $\begin{array}{l}\text { Independent reflections } \\
\left(R_{\text {int }}\right)\end{array}$ & $5416(0.1833)$ & $11483(0.0250)$ & $22582(0.0732)$ \\
\hline $\begin{array}{l}\text { Data/restraints/parameter } \\
\mathrm{s}\end{array}$ & $5416 / 0 / 202$ & $11483 / 18 / 682$ & $22582 / 36 / 1182$ \\
\hline$R, w R_{2}[I>2 \sigma(I)]^{a}$ & $0.1339,0.3931$ & $0.0392,0.1018$ & $0.1609,0.4596$ \\
\hline$R, w R_{2}(\text { all data })^{a}$ & $0.1919,0.4347$ & $0.0489,0.1109$ & $0.1779,0.4742$ \\
\hline GOF, $S^{\mathrm{b}}$ & 1.234 & 1.023 & 1.908 \\
\hline $\begin{array}{l}\text { Largest diff. peak/hole / } \\
\mathrm{e} \AA^{-3}\end{array}$ & $2.06 /-1.78$ & $0.96 /-0.60$ & $2.09 /-2.48$ \\
\hline Flack parameter & l & $-0.028(8)$ & l \\
\hline
\end{tabular}
number of reflections and $p$ is the total number of parameters refined.

Table S2: Selected bond distances $(\AA)$ and angles $\left(^{\circ}\right)$ for $\left[\mathrm{Ag}_{4} \mathrm{~F}(\mathbf{2})_{2}\right](\mathrm{OTf})_{3}$.

\begin{tabular}{llll}
\hline Distance $(\AA)$ & & \\
\hline $\mathrm{Ag} 1-\mathrm{F} 1$ & $2.3204(8)$ & $\mathrm{Ag} 1-\mathrm{N} 3^{\mathrm{iii}}$ & $2.392(7)$ \\
$\mathrm{Ag} 1-\mathrm{N} 1$ & $2.427(8)$ & $\mathrm{Ag} 1 \cdots \mathrm{Ag} 1^{\mathrm{i}}$ & $3.366(2)$ \\
$\mathrm{Ag} 1-\mathrm{N} 2^{\mathrm{i}}$ & $2.216(6)$ & $\mathrm{Ag} 1 \cdots \mathrm{Ag} 1^{\mathrm{ii}}$ & $3.195(2)$ \\
$\mathrm{Angle}\left({ }^{\circ}\right)$ & & & \\
\hline $\mathrm{F} 1-\mathrm{Ag} 1-\mathrm{N} 1$ & $105.59(17)$ & $\mathrm{N}^{\mathrm{iii}}-\mathrm{Ag} 1-\mathrm{N} 1$ & $81.6(3)$ \\
$\mathrm{F} 1-\mathrm{Ag} 1-\mathrm{N} 3^{\mathrm{iii}}$ & $106.96(18)$ & $\mathrm{Ag} 1-\mathrm{F} 1-\mathrm{Ag} 1^{\mathrm{iii}}$ & $179.33(3)$ \\
$\mathrm{N} 2^{\mathrm{ii}}-\mathrm{Ag} 1-\mathrm{F} 1$ & $121.1(2)$ & $\mathrm{Ag} 1-\mathrm{F} 1-\mathrm{Ag} 1^{\mathrm{ii}}$ & $93.00(6)$ \\
$\mathrm{N} 2^{\mathrm{ii}}-\mathrm{Ag} 1-\mathrm{N} 1$ & $116.2(3)$ & $\mathrm{Ag} 1-\mathrm{F} 1-\mathrm{Ag} 1^{\mathrm{i}}$ & $87.00(6)$ \\
$\mathrm{N} 2^{\mathrm{ii}}-\mathrm{Ag} 1-\mathrm{N} 3^{\mathrm{iii}}$ & $118.2(2)$ & & \\
\hline
\end{tabular}

Symmetry codes: (i) $x, 1 / 2-y, 3 / 2-z$; (ii) $1 / 2-x, 1 / 2-y, z$; (iii) $1 / 2-x, y, 3 / 2-z$. 
Table S3: Selected bond distances $(\AA)$ and angles $\left(^{\circ}\right)$ for $\left[\mathrm{Ag}_{4} \mathrm{~F}(\mathbf{3})_{2}\right](\mathrm{OTf})_{3} \cdot 3 \mathrm{H}_{2} \mathrm{O}$.

\begin{tabular}{llll}
\hline Distance $(\AA)$ & & & \\
\hline $\mathrm{Ag} 1-\mathrm{F} 1$ & $2.351(3)$ & $\mathrm{Ag} 2-\mathrm{N} 3$ & $2.249(5)$ \\
$\mathrm{Ag} 2-\mathrm{F} 1$ & $2.413(3)$ & $\mathrm{Ag} 2-\mathrm{N} 4^{\mathrm{i}}$ & $2.314(5)$ \\
$\mathrm{Ag} 1-\mathrm{N} 1$ & $2.375(5)$ & $\mathrm{Ag} 2-\mathrm{N} 5^{\mathrm{i}}$ & $2.491(5)$ \\
$\mathrm{Ag} 1-\mathrm{N} 2$ & $2.525(5)$ & $\mathrm{Ag} 1 \cdots \mathrm{Ag} 1^{\mathrm{i}}$ & $3.1171(9)$ \\
$\mathrm{Ag} 1-\mathrm{N} 6^{\mathrm{i}}$ & $2.242(4)$ & $\mathrm{Ag} 2 \cdots \mathrm{Ag}^{\mathrm{i}}$ & $3.2036(9)$ \\
& & & \\
Angle $\left(^{\circ}\right)$ & & & \\
\hline $\mathrm{F} 1-\mathrm{Ag} 1-\mathrm{N} 1$ & $107.00(12)$ & $\mathrm{N} 3-\mathrm{Ag} 2-\mathrm{N} 4^{\mathrm{i}}$ & $129.63(19)$ \\
$\mathrm{F} 1-\mathrm{Ag} 1-\mathrm{N} 2$ & $103.74(12)$ & $\mathrm{N} 3-\mathrm{Ag} 2-\mathrm{N} 5^{\mathrm{i}}$ & $109.76(17)$ \\
$\mathrm{N} 1-\mathrm{Ag} 1-\mathrm{N} 2$ & $87.97(15)$ & $\mathrm{N} 4^{\mathrm{i}}-\mathrm{Ag} 2-\mathrm{F} 1$ & $107.82(13)$ \\
$\mathrm{N} 6^{\mathrm{i}}-\mathrm{Ag} 1-\mathrm{F} 1$ & $121.23(12)$ & $\mathrm{N} 4^{\mathrm{i}}-\mathrm{Ag} 2-\mathrm{N} 5^{\mathrm{i}}$ & $81.81(17)$ \\
$\mathrm{N} 6^{\mathrm{i}}-\mathrm{Ag} 1-\mathrm{N} 1$ & $122.25(17)$ & $\mathrm{Ag} 1-\mathrm{F} 1-\mathrm{Ag} 1^{\mathrm{i}}$ & $83.05(14)$ \\
$\mathrm{N} 6^{\mathrm{i}}-\mathrm{Ag} 1-\mathrm{N} 2$ & $107.72(15)$ & $\mathrm{Ag} 1-\mathrm{F} 1-\mathrm{Ag} 2^{\mathrm{i}}$ & $175.443(16)$ \\
$\mathrm{F} 1-\mathrm{Ag} 2-\mathrm{N} 5^{\mathrm{i}}$ & $110.38(14)$ & $\mathrm{Ag} 1-\mathrm{F} 1-\mathrm{Ag} 2$ & $97.068(17)$ \\
$\mathrm{N} 3-\mathrm{Ag} 2-\mathrm{F} 1$ & $112.60(12)$ & $\mathrm{Ag} 2^{\mathrm{i}}-\mathrm{F} 1-\mathrm{Ag} 2$ & $83.18(14)$ \\
\hline
\end{tabular}

Symmetry code: (i) $y, x, 1-z$.

Table S4: Selected bond distances $(\AA)$ and angles $\left(^{\circ}\right)$ for $\left[\mathrm{Ag}_{5} \mathrm{~F}(\mathbf{2})_{2}\right](\mathrm{OTf})_{4} \cdot 2 \mathrm{H}_{2} \mathrm{O} \cdot \mathrm{C}_{3} \mathrm{H}_{6} \mathrm{O} \cdot \mathrm{C}_{6} \mathrm{H}_{6}$.

\begin{tabular}{|c|c|c|c|}
\hline \multicolumn{4}{|l|}{ Distance $(\AA)$} \\
\hline Ag1-F1 & $2.463(6)$ & Ag4-F1 & $2.397(7)$ \\
\hline Ag1-N1 & $2.263(9)$ & Ag4-N4 & $2.248(11)$ \\
\hline Ag1-N7 & $2.254(9)$ & Ag4-N11 & $2.223(10)$ \\
\hline Ag2-F1 & $2.575(7)$ & Ag5-N5 & $2.436(11)$ \\
\hline Ag2-N2 & $2.201(9)$ & Ag5-N6 & $2.294(11)$ \\
\hline Ag2-N8 & $2.294(10)$ & Ag5-N12 & $2.215(10)$ \\
\hline Ag2-N9 & $2.492(11)$ & $\operatorname{Ag} 1 \cdots \operatorname{Ag} 2$ & $2.9388(14)$ \\
\hline Ag3-F1 & $2.500(6)$ & $\operatorname{Ag} 1 \cdots \operatorname{Ag} 5$ & $3.0845(16)$ \\
\hline Ag3-N3 & $2.235(10)$ & Ag $2 \cdots A g 3$ & $2.9589(19)$ \\
\hline Ag3-N9 & $2.498(11)$ & $\mathrm{Ag} 3 \cdots \mathrm{Ag} 4$ & $2.9735(16)$ \\
\hline Ag3-N10 & $2.306(11)$ & Ag $4 \cdots A g 5$ & $2.9433(15)$ \\
\hline \multicolumn{4}{|l|}{ Angle $\left(^{\circ}\right)$} \\
\hline N1-Ag1-F1 & $110.0(3)$ & N10-Ag3-N9 & $86.2(4)$ \\
\hline N7-Ag1-F1 & $117.5(3)$ & N4-Ag4-F1 & $113.7(3)$ \\
\hline N7-Ag1-N1 & 131.1(4) & N11-Ag4-F1 & $121.0(3)$ \\
\hline N2-Ag2-F1 & $119.0(3)$ & N11-Ag4-N4 & $123.8(4)$ \\
\hline $\mathrm{N} 2-\mathrm{Ag} 2-\mathrm{N} 8$ & $133.3(4)$ & N6-Ag5-N5 & $90.3(4)$ \\
\hline N2-Ag2-N9 & $115.5(4)$ & N12-Ag5-N5 & $123.8(4)$ \\
\hline N8-Ag2-F1 & $100.0(3)$ & N12-Ag5-N6 & $128.0(4)$ \\
\hline N8-Ag2-N9 & $86.4(4)$ & Ag1-F1-Ag2 & $71.34(18)$ \\
\hline N9-Ag2-F1 & $91.0(3)$ & Ag1-F1-Ag3 & $142.6(3)$ \\
\hline N3-Ag3-F1 & $120.6(3)$ & Ag3-F1-Ag2 & $71.32(18)$ \\
\hline N3-Ag3-N9 & $114.5(4)$ & $\mathrm{Ag} 4-\mathrm{F} 1-\mathrm{Ag} 1$ & $142.6(3)$ \\
\hline N3-Ag3-N10 & $124.1(4)$ & Ag4-F1-Ag2 & $146.0(3)$ \\
\hline N9-Ag3-F1 & $92.6(3)$ & $\mathrm{Ag} 4-\mathrm{F} 1-\mathrm{Ag} 3$ & $74.75(18)$ \\
\hline N10-Ag3-F1 & $108.6(3)$ & & \\
\hline
\end{tabular}




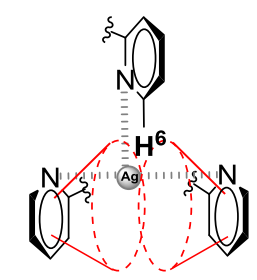

Figure S45: Schematic presentation of the shielding cones of the pyridine rings.

\section{References}

[1] Drev, M.; Grošelj, U.; Ledinek, B.; Perdih, F.; Svete, J.; Štefane B.; Požgan F. Org. Lett. 2018, 20 (17), $5268-5273$.

[2] Farley, S. J.; Rochester, D. L.; Thompson, A. L.; Howard, J. A. K.; Williams, J. A. G. Inorg. Chem. 2005, 44 (26), 9690-9703.

[3] CrysAlisPro, version 1.171.38.46; Rigaku Oxford Diffraction: Yarnton, UK, 2018.

[4] Sheldrick, G. M. Acta Cryst. 2015, A71, 3-8.

[5] Sheldrick, G. M. Acta Cryst. 2015, C71, 3-8.

[6] Dolomanov, O. V.; Bourhis, L. J.; Gildea, R. J.; Howard J. A. K.; Puschmann H. J. Appl. Crystallogr. 2009, 42, 339-341. 